FÁBIO DE CARVALHo GROFF

\title{
FUNDAMENTO DO DIREITO DO INVENTOR: PERSPECTIVA HISTÓRICA BRASILEIRA
}

\author{
Tese de Doutorado
}

Orientador: Prof. TITUlaR IGNACIO M. POVEDA Velasco

\author{
Universidade de São Paulo
}

Faculdade de Direito do Largo de São Francisco

São Paulo, janeiro de 2014 
A meus pais, em especial a Jácomo Osmar Groff, tirado que foi de nosso convívio enquanto este trabalho era realizado 
BANCA EXAMINADORA:

Prof. Titular Ignacio M. Poveda Velasco (Presidente)

Prof. Dr. NEWTON SILVEIRA

Prof. Dr. José CARlos TinOCO SOARES

Profa. Dra. MARIA CRISTINA DA SILVA CARMIGNANI

Prof. Dr. LuCIANO DE CAMARgo PENTEADO 


\section{TÁbUA de Abreviaturas}

- ANRJ - Arquivo Nacional do Rio de Janeiro

- Art.; arts. - artigo; artigos (de acordo com a Lei Complementar 95, de 26 de fevereiro de 1998, art. 10, I)

- BGD - Brazilian Government Documents (arquivos do Center for Research Libraries CRL - http://www.crl.edu/brazil)

- BN - Biblioteca Nacional

- Cap. - Capítulo

- Cf. - conferir; confrontar

- cit. - citado; citada

- CUP - Convenção da União de Paris

- D. - Digesta

- DBB - Endereço eletrônico oficial do Professor Denis Borges Barbosa e repositório de documentos históricos (http://denisbarbosa.addr.com)

- et al. - et alli (e outros)

- FSP - Folha de São Paulo

- G. - Gai Institutiones

- INPI - Instituto Nacional da Propriedade Industrial

- JB - Jornal do Brasil

- Min. - Ministro, Ministra

- MommSen-Krüger - Mommsen, Theodor; KrÜGER, Paul, Corpus Iuris Civilis, 4. ed., Berlin, Weidmann, 1886

- OMPI - Organização Mundial da Propriedade Intelectual 
- op.cit. - Obra citada

- p. - página; páginas

• pr. - principium, proêmio

- RABPI - Revista da Associação Brasileira da Propriedade Intelectual (Rio de Janeiro)

- RHBN - Revista de História da Biblioteca Nacional (Rio de Janeiro)

- RT - Editora Revista dos Tribunais (São Paulo)

- $\boldsymbol{R} \boldsymbol{T}$ - Revista dos Tribunais (Periódico - São Paulo)

- t. - tomo

- V. (ou v.) - ver; vide

• v.g. - "Verbi Gratia"

- Vol. - volume

- Watson's DigeST - Watson, Alan (org.), The Digest of Justinian, 2. ed., Philadelphia, University of Pennsylvania Press, 1998

- WIPO - World Intellectual Property Organization (v. OMPI) 


\section{SUMÁRIO}

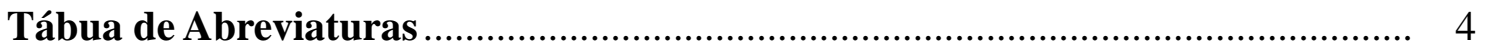

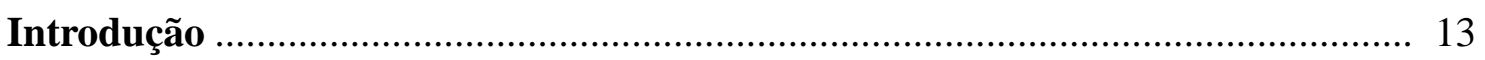

1. A inventividade no Brasil e o direito do inventor .................................................. 13

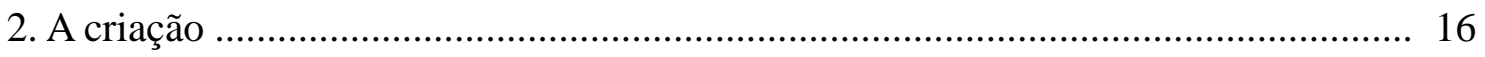

3. O precoce envolvimento brasileiro com normas de proteção ao

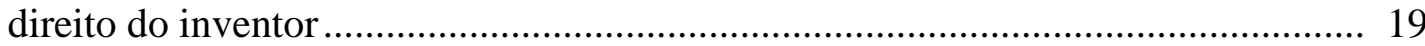

4. Os requisitos atuais para a obtenção de patentes: novidade, atividade inventiva e aplicação industrial ....................................................................... 20

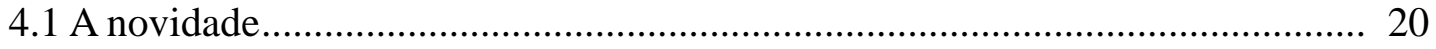

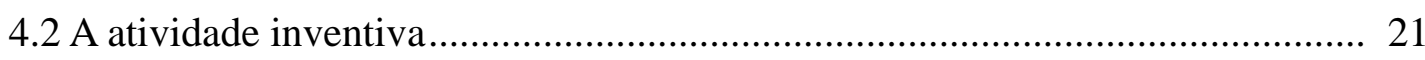

4.3 A aplicação industrial .............................................................................. 21

$4.4 \mathrm{O}$ fenômeno da sociedade do conhecimento .................................................. 22

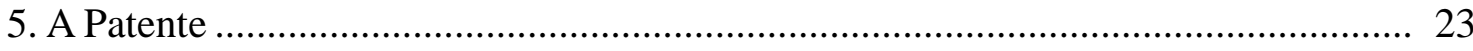

5.1 Diferença entre descoberta e invenção....................................................... 24

5.2 Da exclusividade, ou "direito de exclusiva" .................................................. 25

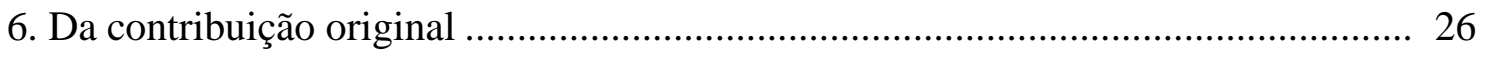

7. Da divisão do trabalho em partes ................................................................... 26

Notas Sobre a Metodologia Adotada .......................................................................

\section{PARTe I \\ Perspectiva Histórica Brasileira}

Capítulo I - A fonte original: o Alvará de 28 de abril de 1809

Erro! Indicador $n$

1. Momento histórico Erro! Indicador n

2. Breve sinopse da origem das patentes de invenção Erro! Indicador $n$

$2.1 \mathrm{O}$ motivo da escolha do tema Erro! Indicador n

2.2 Teorias das origens Erro! Indicador $n$

2.3 O Renascimento Erro! Indicador n

2.4 A primeira patente e a "parte veneziana" Erro! Indicador $n$

$2.5 \mathrm{O}$ sistema inglês Erro! Indicador $\mathbf{n}$

3. Motivos para a promulgação do Alvará - a busca da ratio legis Erro! Indicador $n$ 
3.1 A Convenção Secreta de 1807 e a posterior revogação do Alvará de 05 de janeiro de 1785

Erro! Indicador $n$

3.2 A semelhança com o Statute of Monopolies.

Erro! Indicador $n$

3.3 A guerra contra Napoleão

Erro! Indicador $n$

3.4 Proposição divergente

Erro! Indicador $n$

3.5 Conclusão

Erro! Indicador $n$

4. Cria-se a Real Junta de Comércio

Erro! Indicador $n$

5. Características do Alvará

Erro! Indicador $n$

5.1 A concessão de privilégios

Erro! Indicador $n$

$5.2 \mathrm{O}$ prazo de quatorze anos e exceções

Erro! Indicador n

5.3 A instalação de fábricas e o empreendimento de indústrias novas

Erro! Indicador $n$

6. Dos requisitos para a concessão do privilégio

Erro! Indicador $n$

6.1 Considerações gerais.....

Erro! Indicador $n$

6.2 O requisito de "Novidade"

Erro! Indicador $n$

$6.3 \mathrm{~A}$ "Verdade"

Erro! Indicador $n$

$6.4 \mathrm{O}$ "Fundamento"

Erro! Indicador $n$

7. A utilização prática do $\S 6 .^{\circ}$ do Alvará

Erro! Indicador $n$

8. Direito do Inventor

Erro! Indicador $n$

Capítulo II - A Independência e a Lei de 28 de Agosto de 1830

Erro! Indicador $n$

1. O retorno de D. João a Portugal e a posterior emancipação

Erro! Indicador $n$

2. A Constituição de 1824

Erro! Indicador $n$

3. A Lei de 28 de Agosto de 1830

Erro! Indicador $n$

3.1 Razões possíveis para a elaboração da Lei

Erro! Indicador $n$

3.1.1 Aniquilação de corpos municipais

Erro! Indicador $n$

3.1.2 As Corporações de Ofícios

Erro! Indicador $n$

3.1.3 As discussões sobre o projeto

Erro! Indicador $\mathbf{n}$

3.2 Análise dos dispositivos da Lei

Erro! Indicador $n$

4. Fundamento do direito do inventor.

Erro! Indicador $n$

5. Requisitos da patente de invenção

Erro! Indicador $n$

5.1 Requisitos prévios

Erro! Indicador $n$

5.1.1 Da "utilidade"

Erro! Indicador $n$ 
5.1.3 Da ausência do requisito de "novidade" no texto da Lei hipóteses de interpretação Erro! Indicador $n$

5.2 Requisitos de manutenção

Erro! Indicador $n$

6. A maior contribuição da Lei: a definição da natureza do direito

Erro! Indicador $n$

Capítulo III - A Lei 3.129, de 14 de outubro de 1882, e o ingresso do Brasil na Convenção da União de Paris

Erro! Indicador $n$

1. Os relatórios ministeriais Erro! Indicador $n$

2. As invenções e os direitos dela recorrentes têm caráter internacional Erro! Indicador $n$

3. O Advento das Exposições Universais Erro! Indicador $n$

4. A Primeira Conferência: Viena, 1873

Erro! Indicador $n$

5. Resultados do Congresso Internacional sobre Propriedade Industrial, de 1878

Erro! Indicador $n$

6. A Lei 3.129 , de 14 de outubro de 1882

Erro! Indicador $n$

6.1 Considerações gerais sobre a abordagem histórica dos antecedentes da norma

Erro! Indicador $n$

6.2 O início dos debates sobre o tema na Câmara.

Erro! Indicador $n$

6.3 A proposição de Buarque de Macedo

Erro! Indicador $n$

6.4 O substitutivo de Theodoreto Souto

Erro! Indicador $n$

6.5 Entrementes, ocorre a Conferência Internacional de Paris em 1880 e o CONDE DE VILLENEUVE entrega novo relatório

Erro! Indicador $n$

6.5.1 Os princípios descritos no relatório de VILLENEUVE

ERRO! INDICADOR

6.6 A sequência do andamento do projeto de reforma da lei sobre invenções.....

Erro! Indicador $n$

6.7 O trâmite no Senado

Erro! Indicador $n$

6.8 Ilações sobre os motivos para o ingresso brasileiro na Convenção da União de Paris

Erro! Indicador $n$

6.9 Estudo sobre a Lei 3.129/1882 em conjunto com seu regulamento: o Decreto 8.820 , de 30 de dezembro de 1882

Erro! Indicador $n$

6.9.1 Garantia da propriedade e definições - a interpretação autêntica contida no Decreto

Erro! Indicador n

6.9.2 O pedido internacional

Erro! Indicador n

6.9.3 Conceito de inventor e outras disposições

Erro! Indicador n

6.9.4 A propriedade e sua natureza

Erro! Indicador $\mathbf{n}$ 
6.9.5 O prazo de duração, propriedade conjunta e atos de disposição

Erro! Indicador n

6.9.6 Desapropriação

Erro! Indicador $n$

6.9.7 Pedidos simultâneos

Erro! Indicador $n$

6.9.8 A Jurisdição Comercial

Erro! Indicador $\mathbf{n}$

6.9.9 Formalidades

Erro! Indicador n

6.9.10 Do exame prévio e secreto

Erro! Indicador $\mathbf{n}$

6.9.11 Da Garantia provisória, emolumentos e outras despesas

Erro! Indicador $\mathbf{n}$

6.9.12 Da expedição da patente.

Erro! Indicador $n$

6.9.12.1 Breve reflexão sobre os diversos modelos de deferimento de patentes

Erro! Indicador $n$

6.9.12.2 A Exceção da Lei 3.674/1919

Erro! Indicador $n$

6.9.13 Da Extinção das Patentes

Erro! Indicador $n$

6.9.14 Disposições finais da Lei e do Decreto

Erro! Indicador $\mathbf{n}$

7. A doutrina

Erro! Indicador $n$

7.1 Debates preliminares sobre a natureza do direito do inventor

Erro! Indicador $n$

7.2 Teorias sobre a propriedade imaterial

Erro! Indicador $n$

7.2.1 Teoria do privilégio

Erro! Indicador $\mathbf{n}$

7.2.2 Teoria do contrato tácito

Erro! Indicador $n$

7.2.3 Teorias de direito pessoal

Erro! Indicador $n$

7.2.4 Teorias de direito patrimonial

Erro! Indicador $n$

7.2.5 A teoria intermediária

Erro! Indicador $n$

7.2.6 A proposição por uma nova divisão de direitos.

Erro! Indicador $n$

7.2.7 Propriedade ou direito de natureza especial?

Erro! Indicador $n$

7.2.8 Crítica à doutrina de J. GAMA CERQUEIRA e conclusão do tópico

Erro! Indicador $n$

8. As decorrências do debate no Projeto de Código Civil

Erro! Indicador $n$

9. A invenção como objeto de domínio - a doutrina de JOSÉ DE ALENCAR

ERRO! INDICADOR

Capítulo IV - A República e os Códigos da Propriedade Industrial

.Erro! Indicador $\mathbf{n}$

1. Pleitos de unificação da Propriedade Industrial

Erro! Indicador $n$

2. A Diretoria Geral da Propriedade Industrial

Erro! Indicador $n$ 
2.1 A explicação para a mudança

Erro! Indicador $n$

3. A melhoria da "máquina"

Erro! Indicador $n$

4. O anúncio da reforma legislativa

Erro! Indicador $n$

5. O projeto

Erro! Indicador $n$

6. O Código da Propriedade Industrial de 1945.

Erro! Indicador $n$

6.1 A quem a lei autorizava fazer o pedido

Erro! Indicador $\mathbf{n}$

6.2 Os pedidos estrangeiros

Erro! Indicador $n$

6.3 Titularidade

Erro! Indicador $n$

6.4 Os direitos do inventor

Erro! Indicador $n$

6.5 Da patente

Erro! Indicador $n$

6.6 A teoria do direito formativo gerador, ou direito aquisitivo gerador - nascimento do Direito de Propriedade Industrial.

Erro! Indicador $n$

6.7 Natureza do direito

Erro! Indicador $n$

6.8 Direito de personalidade do inventor

Erro! Indicador $n$

6.9 Objeções contra o direito do inventor

Erro! Indicador $n$

6.10 A possibilidade de colaboração

Erro! Indicador $n$

6.11 Dos requisitos

Erro! Indicador $n$

6.12 Caráter da invenção.

Erro! Indicador $n$

6.13 Das Invenções não passíveis de patenteamento

Erro! Indicador $n$

6.14 Da garantia de prioridade

Erro! Indicador $n$

6.15 Os pedidos de patentes

Erro! Indicador $n$

6.16 Procedimentos

Erro! Indicador $\mathbf{n}$

6.17 Expedição da patente e direito de nominação

Erro! Indicador $\mathbf{n}$

6.18 Da duração

Erro! Indicador $\mathbf{n}$

6.19 Das invenções ocorridas na vigência de contrato de trabalho

Erro! Indicador $\mathbf{n}$

6.19.1 Hipótese de desconhecimento do inventor

Erro! Indicador $\mathbf{n}$

6.20 Extinção, caducidade e nulidade

Erro! Indicador $\mathbf{n}$

7. Considerações finais sobre o primeiro Código da Propriedade Industrial brasileiro

Erro! Indicador n

8. Ocorrências posteriores à entrada em vigor do Código de 1945

Erro! Indicador $n$

9. Os Códigos subsequentes.

Erro! Indicador n 
10. O Código da Propriedade Industrial de 1971

Erro! Indicador $n$

10.1 A teoria do monopólio

Erro! Indicador $n$

10.2 Requisitos para a patente: a introdução do "estado da técnica"

Erro! Indicador $n$

10.3 Garantia de Prioridade

Erro! Indicador $n$

10.4 Invenções que não receberiam patente

Erro! Indicador $n$

10.5 Sobre os pedidos de patentes de invenção

Erro! Indicador $\mathbf{n}$

10.6 Contrato de trabalho e invenções

Erro! Indicador $\mathbf{n}$

10.7 A expedição da patente

Erro! Indicador $\mathbf{n}$

10.8 Da exploração da invenção por terceiro não autorizado

Erro! Indicador $n$

10.9 O prazo de duração da patente

Erro! Indicador $n$

11. Alternativa ao sistema de patentes

Erro! Indicador $n$

11.1 A questão do tempo de duração da patente

Erro! Indicador $n$

11.2 Certificado de autoria de invenção.

Erro! Indicador $n$

\section{PARTE II}

\section{CONSIDERAÇÕES SOBRE O DIREITO MODERNO BRASILEIRO}

Capítulo V - Considerações sobre o direito moderno brasileiro

Erro! Indicador $n$

1. O acordo TRIPs e a nova legislação brasileira Erro! Indicador $n$

2. As principais alterações promovidas pela lei

Erro! Indicador $n$

2.1 O princípio da exaustão e outras mudanças

Erro! Indicador $n$

3. A doutrina posterior à nova lei e outras considerações

Erro! Indicador $\mathbf{n}$

4. O direito do usuário anterior

Erro! Indicador $n$

\section{PARTE III \\ REFLEXões FinAis E CONTRIBUiÇÃO AO ESTADO dA ARTE CONCLUSÕES}

Capítulo VI - Reflexões finais e contribuição ao estado da arte

Erro! Indicador $n$

1. Reflexões estruturais Erro! Indicador $n$

2. Diferença entre o direito de "autor" e o de inventor

Erro! Indicador $n$

3. Conteúdo do estudo Erro! Indicador $n$

4. Sugestões de melhoria

Erro! Indicador $\mathbf{n}$

5. Noções finais de natureza, fundamento e as bases de uma teoria para

o estudo do direito do inventor.

Erro! Indicador $n$ 


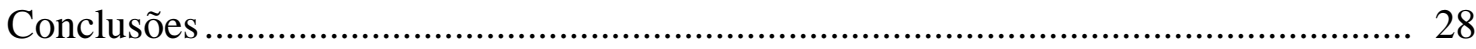

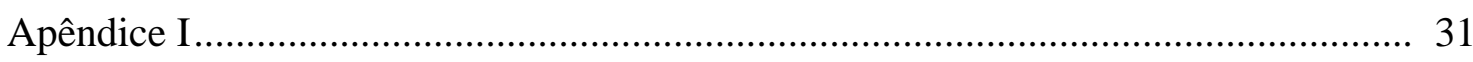

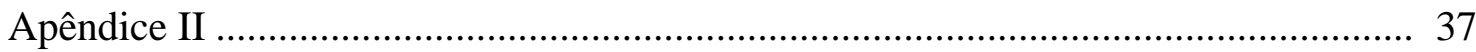

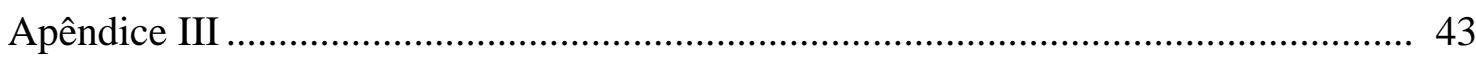

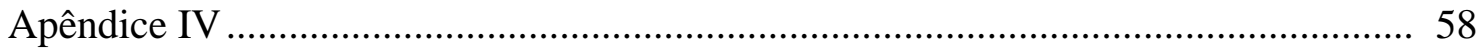

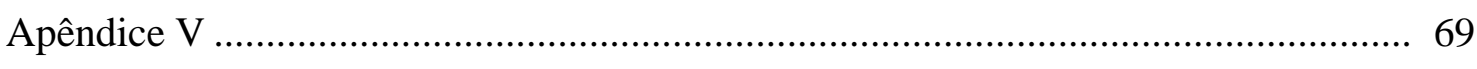

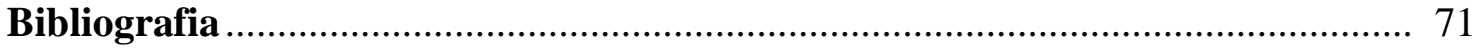

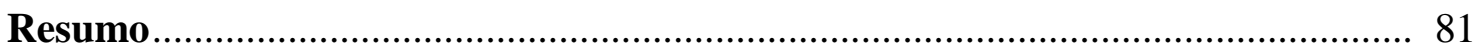

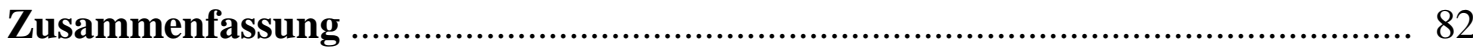

Riassunto 


\section{INTRODUÇÃO $^{1}$}

\section{A inventividade no Brasil e o direito do inventor}

A transmissão de vozes por rádio. Protótipos do que posteriormente se tornou a máquina de escrever. Sistemas de telecomunicação inovadores e, em tempos mais recentes, o identificador de chamadas telefônicas. O aeróstato. Por fim, o avião. A criatividade brasileira, de que são testemunho os inventos ora citados (os quais, pelo simples fim ilustrativo com que foram mencionados, não se apresentam em ordem cronológica), desponta inegável, nada obstante a dispersão que por vezes a caracteriza. Isso não impediu, porém, que impressionantes objetos fossem criados, bem como, no tocante às fontes legais, que uma complexa história se desenrolasse.

Nesse sentido, mostra-se também surpreendente o fato de o Brasil ter sido, de acordo com a doutrina, ${ }^{2}$ o quarto país ${ }^{3}$ no mundo a ter uma legislação específica para, supostamente, garantir proteção aos inventores e seus produtos - o Alvará do Príncipe Regente, de 28 de abril de 1809. A surpresa se justifica por não haver, naquele período da

(1) Acerca das opções metodológicas que serão empregadas ao longo deste trabalho, como formas de citação e referências de bibliografia, v. as "Notas Sobre a Metodologia Adotada", na sequência a esta Introdução, à p. 28.

(2) V., por todos, J. GAMA CERQUEIRA, Tratado da Propriedade Industrial, Vol. I, 3. ed., Rio de Janeiro, Lumen Iuris, 2010, p. 4, nota 5. Ao se referir à quarta colocação do país na ordem cronológica das normas de proteção ao direito do inventor, J. GAMA CERQUEIRA relaciona o Statute of Monopolies inglês, de 1623, como sendo a primeira, e as leis dos Estados Unidos, de 1790, e a Francesa, de 7 de janeiro de 1791, como sendo respectivamente a segunda e a terceira. Essa posição confronta o que escreveu G. VANDER HAEGHEN (Brevets D'Invention, Marques et Modèles, Bruxelles, Ferdinand Larcier, 1928, p. 475), que consignou como primeira lei brasileira, sobre o tema, a promulgada em 1830, após a proclamação da independência, sendo notório o desconhecimento da existência do Alvará de 1809.

Não obstante o ora demonstrado, a doutrina tem discordâncias de relevo a respeito do tema. Nesse sentido, C. Costa Rodrigues (A Inventiva Brasileira, Vol. II, Brasília, Instituto Nacional do Livro, 1973, p. 538) insere o Brasil não em quarto, mas em quinto lugar entre os países que editaram norma semelhante, inserindo, como a primeira delas, a da República de Veneza, de 1474, à qual se seguiriam as já mencionadas. Já N. PIRES de CARVAlHo (As Origens do Sistema Brasileiro de Patentes - O Alvará de 28 de abril de 1809 na Confluência de Políticas Públicas Divergentes - Parte I, in RABPI 91, p. 24) é mais veemente ao contestar o ensinamento de J. GAMA CERQUEIRA, pois, segundo aquele Autor, diversos Estados da América do Norte, antes de sua independência, já teriam adotado leis de "patentes". Além disso, cita a colônia grega Síbaris como sendo introdutora de regime de exclusividade a criações culinárias, a própria lei de Veneza e o fato de que, no Séc. XVI, a concessão de privilégios de invenção e para a introdução de novas máquinas já era prática corrente em Portugal, Sicília, Espanha, França e em outros locais diversos. Sobre a questão histórica, mais será exposto no Cap. I, Item "2", inclusive a respeito das normas antigas ora mencionadas.

(3) Embora, naquele momento, ainda se tratasse de colônia de Portugal. Cf., para mais detalhes, o Cap. I, adiante. 
história, desenvolvimento industrial na então colônia ${ }^{4}$ comparável ao de outras nações que já haviam adotado regras de proteção aos objetos resultantes de invenções, o que poderia levar à impressão de que o pioneirismo não estaria restrito às mentes inventivas.

A ideia criadora, que para alguns se mostra como o simples estágio teórico da invenção, ${ }^{5}$ demanda esforço para a concreta realização. Esse empenho construiu em terras brasileiras, ao longo dos séculos, um patrimônio imaterial deveras sugestivo, embora não opulento. É possível ainda alegar que o binômio necessidade-oportunidade, designado como uma das forças motrizes da criação humana, deita, no Brasil, raízes que remontam ao período que antecede o descobrimento. À guisa de exemplo, veja-se que a produção de fogo, por índios da região sul, fazia-se a partir de engenhoso aparelho, formado por uma espécie de prancha, a ser apoiada sobre o ombro, com um suporte específico e uma haste flexível. Introduzindo esta em um orifício, comprimiam-na contra o ombro e, com movimentos circulares, rapidamente criavam chamas. ${ }^{6} \mathrm{O}$ brasileiro, em várias áreas do conhecimento, é em regra criativo.

Quando, destarte, são contrapostas todas as afirmações acima, pode-se chegar à impressão inicial de que o direito do inventor aqui se desenvolveu, desde muito cedo, para acompanhar a criatividade brasileira.

Além disso, há diversos outros arquétipos aptos a ilustrar a atividade criadora nacional. Continuar a relatá-los, contudo, retiraria as presentes linhas do rumo que se pretende a elas conferir, pois não é o escopo desse trabalho tratar diretamente da

(4) Abandonando a acepção moderna do vocábulo "indústria", no sentido de "produções em série", e adotando-o como sinônimo de elaboração de matéria-prima e inserção de produto acabado para consumo em mercado, o açúcar é o primeiro objeto de ramo industrial no Brasil. Dele se originam os senhores de engenho, primeira aristocracia rural. O açúcar e sua produção constituíram o "núcleo fundamental" da economia brasileira (cf. H.F. LIMA, História Político-Econômica e Industrial do Brasil, São Paulo, Companhia Editora Nacional, 1970, p. 25). Também se destacavam, no período colonial, as operações siderúrgicas, a que comumente se atribui importância menor do que a devida em realidade (op.cit., p. 37. V., ainda, a respeito, F.A. VARNHAGEN, História Geral do Brasil antes de sua Separação e Independência de Portugal, 10. ed., Belo Horizonte, Itatiaia-EDUSP, 1981, e a Dissertação de Mestrado no Programa de Pós-Graduação em História Social da USP do Prof. E. ToMACEVICIUS FILHO, Entre a Memória Coletiva e a História de "Cola e Tesoura": as Intrigas e os Malogros nos Relatos sobre a Fábrica de Ferro de São João de Ipanema, 2012). Outras atividades, como a exploração de tecidos (os indígenas já conheciam e usavam o algodão antes da descoberta) e a construção naval são também dignas de nota, mas não é em virtude delas que o Brasil passará a tratar, na esfera normativa, de direito do inventor. Além disso, o termo "indústria" se empregava já em sentido diverso do ora exposto quando se relaciona às nações que tiveram normas de patentes anteriores, consoante a menção da nota " 2 " a esta Introdução.

(5) Cf. C. Costa Rodrigues, A Inventiva Brasileira... cit. (nota “2”, supra), Vol. I, p. 29.

(6) Conforme lembra C. Costa Rodrigues (A Inventiva Brasileira... cit. <nota "2", supra>, Vol. I, p. 95). 
inventividade brasileira - ainda que ela seja um importante pano de fundo. O que se projeta fazer é, na verdade, analisar o fundamento do direito do inventor na história jurídica brasileira. Se a criatividade nacional é inegável, lícito seria imaginar que o direito pátrio faz justiça àquela qualidade, não só por ser necessário resguardar os criadores que geram desenvolvimento tecnológico ao país, mas também por neste último se ter iniciado muito cedo o tratamento normativo da matéria.

Não é, porém, o caso. Preso a conceitos estrangeiros - muitos deles adotados sem o necessário rigor jurídico-científico - e a limitações administrativas, o direito do inventor afastou-se cada vez mais do direito privado comum e se tornou uma pequena e quase imperceptível sombra do sistema em que hoje está inserido: a propriedade industrial. Esta, por sua vez, na parte em que toca às invenções, vê-se presa a uma burocracia que não respeita sequer as próprias regras ${ }^{7}$ e que se mostra mais ligada a questões procedimentais do que ao cerne do direito.

Logo, o que se pretende fazer é o estudo de como se desenvolveu, na história do país, o direito positivo e a doutrina relativos ao inventor. A abordagem histórica mostrou-se como a melhor maneira de executar a proposta de trabalho e, com isso, comprovar o que ora se disse. Isso implica, necessariamente, analisar os monumentos legislativos, que servirão de referência cronológica.

Delimitam-se, assim, o escopo espacial e o limite temporal do conteúdo do trabalho: a história do direito no Brasil, quanto ao primeiro, e, no que diz respeito ao segundo, a evolução das diferentes normas que trataram dos direitos do inventor, razão do uso da expressão "perspectiva histórica". Sendo o período estudado bastante extenso (iniciando-se no período colonial e se encerrando com o último dos "Códigos" da Propriedade Industrial, do ano de 1971, além de contar com reflexões sobre o direito moderno), mostrou-se necessário esse recorte verticalizado.

(7) A censura não provém exclusivamente do autor deste trabalho. N. SILVEIRA, nos comentários de atualização que faz à obra de J. GAMA CERQUEIRA (Tratado... cit. <nota "2", supra>, Vol. I, p. 21), lembra que, desde sua criação em 1970, o Instituto Nacional da Propriedade Industrial - INPI, autarquia federal com sede legalmente estabelecida no Distrito Federal (art. 1. ${ }^{\circ}$ da Lei 5.648, de 11 de dezembro de 1970), continua localizado no Rio de Janeiro. 
Já a expressão "fundamento do direito" do inventor, aqui, é empregada em seu sentido de etiologia jurídica, ${ }^{8}$ ou seja, daquilo que dá causa, origem, ao próprio direito. E o que origina o direito do inventor é o ato-fato da invenção.

Do citado ato-fato da invenção se irradia um feixe de direitos, os quais podem ser assim descritos: 1. o direito autoral de personalidade; 2. o direito de nominação, posterior ao de personalidade, conquanto o último se exerça assinando-se o trabalho ou não e 3 . o direito de uso e exploração, ${ }^{9}$ vertente patrimonial do ato de criar uma solução técnica. $\mathrm{O}$ direito positivo pátrio relegou pouco espaço aos dois primeiros, todavia, ao menos quando o seu sujeito é um inventor. Quanto ao terceiro deles, o aspecto patrimonial das criações tecnológicas manteve estreita conexão com a gama de requisitos necessários à concessão de "patentes", formulação histórica que visa à regulação do mercado de conhecimento técnico, regulação esta que se relaciona a muitos temas diferentes, dentre os quais é possível enumerar a natureza da invenção ou do direito sobre ela. A criação é o centro dessa temática.

\section{A criação}

Como ressalta N. SiLVEIRA, antes de planejar corretamente a economia e de poder produzir em série o quanto necessário para satisfazer suas necessidades, o homem já exercia diálogo intenso com a natureza, transformando-a e aproveitando-a em seu benefício. Trata-se de criações oriundas da "técnica". ${ }^{10}$

A par das aptidões técnicas, o homem ainda desenvolveu o que se costuma chamar de "sentimento estético". A arte nada mais seria do que o resultado natural do organismo humano, capaz que é de experimentar singulares sensações a partir da combinação de diversos elementos.

Esse sentimento estético remonta aos primórdios da civilização e as criações dele provenientes são hoje protegidas pelo direito, assim como se protegem as criações oriundas

\footnotetext{
(8) Cf. E. PICARD, O Direito Puro, 2. ed., Bahia, Progresso, 1954, p. 305-306.

(9) Cf. F.C. PONTES DE MIRANDA, Tratado de Direito Privado - Parte Especial, t. XVI, Direito das Coisas: Propriedade Mobiliária (Bens Incorpóreos) - Propriedade Intelectual - Propriedade Industrial, 2. ed., Rio de Janeiro, Borsoi, 1956, p. 250.

(10) A Propriedade Intelectual e a Nova Lei de Propriedade Industrial (Lei 9.279, de 14.05.1996), São Paulo, Saraiva, 1996, p. 1.
} 
da "técnica". A criatividade do homem pode se exercer então, segundo aquele Autor, ${ }^{11}$ no campo da estética ou no da técnica. Daí a divisão da tutela jurídica a essa criatividade em dois ramos: ${ }^{12}$ o direito a que se convencionou denominar "de autor", que teria por objeto a criação do primeiro campo, e a propriedade industrial, que, entre outras funções, garantiria proteção jurídica, em princípio, a invenções técnicas. Costuma-se aglomerar os dois mencionados ramos em uma grande classe geral: a propriedade intelectual.

A mera atividade original do criador é suficiente para que se lhe conceda a proteção no caso de criação estética. Tal, porém, não se verifica no direito moderno (como de certa maneira não ocorria no antigo, pela submissão ao mecanismo das patentes) quando se trata das acima descritas criações "técnicas". Para que se lhe reconheça a titularidade, faz-se preciso verificar a existência de alguns requisitos, necessários à obtenção de uma patente de invenção.

Mas aí entra o dever crítico norteador deste trabalho, voltado a questionar essa "lógica" e a tentar decifrar se há justificativas jurídicas para ela. Quais os motivos para que haja essa restrição ao alcance do direito do inventor a explorar sua criação? Qual o sentido e fim dessa sistemática?

Afinal, o Brasil dispôs um sistema voltado à proteção do direito do inventor? Garantiu o ordenamento campo propício à contribuição e ao desenvolvimento técnico, ou a preocupação maior foi com os investimentos externos e o auxílio à importação de técnicas estrangeiras?

Assim, outra proposição que se faz, partindo da análise das fontes informadoras, do estudo do momento histórico da composição de tais fontes, e, ainda, da doutrina mais relevante, é verificar se o direito brasileiro possui, ou não, verdadeiro sistema de proteção ao direito do inventor, em resposta às perguntas ora elaboradas.

Afirmou-se, também, logo no início desta Introdução, que o ato-fato criador da invenção é o elemento que gera o direito do inventor. Poderia, então, ficar a dúvida sobre o que efetivamente se pretende fazer, pois, se o direito se inicia com o ato da criação, prescindível o exame das fontes em princípio.

(11) Cf. N. SILVEIRA, A Propriedade Intelectual e a Nova Lei... cit. (nota “10”, supra), p. 2.

(12) Configura-se discutível a divisão, como será visto de maneira mais detalhada no Cap. III do presente trabalho. Ela é todavia adotada, neste ponto, apenas para fins descritivos. 
Mas o ato de acompanhar as fontes, em perspectiva histórica, prestar-se-á exatamente à tentativa de comprovar a hipótese ora lançada, pois, se o direito positivo lançou restrições ao ato-fato da criação, inválida tornar-se-ia a proposição.

Essa, então é a hipótese de trabalho relativa à perspectiva histórica. A partir dela, pretende-se ter subsídios suficientes à comprovação da teoria original de trabalho já citada, o que permitirá, inclusive, verificar se a sistemática brasileira que envolve o direito do inventor é satisfatória.

Buscar-se-á verificar, ademais, se a técnica legislativa ao longo de mais de dois séculos teve algum denominador comum, um liame lógico, além de extrair a natureza que, ao longo do direito brasileiro, conferiu-se à matéria objeto deste trabalho.

Um alerta é necessário, porém: escolher a via de exame de praticamente toda a extensa legislação nacional ao longo de intervalo tão dilatado faz imperioso que se escolham rigorosamente os tópicos a serem analisados. O estudo de um momento amplo obriga o pesquisador a considerar o todo e os problemas de maneira relativa, ${ }^{13}$ especificamente pela profundidade com que se deram as mudanças objetivas sofridas pelo Brasil. Fácil seria perder-se em meio à miríade de informações disponíveis caso não houvesse critério rígido.

Três, pois, serão as abordagens que se pretende adotar a respeito da criação tecnológica inventiva e sua relação com o direito posto:

1. A verificação dos motivos que levaram à elaboração das normas;

2. A análise crítica das fontes informadoras;

3. Quando cabível, o diálogo com a doutrina.

(13) Cf. E. CARone, O Pensamento Industrial no Brasil - 1880-1945, Rio de Janeiro, Difel, 1977, p. 5. Este Autor entende (op.cit., p. 6) que o Brasil teve uma entidade ligada à indústria, a SAIN - Sociedade Auxiliadora da Indústria Nacional, de 1831 (sobre a qual mais se falará no Cap. III), antes de aqui existir uma indústria propriamente dita, na acepção moderna da palavra, acepção esta que, aliás, somente passaria a constar do estatuto daquela sociedade em 1867. Quando a última se transforma em Centro Industrial do Brasil (1904), à liderança de Antonio Felício dos Santos somam-se nomes como o de Jorge Street, Vasco Cunha, Serzedelo Corrêa e outros, que constituiriam a "primeira geração de industrialistas" brasileiros. A segunda viria a surgir em 1920, tendo como expoentes Roberto C. Simonsen, Euvaldo Lodi, João Daudt d'Oliveira e outros. Até esse momento a indústria local se incorporava às associações comerciais. Utilizam-se essas informações da doutrina com o mesmo fim daquelas constantes do Item "1" desta Introdução: para demonstrar que às normas brasileiras da época, especialmente as de 1809 (objeto do Cap. I) e de 1830 (material de base do Cap. II), não necessariamente correspondia o avanço industrial. 
Ao fim, pretende-se oferecer sugestões de lege ferenda e contribuições ao estado atual da arte.

Não se tratando de estudo casuístico, a referência a enunciados de jurisprudência e a julgados somente será empregada quando houver necessidade de ilustrar algum aspecto relevante do texto.

Ainda, no tocante ao diálogo com a doutrina, não se mostrará possível abordar tudo quanto escrito a respeito de invenções técnicas. O que se mostra necessário é, pois, verificar o que de mais relevante houve em termos de contribuição doutrinária que guarde relação com o fundamento do direito do inventor.

\section{O precoce envolvimento brasileiro com normas de proteção ao direito do inventor}

O ano: 1809. Tem-se então o início surpreendentemente precoce da legislação brasileira acerca de invenções e produtos técnicos. Ainda que esse começo não se tenha feito acompanhar da necessária industrialização - pois parece ser característico, das normas brasileiras de então e de hoje, serem deveras mais avançadas do que a realidade social e econômica nas quais se inserem -, deve-se a ele uma história de desenvolvimento legislativo repleta de detalhes que, geralmente, passam ao largo do conhecimento geral.

J. GAMA CERQUEIRA afirma que vigorava, então, no país, o que compreende como o mais "odioso" regime colonial que poderia haver e que não o tornava, de maneira alguma, propício ao desenvolvimento, especialmente na seara industrial. Via-se em terras brasileiras grande potencial de exploração das riquezas naturais, e a política da coroa parecia, com algumas exceções, direcionar-se exclusivamente em tal sentido, criando, inclusive, entraves às atividades que pudessem trazer riscos a sua soberania ou promover ideais de liberdade econômica na colônia. ${ }^{14}$

Chegada a família real ao Brasil, porém, não será longa a espera para que se publique o Alvará de 28 de abril ${ }^{15}$ do citado ano de 1809 , alterando o quadro até então reinante no que dizia respeito às invenções e estabelecendo algumas das bases da disciplina do direito

(14) Tratado... cit. (nota “2”, supra), Vol. I, p. 49. Essas alegações de GAMA CERQUEIRA - que, sabe-se hoje, são contestáveis, de acordo com o conteúdo das informações fornecidas na nota “4” desta Introdução, entre outros fatores - foram utilizadas apenas como meio de ilustrar o contraste da aparente rapidez da tomada de decisões quando do estabelecimento da coroa no Brasil, no que interessa ao direito do inventor.

(15) Demonstrar-se-á, no Cap. I, que a data do documento também é objeto de debate. 
do inventor.

O estudo do Alvará de 1809 será o objeto específico do Capítulo I, em que se pretende demonstrar as razões para sua criação e o porquê de o Brasil se antecipar a tantos outros países no ato de tentar regulamentar a matéria.

A precocidade, porém, em relação ao que ocorria no restante do mundo não é exclusiva desse Alvará. Em 14 de outubro de 1882, editou-se a Lei 3.229, pela qual se conferia o "privilégio" da invenção (apesar do conteúdo do $\S 1 .^{\circ}$ de seu art. $2 .^{\circ}$, que falava em "prioridade do direito de propriedade do inventor") para novos produtos industriais, para novos meios ou para a nova aplicação de métodos conhecidos para a obtenção de produto ou resultado industrial, além, por fim, da concessão destinada ao melhoramento de invenção já abrangida por "privilégio", fosse pelo próprio inventor, fosse por terceiro. ${ }^{16}$ Mas o art. $2 .^{\circ}$ desse diploma legal previa a possibilidade de inventores, privilegiados em outras nações, obterem a confirmação de seus direitos no Brasil, espécie de proteção que somente seria alcançada no restante do mundo um ano depois, com o advento da Convenção da União de Paris. ${ }^{17}$

À medida que a legislação se alterou - às vezes trazendo novidades relevantes como as mencionadas no parágrafo anterior, outras criando restrições indesejadas -, também mudaram os requisitos para que alguém pudesse, perante o sistema imposto pelo ordenamento, proclamar-se inventor de algo que, nos dias atuais, deve ter novidade, atividade inventiva e ser passível de aplicação industrial.

\section{Os requisitos atuais para a obtenção de patentes: novidade, atividade inventiva e aplicação industrial}

\subsection{A novidade}

A novidade, objetivamente considerada, é a essência do requisito da tutela a criações técnicas. ${ }^{18}$ Trata-se de invento nunca exposto ao público, e tal requisito pode ser visto tanto pelo ângulo cognoscitivo, de não conhecimento generalizado anterior dentro de parâmetros

(16) Cf. J.C. TInoco SoARes, Tratado da Propriedade Industrial - Patentes e seus Sucedâneos, São Paulo, Jurídica Brasileira, 1998, p. 40 e seguintes.

(17) A Convenção, especificamente quanto aos debates que a antecedem, será objeto de estudo do Cap. III.

(18) Cf. D.B. BARbosA, Uma Introdução à Propriedade Intelectual, 2. ed., Rio de Janeiro, Lumen Juris, 2003, p. 365. 
estabelecidos, quanto pelo aspecto econômico, ou seja, conquanto a criação não tenha ainda sido posta em prática, o que corresponde a sua não inserção em meio industrial. A novidade também pode ser entendida sob o ponto de vista meramente territorial, o que pode gerar sua classificação como absoluta, entendendo-se que a tecnologia não se fez conhecer em lugar algum, ou relativa, direcionada apenas a determinado espaço geográfico. Diferencia-se a novidade da "originalidade", relativa a obras literárias ou artísticas em geral, porquanto a última pode ser considerada relativamente ao âmbito pessoal do autor e, portanto, em caráter subjetivo. A criação nova em sentido objetivo tem, concretamente, a característica de "desconhecida" como situação de fato. A novidade subjetiva corresponde a um novo conhecimento em relação ao arcabouço de sabedoria do sujeito, em particular, enquanto a novidade objetiva é algo que ainda não existia para o restante da coletividade, ou não era dela conhecido. ${ }^{19}$

\subsection{A atividade inventiva}

Esse requisito, que também pode ser considerado, grosso modo, como a "não obviedade" da invenção tendo em vista criações já conhecidas anteriormente, mostra-se essencial na apreciação do deferimento, ou não, da patente de invenção.

Diferencia-se este requisito do "ato inventivo", 20 o qual, por se aplicar apenas aos “modelos de utilidade", não será examinado no presente trabalho.

Além disso, não se mostra de todo possível explicar, a contento, o alcance desse requisito sem tratar, por exemplo, do "estado da técnica", o que, por ser de difícil e complexa abordagem, será detidamente examinado no Capítulo IV deste trabalho.

\subsection{A aplicação industrial}

A solução a que o invento deve atender, conforme se infere de praticamente todas as legislações nacionais, deve ser um problema técnico, atinente a alterações dos estados da natureza, direcionado às várias formas de indústria. Segundo J. KOHLER, ${ }^{21}$ ela caracteriza a própria invenção.

\footnotetext{
(19) Cf. N. SILVEIRA, Propriedade Intelectual: Propriedade Industrial, Direito de Autor, Software, Cultivares, 4. ed., Barueri, Manole, 2011, p. 9.

(20) V. os arts. 9. ${ }^{\circ}$ e 14 da Lei 9.279, de 14 de maio de 1996.

(21) Manuale delle Privative Industriali, Milano, Società Editrice, 1914, p. 47, § 13.
} 
Essa solução pode, eventualmente, não trazer ganho prático ou comercial sobre algo que já existe. Afigura-se possível que a melhoria sobre o "estado da técnica" 22 seja apreciada no avaliar da atividade inventiva, mas o que se busca, aqui, é a aplicabilidade prática da criação. ${ }^{23}$

Possuindo os três requisitos acima descritos, a invenção poderá vir a receber proteção de acordo com o sistema de exclusividades estabelecido na propriedade industrial. As normas, porém, nem sempre trouxeram todas essas exigências. Por isso, mostra-se necessário examinar, ao longo do desenvolvimento do Direito brasileiro, quais eram os requisitos legais para que, ao inventor, fosse conferida uma patente, o que se enquadra na análise histórica.

\subsection{O fenômeno da sociedade do conhecimento}

O último dos requisitos sobre que se falou brevemente no Item anterior depende mais das questões econômicas e de industrialização do que do direito em si. Mas a economia moderna baseia-se no conhecimento, ${ }^{24}$ não mais apenas nos meios produtivos. Os desafios da apropriação dos resultados do trabalho de criações humanas de cunho tecnológico são temas que o direito, ao menos no Brasil, não tem enfrentado com a devida força. A afirmação, que pode parecer austera e contrária à constatação de as normas terem aqui se iniciado muito cedo, toma por base reflexões do autor deste trabalho decorrentes de vários anos como revisor editorial sênior de uma das maiores editoras jurídicas brasileiras e, posteriormente, como procurador da maior instituição da América Latina em sua linha de atuação, o centenário "Instituto de Pesquisas Tecnológicas do Estado de São Paulo S.A. IPT”. Fala-se em extensão dos limites da propriedade intelectual, mas, ao menos quanto a invenções, não é o que se verifica. Muitos dos desafios se explicam pela enorme dificuldade (diria quase impossibilidade) que o jurista encontrará se pretender investigar o direito do inventor dissociado do "sistema de patentes". Por isso, como estudo histórico, passa este trabalho necessariamente pela abordagem das patentes de invenção, pois o lugar comum do tratamento do direito do inventor é ligar este àquelas.

(22) V., como dito, a respeito do "estado da técnica", o conteúdo do Capítulo IV do presente trabalho.

(23) Nesse sentido, D.B. BARBosA, Uma Introdução à Propriedade Intelectual... cit. (nota “18”, supra), p. 381-382.

(24) Nesse sentido, cf. L.M. Malavota, A Construção do Sistema de Patentes no Brasil: um Olhar Histórico, Rio de Janeiro, Lumen Juris, 2011, p. XI. 


\section{A patente}

Invenções há que não se amoldam a requisitos de "patenteabilidade". Tais inventos são criações como quaisquer outras, mas não merecerão o resguardo do que hoje se costuma relacionar ao chamado "direito industrial".

A patente, deferida pela administração pública após procedimento formal, mostra-se, na visão de J. GAma CERQueIRA, como sendo o ato expresso de reconhecimento, pelo Estado, do Direito do Inventor, que lhe assegura, em princípio, a propriedade ${ }^{25}$ e o uso exclusivo de seu invento pelo prazo legal. Como título conferido ao criador, seria ao mesmo tempo a comprovação de seu direito e a "chancela" estatal para seu exercício. ${ }^{26}$ Corresponde, na visão desse Autor, às expressões "carta-patente" ou "letras-patentes", 27 excluídas há muito do uso comum. ${ }^{28}$ Não se pode deixar de notar, também, a intenção que cerca a mantença de tal termo ainda nos dias de hoje, pois "patente" é algo visível, de fácil conferência, sendo que o sistema de proteção às invenções tem, como um de seus fins, que encerrado o prazo de exclusividade o invento caia em domínio público, tornando-se, portanto, "patente". O vocábulo viria a ser utilizado de modo expresso na lei inglesa de 1623 (que tratava, como se verá no Capítulo I, de Patents for 14 Years or less, for new Inventions).

Como suposta forma de proteção ao direito do inventor e, ao mesmo tempo, instrumento de regulação do que pode ou não ser entendido como criação intelectual industrialmente aplicável, as patentes são constantemente o cerne desse debate. Ocorre, porém que elas são uma parcela do direito patrimonial do inventor e com o último não se confundem. Este trabalho não possui a intenção de se focar apenas nelas, portanto. Com isso, projeta-se afastar o entendimento, incorreto, de que são elas o próprio direito do inventor. Não obstante, ao tratar deste, fatalmente se depara o pesquisador com a

(25) Diz-se "em princípio" porque muitas são as teorias, ao longo do desenvolvimento dos estudos acerca dos direitos sobre bens imateriais, que negam a qualidade de verdadeira "propriedade" à concepção inventiva. No Cap. III deste trabalho, serão debatidas diversas das correntes a respeito do tema. Já na Parte III, será analisada a natureza e o fundamento do Direito do Inventor de acordo com desígnios clássicos.

(26) Tratado... cit. (nota “2", supra), Vol. I, p. 140.

(27) V., também, D.S. Chisum et al., Principles of Patent Law: Cases and Materials, 3. ed., New York, Foundation Press, 2004, p. 3. Disserta-se nesse trabalho a respeito do caráter de "carta aberta" que se conferia ao instituto.

(28) Porquanto "patentes" ou "cartas-patentes" seriam provisões conferidas pelo governo para designar ofícios, privilégios, dignidade, etc. 
prevalência de estudos relativos aos diversos "sistemas" 29 de obtenção e proteção da patente. Existe uma quase ubiquidade das patentes, das quais não é possível se afastar, mas para as quais o trabalho também busca alternativas.

Direcionando-se as patentes a "invenções", e porque sobre essas recaem o interesse deste trabalho, não serão objeto de exame as meras descobertas.

\subsection{Diferença entre descoberta e invenção}

No conceito de A.B. BuYs DE BARROS, a invenção pressupõe atividade intelectual incidente, de modo direto, na realização de um objeto social que seja indicativo de progresso. Tratar-se-ia do expoente de um processo lógico dividido em etapas distintas, que compreendem:

a. Uma concepção abstrata do fim almejado;

b. A opção por um dos diversos caminhos que se apresentam com a ideia especulativa;

c. A determinação do meio idôneo para a obtenção do objetivo e

d. A consecução de tal meio.

Por sua vez, a descoberta não corresponde, diretamente, ao resultado da relação entre causa e efeito, o qual, embora possa tornar possível a descoberta, só o faz casualmente. Explica-se a descoberta com a percepção dos objetos, fenômenos e propriedade dos corpos que, posto existentes, não faziam parte do conhecimento humano. ${ }^{30}$

Por tal motivo, o presente trabalho também pretende demonstrar como se desenvolveram, historicamente, no Brasil, os requisitos das patentes de invenção, que além de serem usados para diferenciá-la da descoberta, geram exclusividade da exploração a seu titular.

(29) Inclusive, os títulos das obras doutrinárias partem dessa premissa. V., nesse sentido, os trabalhos de N. Pires de Carvalho (As Origens do Sistema Brasileiro de Patentes - O Alvará de 28 de abril de 1809 na Confluência de Políticas Públicas Divergentes, conforme as referências da nota "1" a esta Introdução, além de outras obras do mesmo Autor, a serem mencionadas na sequência do presente trabalho) e L.M. Malavota (A Construção do Sistema de Patentes no Brasil: um Olhar Histórico, com dados mencionados na nota "24", também nesta Introdução).

(30) Direito Industrial e Legislação do Trabalho, Vol. I, Rio de Janeiro, A. Coelho Branco, 1940, p. 142. 


\subsection{Da exclusividade, ou "direito de exclusiva"}

A maior parte das normas, no tratar da propriedade que garantem ao inventor, afirmam garantir igualmente o uso "exclusivo" da invenção. Trata-se de um tópico relevantíssimo de debate, especialmente quanto à compatibilidade desse uso "exclusivo" com a construção dos direitos reais no Brasil, o que será tema de análise no Capítulo IV.

Há, porém, uma ressalva de linguagem a fazer: parte significativa da doutrina brasileira é bastante influenciada pela de autores de língua inglesa, diversas vezes utilizados como parâmetros para a compreensão da estrutura do sistema de patentes e para fins de estudos jurisprudenciais. Isso ocorre, inclusive, em obras abalizadas, de que são exemplos recentes as de D.B. BARBosA ${ }^{31}$ e N. Pires de CARvalho. ${ }^{32}$ Segundo citada doutrina americana, a suposta relação de "troca" que se estabelece entre governo e inventor já foi comparada a um contrato, ${ }^{33}$ cujo conteúdo confere a seu titular um direito de excluir outros. Baseado, então, no termo inglês "exclusive", dá-se ao direito gerado pela patente o nome de "direito de exclusiva", havendo, ainda, os que preferem falar, unicamente, em "exclusivos". 34

Seguindo a tradição brasileira, porém, não se mostram justificáveis o termo e a expressão acima descritos, pois “exclusividade” já é um vocábulo bastante comum e o uso do estrangeirismo não se justifica por nada além da proximidade que se procura estabelecer com o sistema internacional de patentes. Por tal motivo, prefere-se a expressão "direito de exclusividade".

(31) Indicam-se nesse sentido as p. 97, 100, 101, 112 e 113 de Uma Introdução à Propriedade Intelectual... cit. (nota "18", supra) e a p. 1.101 de seu Tratado da Propriedade Intelectual, t. 2, Rio de Janeiro, Lumen Juris, 2013.

(32) A Estrutura do Sistema de Patentes e Marcas - Passado, Presente e Futuro, Rio de Janeiro, Lumen Juris, 2009, p. 110-112.

(33) De acordo com a jurisprudência americana (aqui empregada a título de explanação do argumento deste tópico e que não configura, alerte-se, material do qual se lançará mão com frequência ao longo deste trabalho), a patente é um contrato que se estabelece entre o inventor e o público, cujos termos o órgão oficial de patentes americano estabelece. Como forma de reconhecimento do benefício recebido, o inventor entrega ao público o conhecimento inovador e, em contrapartida, o público entrega a ele um "monopólio" que se expressa pelas reivindicações (DAVIS AIRFOILS, Inc. v. UNITED STATES, 124 F.Supp. $350,352<$ ct.cl.1954>).

No que tange, efetivamente, ao objeto de interesse e de estudo do presente trabalho, v., no Cap. III, Item "7.2.2", o que se disserta a respeito da teoria do contrato tácito.

(34) Com o faz, v.g., L.M. MalaVota, A Construção do Sistema de Patentes no Brasil... cit. (nota "24", supra), p. 1. 


\section{Da contribuição original}

Os estudos feitos no intuito de completar a tarefa proposta demonstraram que não há, na literatura jurídica brasileira, análise similar à que segue.

Mostra-se, ainda, necessário enfatizar que o único trabalho acadêmico que cuidou de fazer um esboço, breve e expedito porém, do desenvolvimento histórico da matéria no Brasil é o "Tratado da Propriedade Industrial", de J. GAMA CERQUEIRA, cujo primeiro volume, em que se encontram tais considerações, data de 1946. Ademais, a abordagem de GAma CERQueira é bastante genérica e voltada a institutos de toda a assim chamada "Propriedade Industrial", não isoladamente ao inventor. F.C. PONTES DE MIRANDA dedicou parcela ainda menor de espaço ao tema em sua obra. ${ }^{35}$ Outros trabalhos históricos cuidaram apenas do tema no séc. XIX, de modo específico, além de não terem por objetivo o direito em sua perspectiva etiológica.

Tampouco se logrou encontrar, na bibliografia especializada, trabalho no qual houvesse a proposição de conjugar o desenvolvimento do direito positivo com a análise do fundamento do direito do inventor. A comparação entre os diversos períodos históricos e a tarefa de verificar se, no decorrer das alterações legislativas, houve influência destas sobre o que se pode considerar como "fundamento" em si, são de inegável importância à ciência jurídica brasileira.

\section{Da divisão do trabalho em partes}

Três partes compõem a totalidade do trabalho que ora se apresenta: na primeira, pretende-se delinear detidamente o desenvolvimento histórico das fontes que, no geral, coincidem com as das patentes de invenção; na segunda, abordar-se-á brevemente o direito moderno e, na sequência, o cerne, o fundamento do direito do inventor, sem descurar de questões como sua natureza, ainda que se possa mostrar mais lógico tratar de questões principiológicas em âmbito introdutório, do que poderia resultar a dúvida sobre se não seria mais produtivo antecipar tais considerações para, posteriormente, abordar os direitos do inventor ao longo da história.

Mas esta estrutura é assim proposta porquanto o estudo dos fundamentos do direito do

(35) Tratado de Direito Privado - Parte Especial... cit. (nota “9”, supra), t. XVI, p. 211-216. 
inventor pode se valer, também, das colaborações histórico-legislativas, e a abordagem temporal de tais aspectos certamente contribuirá para uma conclusão mais próxima do que se deve entender como direito à criação técnica.

Portanto, na primeira Parte se tentará, tanto quanto possível, seguir a ordem cronológica das fontes informadoras, consoante já explicado. Na segunda Parte, serão tratados aspectos do direito brasileiro moderno, mas também com base nas normas editadas e, eventualmente, projetos legislativos.

Não obstante tudo o quanto já se esclareceu, faz-se imperioso relatar, desde o princípio, que se entende o direito do inventor como ramo do direito de autor, genericamente considerado. De maneira diferente, porém, do direito do criador de obra literária, cujo simples trabalho dotado de originalidade já o torna titular de criação juridicamente tutelada, o esforço do inventor não parece se limitar em si mesmo para receber proteção a seu direito. Como dito, um número de requisitos se mostra necessário a tanto. Questiona-se, a partir desse enfoque, se os requisitos da patente podem ser vislumbrados, também, como fundamento do direito do inventor.

Ademais, fala-se, muito, no caráter internacional dos direitos relacionados à propriedade industrial. Não obstante tal caráter, é inegável o interesse em analisar os caminhos seguidos no direito brasileiro, ao longo da história, para abarcar as invenções tecnicamente aplicáveis, muitas vezes com posições que antecipavam o que ocorria no restante do mundo. ${ }^{36} \mathrm{O}$ olhar, que não se desvia dos desígnios do direito estrangeiro, pois tal direito com ele se comunica ininterruptamente, cederá de certa forma espaço para verificar as escolhas das fontes e da doutrina brasileiras e suas eventuais consequências.

O estudo crítico das fontes também se prestará à tentativa de levantar elementos básicos de uma teoria do direito do inventor, algo que constará da Parte III. Por fim, a esta última Parte ainda se reservam as contribuições e sugestões que serão feitas à matéria.

(36) Isso se mostra especialmente verdadeiro quando são analisadas algumas das previsões da Lei 3.229, de 14 de outubro de 1882, e dispositivos previstos na Convenção da União de Paris relativos a privilégios já concedidos em outros países signatários (conforme já salientado no item "3" desta Introdução). Nesse sentido, v., adiante, o Cap. III. 


\section{CONCLUSõES}

O Brasil foi o quarto país no mundo a ter norma abstrata que versasse sobre direitos de invenção.

Sua primeira Constituição antecipou-se, em mais de meio século, ao princípio da propriedade do inventor sobre seus inventos, o qual somente seria aventado no Congresso Internacional de Propriedade Industrial, realizado em Paris no ano de 1878.

Além disso, inseriu em seu ordenamento regras de proteção a inventos estrangeiros antes da existência de uma convenção internacional. Nesse sentido, é possível alegar que ele esteve na CUP antes de ela existir.

Vê-se, então, que desde muito cedo temas do direito do inventor estiveram presentes na esfera jurídica do país.

Apesar disso, não se firmou, no Brasil, uma teoria efetiva do direito do inventor nem se realizou uma estrutura para proteger seus interesses, de modo específico. A busca da ratio legis e da estrutura de cada uma das normas analisadas neste trabalho leva a essa constatação.

A história das fontes, no Brasil, pode assim ser resumida:

1. influência de movimentos liberais, necessidade de promover algum grau de abertura econômica para atrair capitais e, também, de cumprir acordos anteriores (Alvará de 28 de abril de 1809);

2. influência também de movimentos liberais, anseio de romper drasticamente com o sistema anterior e importação de experiência jurídica estrangeira quase inaplicável aqui, consubstanciada no intuito de eliminar as corporações de ofício (Lei de 28 de agosto de 1830);

3. desejo de atrair investimentos estrangeiros, oferecendo proteção às técnicas de fora, além de respeitar princípios oriundos das discussões internacionais (Lei 3.129, de 14 de outubro de 1882);

4. integrar os temas da propriedade industrial, aumentar o tamanho do Estado no controle do sistema e consolidar o movimento de "departamentalização" do direito às patentes (Código da Propriedade Industrial de 1945); 
5. disseminar e auxiliar a transferência de tecnologia e aumentar ainda mais o controle estatal sobre as patentes (Códigos da Propriedade Industrial de 1967, 1969 e 1971);

6. adequar a legislação interna aos compromissos assumidos nas negociações que resultaram no acordo TRIPs (Lei 9.279/1996).

O auxílio efetivo ao trabalho de criação do inventor, como autor em si, não foi o pressuposto, a ratio da construção do ordenamento brasileiro. A importância do fundamento do direito do inventor, então, ficou relegada a plano quase ínfimo. Interessam mais os requisitos de patenteabilidade do que o ato de criação em si.

Inventor é o criador de solução técnica, materialmente aplicável. O bem juridicamente tutelado é o que apresenta solução prática até então desconhecida.

A tradição jurídica brasileira mostra-se inequivocamente inclinada à teoria de que o inventor é o proprietário de suas invenções.

Aliás, a dúvida a respeito de propriedade ou domínio sobre bens imateriais não mais se sustenta.

Porém, apesar da inegável substância de propriedade e da tradição jurídica que vem da Constituição de 1824, o tratamento que a ordem confere, especialmente após os anos 1970, ao inventor, no aspecto patrimonial, é de monopólio, ou, mais tecnicamente, de direito de "exclusividade", ressalvando-se apenas a exceção do usuário anterior, prevista na lei atualmente em vigor.

Funda-se o direito do inventor no ato-fato da invenção.

Fundamento, para os fins deste trabalho, é empregado em seu sentido de etiologia jurídica, ou seja, daquilo que lhe dá causa.

Do ato-fato da invenção se irradia um feixe de direitos, os quais podem ser assim descritos: 1. o direito autoral de personalidade; 2. o direito de nominação, posterior ao de personalidade, conquanto o último se exerça assinando-se o trabalho ou não e 3. o direito de uso e exploração, vertente patrimonial do ato de criar uma solução técnica.

O direito positivo pátrio relegou pouco espaço aos dois primeiros, todavia, ao menos quando o seu sujeito é um inventor. Inclusive, há autores que os entendem incompatíveis com a sistemática constitucional de 1988, o que, porém, não pode ser aceito.

Quanto ao terceiro deles, o aspecto patrimonial das criações tecnológicas manteve 
estreita conexão com a gama de requisitos necessários ao deferimento de "patentes", formulação histórica que visa à regulação do mercado de conhecimento técnico.

As diversas fontes estudadas limitam-se a tratar de invenções patenteáveis para conferir direitos de exploração ao inventor. Por tal motivo, o ramo histórico se ateve a vários tópicos relacionados a patentes de invenção e suas bases formadoras. Isso não se apresentou, porém, como empecilho à verificação da natureza e fundamento do direito do inventor.

O termo "privilégio" está ligado ao regime monárquico e é tecnicamente incorreto.

Ainda, não há eficácia concessiva de patente pelo Estado. Estando preenchidos os pressupostos, deve-se deferi-la e expedi-la. Não se trata, pois, de concessão, por razões similares às da inexistência de privilégios no ordenamento brasileiro.

Os requisitos da patente podem ser considerados fundamento do direito do inventor, mas apenas de maneira oblíqua. Sendo o direito à patente um dos direitos do inventor, e baseando-se a patente nos requisitos, essa é a relação que os últimos mantêm com aquele.

O direito do inventor é objeto da propriedade industrial unicamente no que tange à obtenção e exploração da patente.

Diminuir a distância da pesquisa científica à tecnológica é algo para o que o direito poderia contribuir, desenvolvendo mecanismos de incentivo para tanto.

O estudo lastreado na perspectiva histórica permitiu que se delineassem as bases de uma teoria para o estudo do direito do inventor. Também auxiliou ao oferecimento de sugestões de lege ferenda e de aperfeiçoamento do sistema.

Demonstrou-se, por fim, a partir da perspectiva histórica das fontes, que o elemento gerador de direito ao criador de invenções técnicas é o citado ato-fato da criação, que se configura como o verdadeiro fundamento do direito do inventor. 
Relatório (Parcial) do Conde de Villeneuve (Cap. III, Itens "6.5" e 6.5.1") e Aviso de 29 de janeiro de 1881 (Cap. III, Item "6.7")

\section{PROPRIBDADE INDUSTRIAL}

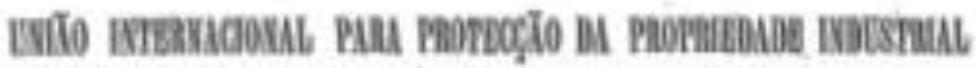

\section{RELATORIO}

Amaevas

\section{MANOEL BUABQUE DE MACEDO}

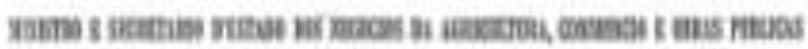




\title{
PROPRIEDADE INDUSTRIAL
}

\section{RELATORIO ACERCA DA CONFERENCIA INTERNACTONADL}

\author{
Munich, 30 de dezembro de 1880
}

Illm. e Exm. Sr.-Em desempenho da importante commissão que V. Ex. se dignou confiar-me em data de 14 de setembro deste anno, tenho a honra de apresentar a V. Ex. um relatorio synthetico ácerca da conferencia internacional, promovida em Paris pelo governo francez, afim- de propôr as bases de uma \& União • destinada a proteger em todos os paizes, por meio de uma legislação: uniforme, a propriedade industrial nas suas diversas manifestą̧̃es : privilegios de invenção, desenhos e modelos industriaes, marcas de fabrica e de commercio, e nome commercial. Desde o dia em que foram encetados os trabalhos da conferencia até o do seu encerramento, acompanhei passo a passo as discussões, dando conta a V. Ex. das mais notaveis occurrencias. Hoje, porém, cumprindo a promessa que fiz no meu officio de 23 de Novembro proximo passado, remetto a V. Ex., mais desenvolvidas e minuciosas, as informações que pude colher durante o debate.

0 estudo das origens da conferencia e um succinto esboço das diversas legislações relativas á propriedade industrial, pareeem-me indispensaveis para apreciar devidamente as discussões da mesma conferencia e os resultados que ella conseguiu, podendo-se então examinar com proveito qual o papel representado pelo delegado do Governo Imperial nesse congresso official, quaes as modificações que o projecto de convenção adoptado tende a introduzir em nossa legislação sobre a materia, e, emfim, quaes as ponderações que me foram inspiradas pelo embate das opiniões emittidas.

Permitta, pois, V. Ex. que passe a tratar dos seguintes pontos:

$1 .{ }^{\circ}$ Origem da conferencia internacional de 4 de novembro de 1880 ;

2. Legislação dos diversos Estados ácerca da propriedade industrial;

3. A conferencia internacional de 4 de novembro;

4. ${ }^{\circ}$ Modificações a introduzir na legislação brazileira como consequencias da adopção do projecto de tratado;

5. ${ }^{\circ}$ Considerações geraes sobre 0 assumpto da conferencia.

Propr. Industrial-V, II 2 


\section{ANNEXOS}

\section{Documento m}

Rosoluṣōos do Congresso Internacional das patontes do invonção, rounido om Vienna durante a Exposição Unirersal do 18ī3

1-A protecção das invenções deve ser garantida pelas leis de todas as nações cıvilisadas.

2-Para ser util e efficaz, uma lei sobre as patentes deve firmar-se nos principios seguintes:

(a)-Só o proprio inventor ou o seu representante legal deve poder obter uma patente.

(b) - Não se devé recusar patente aos estrangeiros.

(c) - Convém introduzir na realização destes principios um systema de exame prévio.

(d) - A patente deve conceder-se por quinze annos, ou com faculdade de a prolongar até quinze annos.

(e) - Ao conceder-se um privilegio, deve-se publical-o completamente para ser possivel a applica. ção technica da invenção.

(f) - As despezas para obter uma patente devem ser pouco avultadas; mas, no interesse do inventor, deve-se estabelecer uma escala progressiva de taxas permittindo-lhe abandonar, quando julgar conveniente, uma patente que não apresenta utilidade.

(g) - Por meio de uma organização normal da repartição das patentes, deve-se facilitar o conhecimento do conteúdo das patentès, afim de saber-se tambem quaes as patentes que ainda estĩo em vigor.

(h) - Convèm estabelecer regulamentos obrigando o privilegiado, nos casos em que o interesse publico assim o exigir, a permittir o emprego da sua invenção a todas as pessoas sérias que o requererem, mediante justa indemnização.

(i) - A não applicação de uma invenção n'um paiz não acarreta comsigo a caducidade da pațente, si esta já foi posta em pratica de algum modo e si foi possivel aos habitantes deste paiz comprarem e utilisarem tal invenção.

(k) - Para os demais pontos, e especialmente no que se refere ás formalidades de concessão das patentes, o Congresso conforma-se com as disposições das leis ingleza, norte-americana e belga, e como projecto de lei de patentes preparado para a Allemanha pela Sociedade dos Engenheiros Allemães.

3-Em consequencia das grandes anomalias que existem entre o actual regimen das patentes e as relaẹues commercies internacionaes que se modificaram, uma reforma tornou-se necessaria, do modo mais manifesto, e é urgente que os governos se reforcem por estabelecer quanto antes um ajuste internacional ácerca da protecção das patentes.

4- 0 Congresso confere poderes á commissão preparatoria para proseguir na tarefa emprehendida pelo primeiro congresso internacional, e para empregar toda a sua influencia em diffundir o mais possivel e em executar os principios que o Congresso sanccionou.

כั- A commissão fica tambem autorizada a occupor-se em promover uma troca de opiniões sobrc 0 assumpto, e a organizar, em épocas determinadas, assembléas e conferencias entre os partidarios de proteç̧ão para as patentes.

6-Para esse fim, a commissão preparatoria tica encarregada de proceder como commissão executiva permanente, podendo chamar a si outros membros e indicar a data da proxima reunião do Congresso, no caso em que julgar util uma nova reunião para realizar as vistas foṛmuladas nas resoluções acima mencionadas. 


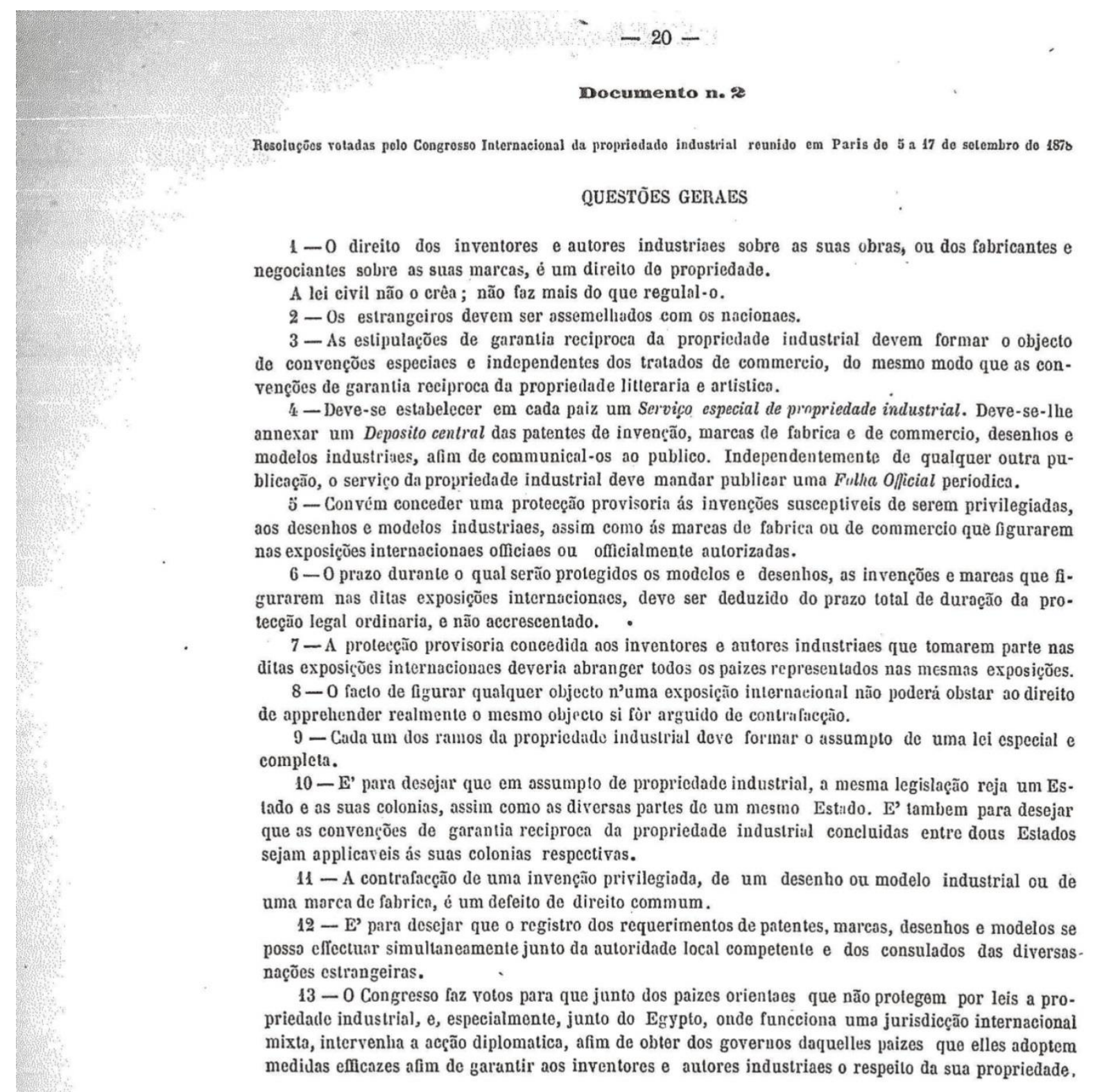

\section{PATENTES DE INVENÇAO}

1-Poderão ser privilegiadas todas as invenções industriaes, exceptuando as combinações e planos financeiros e de credito, $\theta$ as invenções contrarias á ordem publica e aos bons costumes. Devem-se conceder patentes aos inventores de productos chimicos, alimentarios e pharmaceuticos.

2 - Durante toda a sua duração, as patentes devem garantir aos inventores ou aos seus representantes legaes o direito exclusivo de empregar a invenção, e não um simples direito a um caso que lhes seria pago por terceiros que a empregarem. 
3-U principio de desapropriação por causa de utilidade publica é applicavel ás patentes de invenção. 0 caracter de utilidade publica deve ser reconhecido por lei.

4-A patente deve ser concedida a qualquer requerente por sua conta e risco. Comtudo, é util que o requerente receba um aviso prévio e secreto, especialmente no que se refere á novidade da in. venção, afim de que possu, á vontade, manter, modificar ou abandonar o requerimento.

5 -As patentes devem ser sujeitas a uma taxa. Deve ser esta periodica e annual.

6-A taxa deve ser progressiva, principiando por uma quantia moderada nos primeiros annos.

7- A taxa não poderá ser exigida senão no decurso do anno.

8 - Não deve ser prohibida por lei a importação, feita pelo dono do privilegio, para o paiz onde obteve o privilegio, de objectos fabricados no estrangeiro.

9-A caducidade da patente por falta de pagamento da taxa não deve poder ser pronunciada senão depois de expirar certo prazo, a contar da data do vencimento. Até mesmo depois de expirar esse prazo, deve-se admittir que o privilegiado justifique si causas legitimas impediram que pagasse.

10 - Convém admittir a caducidade por falta de emprego da patente. Tal caducidade deverá ser pronunciada pela jurisdicção eompetente.

11-0s direitos que resultam das patentes requeridas ou dos depositos effectuados nos differentes paizes para ụm mesmo objecto são independentes uns dos outros, e não solidarios de qualquer mođo que seja, como acontece hoje em dia em muitos paizes.

12- Roga-se aos Governos que empreguem a maior pressa possivel na concessĩo das patentes requeridas, e 0 Congresso faz votos para que o prazo decorrido entre o requerimento e a concessão não exceda de 3 ou 4 mezes.

\section{DESENHOS E MODELOS INDUSTRIAES}

1-Deve-se dar uma definição dos desenhos e modelos industriaes na lei que a elle se referir.

2-E' considerado como desenho industrial todo arranjo, toda disposição do traços ou côres destinados a uma produç̨ão industrial, e quaesquer cffeitos obtidos por combiną̧ões de tecedura ou impressão. - E' reputado modelo industrial toda obra em relevo destinada a constituir um objecto ou a fazer parte de um objecto industrial.

Não se acham comprehendidos nestas caterorias, embora sejam destinados a uma reproducęũo industrial, os desenhos que têm um caracter artistico, nem os objectos provenientes da arte do esculptor.

Quanto ás invençães em que a fórma só é procurada pelo autor por causa dos resultados industriaes obtidos, serão ellas regidas pela lei especial das patentes.

$3-$ A duração do direito de propriedade será de $2,3,4,5,10,15,20,30$ annos, á vontade do requerente. Si este direito fôr reclamado por uma duração inferior a 30 annos, poderá ser prolongado até o fim deste prazo, mediante o pagamento dos respectivos direitos.

A duração deve ser uniforme para todos os desenhos e modelos industriaes.

L - A protecção concedida pela lei aos autores de desenhos e modelos deve ficar subordinada á obrigação de um deposito prévio. - 0 deposito far-se-ha sob a fórma de uma amostra, specimen, bosquejo ou photographia. -0 deposito será conservado secreto durante 2 annos. -0 certificado de deposito deverá ser concedido por conta e risco do requerente.

5 -0 peso do maço lacrado nãu deve ser superior a 10 kilogrammas.

6- Ao expirar o prazo marcado para o deposito secreto, os desenhos e modelos industriaes devem ser postos á disposięão do publico, mas não devem ser publicados officialmente.-Todavia a folha official do serviço da propriedade industrial de cada paiz deve publicar periodicamente o nome dos requerentes e a indicação do objecto dos depositos.

7-E' para desejar que em todos os paizes a lei presereva que sejam cancellados dos competentes registros os ossentos reconhecidos fraudulosos pela autoridade ou jurisdição competente, assim como a substituição do nome do verdadeiro proprietario.

8 - 0 s registros de desenhos e modelos industriaes devem effectuar-se mediante o pagamento de uma taxa minima. 


\section{PROPRIEDADE INDUSTRIAL}

\section{AVISOS}

\section{Aviso de 29 de janeiro de 1881}

Approva o projecto de convençio e o protocollo de encerramento da Confereneia Internacional celebrada em Paris para protecção da propriedàde industrial

Illm. e Exm. Sr.-Tenho a honra de deslarar a V. Ex., em resposta ao seu Aviso de 8 do corrente, que este Ministerio approva o projecto de convenção e o protocollo de encerramento da conferencia internacional de Paris, reunida para o fim de assentar nos meios de dar protecção á propriedade industrial.

Deus guarde a V. Ex.-Manoel Buarque de Macedo - A S. Ex. o Sr. Pedro Luiz Pereira de Souza.

\section{Aviso de 26 de marẹo de 1881}

Louva o Ministro residente em disponibilidade, Julio Constancio le Villeneuve, pelo modo como se desempenhou da missâo de delegado do Governo Imperial na Conferencia Internacional para proteç̧âo da proprièuade industria

De posse do officio de 23 de novembro do anno proximo passado, em que V.S. me communicou haver a conferencia reunida em Paris a 4 daquelle mez, para estudar os meios de realizar uma União Internacional,- concluido os seus trabalhos, celebrando uma sessão solemne de encerramento para a assignatura da respectiva acta, que contém, sob a fórma 


\section{Quadro Comparativo das Leis do Período Imperial}

LEI DE 28 DE AGOSTO DE 1830

Art. 10 A Lei assegura ao descobridor, ou inventor de uma indústria util a propriedade e o uso exclusivo da sua descoberta, ou invenção.

Art. 2o O que melhorar uma descoberta, ou invenção, tem no melhoramento o direito de descobridor, ou inventor.

Art. 30 Ao introdutor de uma indústria estrangeira se dará um premio proporcionado á utilidade, e dificuldade da introdução.

\section{LEI 3.129, DE 14 DE OUTUBRO DE 1882}

Art. 1.o A lei garante pela concessão de uma patente ao autor de qualquer invenção ou descoberta a sua propriedade e uso exclusivo.

$\S 1$ 1 Constituem invenção ou descoberta para os efeitos desta lei:

1. A invenção de novos produtos industriais;

2 A invenção de novos meios ou a aplicação nova de meios conhecidos para se obter um produto ou resultado industrial;

3o O melhoramento de invenção já privilegiada, se tornar mais fácil o fabrico do produto ou uso do invento privilegiado, ou se lhe aumentar a utilidade.

(Sem correspondência direta. V., abaixo, o conteúdo do art. 2․)

(Art. 1으, continuação) Entendem-se por novos os produtos, meios, aplicações e melhoramentos industriais que até ao pedido da patente não tiverem sido, dentro ou fora do Império, empregados ou usados, nem se acharem descritos ou publicados de modo que possam ser empregados ou usados.

$\S 2$ ㅇ Não podem ser objeto de patente as invenções:

1 을 Contrarias á lei ou á moral;

20 Ofensivas da segurança publica;

3 ㅇ№civas á saúde pública;

4ำ As que não oferecerem resultado pratico industrial.

Art. 40 O direito do descobridor, ou inventor, será firmado por uma patente, concedida gratuitamente, pagando só o sello, e o feitio; e para conseguil-a:

1. Mostrará por escrito que a indústria, a que ser refere, é da sua própria invenção, ou descoberta.

20 Depositará no Arquivo Público uma exata e fiel exposição dos meios e processos, de que se serviu, com planos, desenhos ou modelos, que os esclareça, e se eles, se não puder ilustrar exatamente a matéria.

§ 3ㅇ A patente será concedida pelo Poder Executivo, depois de preenchidas as formalidades prescritas nesta lei e em seus regulamentos.

§ 40 O privilegio exclusivo da invenção principal só vigorará até 15 annos, e o do melhoramento da invenção concedido ao seu autor, terminará ao mesmo tempo que aquelle.
Art. 50 As patentes se concederão segundo a qualidade ${ }^{1}$ da descoberta ou invenção, por espaço de cinco até vinte annos: maior prazo só poderá ser concedido por lei.
${ }^{1} \mathrm{O}$ julgamento da qualidade implicava, necessariamente, o exame prévio, que seria abolido na legislação subsequente. 


$\mid$

Art. 60 Se o Governo comprar o segredo da invenção, ou descoberta, fal-o-ha publicar; no caso porém, de ter unicamente concedido patente, o segredo se conservará occulto até que expire o prazo da patente. Findo este, é obrigado o inventor ou descobridor a patentear o segredo.

Art. 70 $\mathrm{O}$ infractor do direito de patente perderá os instrumentos e productos, e pagará além disso uma multa igual á decima parte do valor dos productos fabricados, e as custas, ficando sempre sujeito á indemnização de perdas de damnos. Os instrumentos, e productos e a multa, serão applicados ao dono da patente.
(Inversão de Ordem)

(Art. 3.ㅇ, § 2.ㅇ, n. 3.ํ) Esceptuados sómente os casos mencionados no paragrapho antecedente, a patente será expedida, sem prévio exame.

(Art. 1) Si durante o privilegio, a necessidade ou utilidade publica exigir a vulgarisação da invenção, ou o seu uso exclusivo pelo Estado, poderá ser desapropriada a patente, mediante as formalidades legaes.

\section{(Inversão de Ordem)}

Art. 6. - Serão considerados infractores do privilegio: 10 Os que, sem licença, do concessionario, fabricarem os productos, ou empregarem os meios, ou fizerem as applicações que forem objecto da patente;

2o Os que importarem, venderem ou expuzerem á venda, occultarem ou receberem para o fim de serem vendidos productos contrafeitos da industria privilegiada, sabendo que o são.

$\S 1$ - Os infractores do privilegio serão punidos, em favor dos cofres publicos, com a multa de $500 \$$ a 5:000\$; e em favor do concessionario da patente, com 10 a $50 \%$ do damno causado ou que poderão causar. $\S 2$ o Serão consideradas circumstancias aggravantes: 10 Ser ou ter sido o infractor empregado ou operario nos estabelecimentos do concessionario da patente; 2o Associar-se o infractor com o empregado ou operario do concessionario, para ter conhecimento do modo pratico de obter-se ou empregar-se a invenção.

$\S$ 3ㅇ O conhecimento das infracções de privilegio compete aos Juizes de Direito das comarcas onde ellas se derem, os quaes expedirão, a requerimento do concessionario ou de seu legitimo representante, os mandadas de busca, apprehensão e deposito, e ordenarão as diligencias preparatorias ou instructivas do processo.

O julgamento será regulado pela Lei $n$. 562 , de 2 de Julho de 1850, e pelo Decreto n. 707 de 9 de Outubro do mesmo anno, no que forem applicaveis.

Os productos de que tratam os ns 1 e 2 deste artigo e os respectivos instrumentos e apparelhos serão adjudicados ao concessionario da patente, pela mesma sentença, que condemnar os autores das infracções.

$\S 4$ ㅇ $O$ processo não obstará a acção para o concessionario haver a indemnização do damno causado ou que se poderia causar.

§ 5ㅇ A jurisdicção commercial é competente para todas as causas relativas a privilegios industriaes, na conformidade desta lei.

$\S 6$ ㅇ Serão punidos com multa de $100 \$$ a $500 \$$, em favor dos cofres publicos:

10 Os que se inculcarem possuidores de patentes, usando de emblemas, marcas, lettreiros ou rotulos sobre productos ou objectos preparados para o commercio, ou expostos á venda, como si fossem privilegiados;

20 Os inventores que continuarem a exercer a industria como privilegiada, estando a patente suspensa, annullada ou caduca;

3o Os inventores privilegiados que, em prospectos, annuncios, lettreiros ou por qualquer modo de 


\begin{tabular}{|c|c|}
\hline & $\begin{array}{l}\text { publicidade fizerem menção das patentes, sem } \\
\text { designarem o objecto especial para que as tiverem } \\
\text { obtido; } \\
4 \text { o Os profissionaes ou peritos que na hypothese do } \S \\
2 \text { o, art. 3o, derem causa á vulgarisação do segredo da } \\
\text { invenção, sem prejuizo neste caso, das acções } \\
\text { criminaes ou civis que as leis permittirem. } \\
\S 70 \text { As infraçõos de que trata o paragrapho } \\
\text { antecedente serão processadas e julgadas como crimes } \\
\text { policiaes, na conformidade da legislação em vigor. }\end{array}$ \\
\hline \multirow[t]{2}{*}{$\begin{array}{l}\text { Art. 80 O que tiver uma patente, poderá dispor dela, } \\
\text { como bem lhe parecer, usando ele mesmo, ou } \\
\text { cedendo-a a um, ou a mais. }\end{array}$} & $\begin{array}{l}\text { (Inversão de Ordem) } \\
\text { Art. 7o Quando a patente fôr concedida a dous ou mais } \\
\text { coinventores, ou se tornar commum por titulo de } \\
\text { doação ou successão, cada um dos co-proprietarios } \\
\text { poderá usar della livremente. }\end{array}$ \\
\hline & $\begin{array}{l}\text { (Art. 1.o, } \S 5 . \text { ) A patente é transmissível por qualquer } \\
\text { dos modos de cessão ou transferência admitidos em } \\
\text { direito. }\end{array}$ \\
\hline \multirow[t]{2}{*}{$\begin{array}{l}\text { (Sem correspondência direta. Vide, acima, o conteúdo } \\
\text { do art. 3.‥) }\end{array}$} & 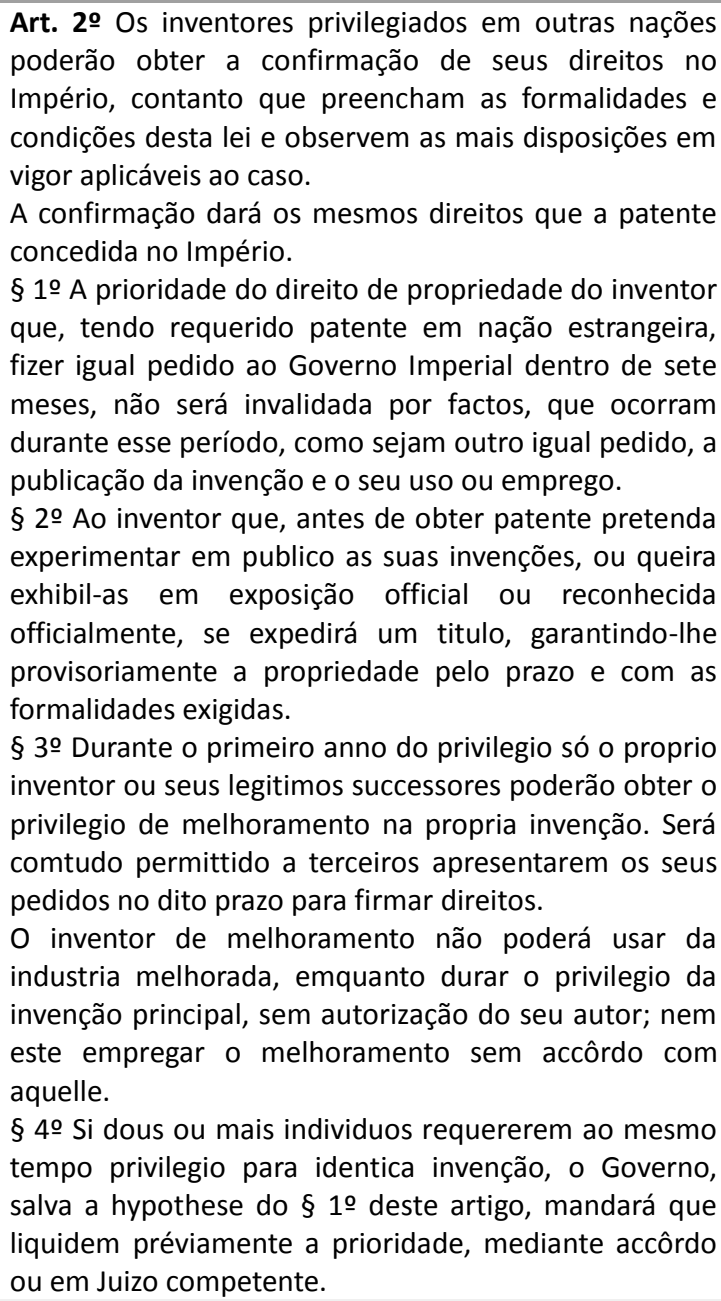 \\
\hline & $\begin{array}{l}\text { Art. 3o O inventor, que pretender patente, depositará } \\
\text { em duplicata, na repartição que o Governo designar, } \\
\text { sob envolucro fechado e lacrado, um relatorio em } \\
\text { lingua nacional, descrevendo com precisão e clareza a } \\
\text { invenção, o seu fim e modo de usal-a, com as plantas, } \\
\text { desenhos, modelos e amostras que sirvam para o } \\
\text { exacto conhecimento dessa invenção e intelligencia do } \\
\text { relatorio, de maneira que qualquer pessoa competente } \\
\text { na materia possa obter ou applicar o resultado, meio }\end{array}$ \\
\hline
\end{tabular}




\begin{tabular}{|c|c|}
\hline & 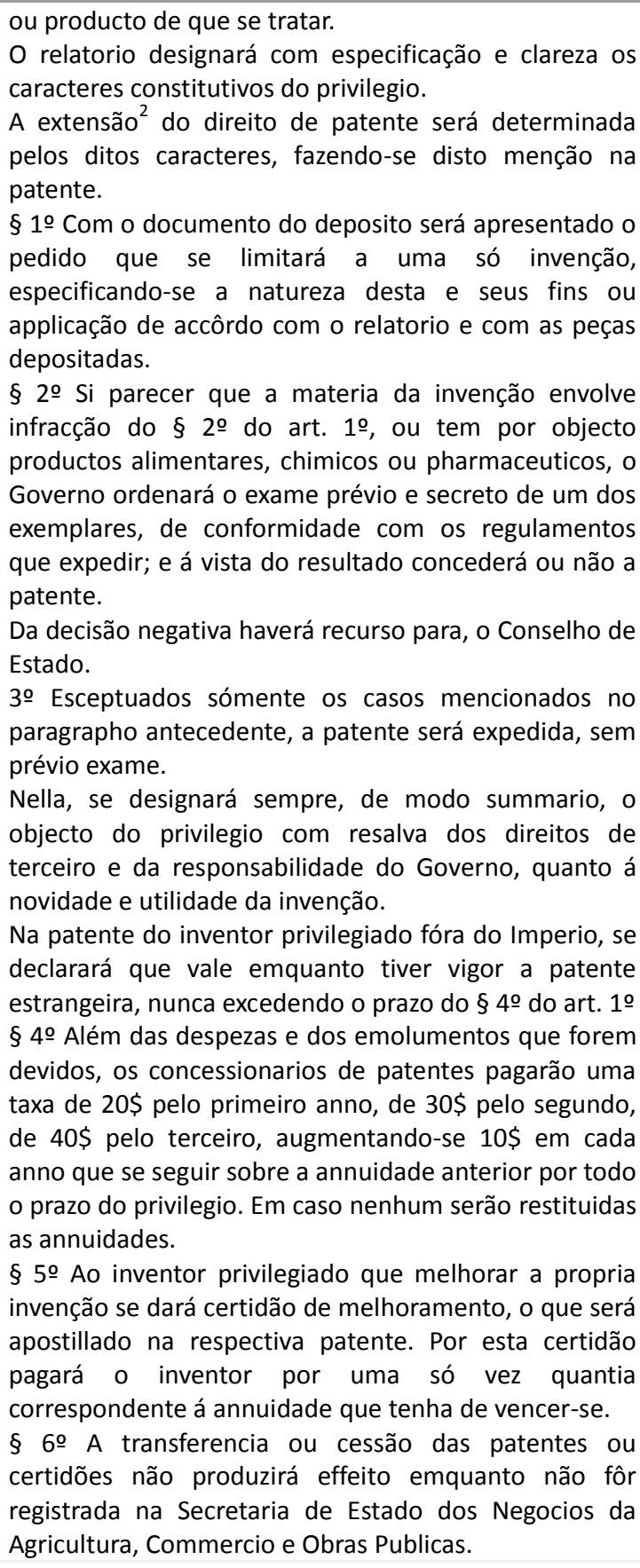 \\
\hline \multirow[t]{2}{*}{$\begin{array}{l}\text { Art. 9o No caso de se encontrarem dous, ou mais, nos } \\
\text { meios, por que tenham conseguido qualquer fim, e } \\
\text { coincidindo ao mesmo tempo em pedir a patente, esta } \\
\text { se concederá a todos. }\end{array}$} & $\begin{array}{l}\text { (Repetição de tópico já transcrito) } \\
\text { (Art. 2.o, § 4.@) Si dous ou mais individuos requererem } \\
\text { ao mesmo tempo privilegio para identica invenção, o } \\
\text { Governo, salva a hypothese do } \S 10 \text { deste artigo, } \\
\text { mandará que liquidem préviamente a prioridade, } \\
\text { mediante accôrdo ou em Juizo competente. }\end{array}$ \\
\hline & $\begin{array}{l}\text { Art. 40 Expedida a patente e dentro do prazo de } 30 \text { dias } \\
\text { se procederá com as formalidades que os regulamentos } \\
\text { marcarem á abertura dos envolucros depositados. } \\
\text { O relatorio será immediatamente publicado no Diario } \\
\text { Official, e um dos exemplares dos desenhos, plantas, } \\
\text { modelos ou amostras exposto á inspecção do publico e }\end{array}$ \\
\hline
\end{tabular}

${ }^{2}$ Disposição que vigora no direito moderno. 
Art. 10. Toda a patente cessa, e é nenhuma:

1ㅇ Provando-se que o agraciado faltou á verdade, ou foi diminuto, ocultando matéria essencial na exposição, ou declaração, que fez para obter a patente.

2o Provando-se a o que se diz inventor, ou descobridor, que a invenção, ou descoberta, se acha impressa, e descrita tal que ele a apresentou, como sua.

3o Se o agraciado não puzer em pratica a invenção, ou descoberta, dentro de dous annos depois de concedida a patente.

40 Se o descobridor, ou inventor, obteve pela mesma descoberta, ou invenção, patente em país estrangeiro. Neste caso porém terá, como introdutor, direito ao prêmio estabelecido no art. $3^{\circ}$.

5 o Se o gênero manufaturado, ou fabricado for reconhecido nocivo ao publico, ou contrario ás leis.

60 Cessa tambem o direito de patente para aqueles, que antes da concessão dela usavam do mesmo invento, ou descoberta. ${ }^{4}$ ao estudo dos interessados permittindo-se tirar cópias. Paragrapho unico. No caso de não ter havido o exame prévio de que trata $\circ \S 2 \circ$ do art. 3ㅇ, o Governo. publicado o relatorio, ordenará a verificação, por meio de experiencias, dos requisitos ${ }^{3}$ e das condições que a lei exige para a validade de privilegio, procedendo-se pelo modo estabelecido para aquelle exame.

Art. 50 A patente ficará sem effeito por nullidade ou caducidade.

$\S 1$ 을 Será nulla a patente:

10 Si na sua concessão se tiver infringido algumas das prescripções dos $\S \S 10$ e 2 어 do art. 10;

20 Si o concessionario não tiver tido a prioridade;

3o Si o concessionario tiver faltado á verdade ou occultado materia essencial no relatorio descriptivo da invenção, quanto ao seu objecto ou modo de usal-a; 4ㅇ Si a denominação da invenção fôr, com fim fraudulento, diversa do seu objecto real;

50 Si o melhoramento não tiver a indispensavel relação com a industria principal, e puder constituir industria separada, ou si tiver havido preterição da preferencia estabelecida pelo art. $2 \circ$ § 3 응

$\S 2$ 2 Caducará a patente nos seguintes casos:

10 Não fazendo o concessionario uso effectivo da invenção, dentro de tres annos, contados da data da patente;

20 Interrompendo o concessionario o uso effectivo da invenção por mais de um anno, salvo motivo de força maior, julgado procedente pelo Governo, com audiencia da respectiva Secção do Conselho de Estado; Entendo-se por uso, nestes dous casos, o effectivo exercicio da industria privilegiada e o fornecimento dos productos na proporção do seu emprego ou consumo. Provando-se que o fornecimento dos productos é evidentemente insufficiente para as exigencias do emprego ou consumo, poderá ser o privilegio restringido a uma zona determinada, por acto do Governo, com approvação do Poder Legislativo.

3o Não pagando o concessionario a annuidade nos prazos da lei;

4 Não constituindo o concessionario, residente fóra do Imperio, procurador para represental-o perante o Governo ou em Juizo;

50 Havendo renuncia, expressa da patente;

6- Cessando por qualquer causa a patente ou titulo estrangeiro sobre invenção, tambem privilegiada no Imperio;

70 Expirando o prazo do privilegio.

$\S$ 3ㅇ A nullidade da patente ou da certidão do melhoramento será declarada por sentença do Juizo Commercial da capital do Imperio, mediante o processo summario do Decreto n. 737, de 25 de Novembro de 1850.

São competentes para promover a acção de nullidade: O Procurador dos Feitos da Fazenda, e seus Ajudantes, aos quaes serão remettidos os documentos e peças comprobatorias da infracção;

\footnotetext{
${ }^{3}$ A ausência de exame prévio não significaria, porém, que os requisitos de validade não seriam analisados.
}

${ }^{4}$ Dispositivo que encontrou recepção inversa na Lei atual (usuário anterior). 


\begin{tabular}{|c|c|}
\hline & $\begin{array}{l}\text { E qualquer interessado, com assistencia daquelle } \\
\text { funccionario e seus ajudantes. } \\
\text { Iniciada a acção de nullidade nos casos do art. 10, } \S 2^{\circ} \text {, } \\
\text { ns. } 1,2 \text { e } 3 \text {, ficarão suspensos até final decisão os } \\
\text { effeitos da patente e o uso ou emprego da invenção. } \\
\text { Si não fôr annullada a patente, o concessionario será } \\
\text { restituido ao gozo della com a integridade do prazo do } \\
\text { privilegio. } \\
\S 4 \text { A caducidade das patentes será declarada pelo } \\
\text { Ministro e Secretario de Estado dos Negocios da } \\
\text { Agricultura, Commercio e Obras Publicas, com recurso } \\
\text { para o Conselho de Estado. }\end{array}$ \\
\hline & $\begin{array}{l}\text { Art. 80 Si a patente fôr dada ou deixada em usufructo, } \\
\text { será o usufructuario obrigado, quando o seu direito } \\
\text { cessar por extincção do usufructo ou terminação do } \\
\text { prazo do privilegio a dar ao senhor da nua propriedade } \\
\text { o valor em que esta fôr estimada, calculada com } \\
\text { relação ao tempo que durar o usufructo. }\end{array}$ \\
\hline & $\begin{array}{l}\text { Art. 9o As patentes de invenção já concedidas } \\
\text { continuam ser regidas pela Lei de } 28 \text { de Agosto de } \\
\text { 1830, sendo-lhes applicadas as disposições do art. 50, } \\
\text { §20, ns. } 1 \text { e 2, e do art. 60 da presente lei, com } \\
\text { excepção dos processos ou das aç̧ões pendentes. }\end{array}$ \\
\hline \multicolumn{2}{|l|}{$\begin{array}{l}\text { Art. 11. O Governo fica autorizado a mandar passar as } \\
\text { patentes, conformando-se com a disposição da } \\
\text { presente Lei, sendo sempre ouvido o Procurador da } \\
\text { Coroa, Fazenda e Soberania Nacional. }\end{array}$} \\
\hline $\begin{array}{l}\text { Art. 12. Ficam revogadas todas as Leis e disposições em } \\
\text { contrário. }\end{array}$ & Art. 10. Ficam revogadas as disposições em contrário. ${ }^{5}$ \\
\hline
\end{tabular}

${ }^{5}$ A grafia original foi mantida. 


\section{Quadro Comparativo (parcial) dos Códigos de 1967 e $1969^{1}$}

\begin{tabular}{|c|c|}
\hline DeCRETO-LEI 254, DE 28 DE FEVEREIRO DE 1967 & DeCreto-LeI 1.005, DE 21 dE OUTUBRo DE 1969 \\
\hline CÓDIGO DA PROPRIEDADE INDUSTRIAL & CÓDIGO DA PROPRIEDADE INDUSTRIAL \\
\hline $\begin{array}{l}\text { Art. 10 A proteção dos direitos reativos à propriedade } \\
\text { industrial se efetua mediante: } \\
\text { a) concessão de privilégios de patentes de invenção, de } \\
\text { desenhos e de modelos industriais; } \\
\text { b) concessão de registros de marcas de indústria e de } \\
\text { comércio ou de serviços, de nomes de emprêsa, de } \\
\text { títulos de estabelecimento, de insígnias, de expressões } \\
\text { ou sinais de propaganda e de recompensas industriais; } \\
\text { c) repressão a falsas indicações de proveniência; } \\
\text { d) repressão à concorrência desleal. }\end{array}$ & $\begin{array}{l}\text { Art. 10 A proteção dos direitos relativos à propriedade } \\
\text { industrial se efetua mediante: } \\
\text { a) concessão de privilégios: } \\
\text { de invenção; } \\
\text { de modelos industriais; e } \\
\text { de desenhos industriais; } \\
\text { b) concessão de registros: } \\
\text { de marcas de indústria, de comércio e de serviço; } \\
\text { de títulos de estabelecimento; e } \\
\text { de expressões ou sinais de propaganda; } \\
\text { c) repressão a falsas indicações de proveniência; } \\
\text { d) repressão à concorrência desleal. }\end{array}$ \\
\hline $\begin{array}{l}\text { Art. 2 As disposições deste Código são aplicáveis aos } \\
\text { pedidos diretamente depositados no Brasil e àqueles } \\
\text { que, embora depositados ou registrados no estrangeiro, } \\
\text { gozem de direitos assegurados por tratados ou } \\
\text { convenções. }\end{array}$ & $\begin{array}{l}\text { Art. 2o As disposições deste Código são aplicáveis } \\
\text { também aos pedidos de privilégio e de registros } \\
\text { depositados no estrangeiro e que tenham proteção } \\
\text { assegurada por tratados ou convenções de que o Brasil } \\
\text { seja signatário, desde que depositados regularmente no } \\
\text { País. }\end{array}$ \\
\hline $\begin{array}{l}\text { Art. 3o Toda pessoa física ou jurídica poderá, } \\
\text { administrativa ou judicialmente, solicitar a aplicação, } \\
\text { em igualdade de condições, de qualquer dispositivo de } \\
\text { tratados ou convenções que estabeleçam situação } \\
\text { vantajosa para as pessoas físicas ou jurídicas } \\
\text { domiciliadas no exterior. }\end{array}$ & $\begin{array}{l}\text { Art. 3o Toda pessoa física ou jurídica, domiciliada no } \\
\text { Brasil, com legítimo interesse, poderá, administrativa } \\
\text { ou judicialmente, solicitar a aplicação, em igualdade de } \\
\text { condições, de qualquer dispositivo de tratados ou } \\
\text { convenções a que o Brasil aderir. }\end{array}$ \\
\hline $\begin{array}{c}\text { TíTULO I } \\
\text { DOS PRIVILÉGIOS DE INVENÇÃo }\end{array}$ & $\begin{array}{c}\text { TíTULO I } \\
\text { Dos PRIVILÉGIOS }\end{array}$ \\
\hline $\begin{array}{c}\text { CAPÍTULO I } \\
\text { DAS PATENTES de INVENÇão }\end{array}$ & $\begin{array}{c}\text { CAPÍTULO I } \\
\text { DISPOSIÇõES GERAIS }\end{array}$ \\
\hline $\begin{array}{c}\text { SEÇÃO I } \\
\text { DISPOSIÇÕES GERAIS }\end{array}$ & $\begin{array}{c}\text { SEÇÃO I } \\
\text { DOS AUTORES OU REQUERENTE }\end{array}$ \\
\hline $\begin{array}{l}\text { Art. 4. Aos autores de invenção nova suscetível de } \\
\text { exploração industrial será assegurado o direito de obter } \\
\text { patente que lhes garanta sua propriedade e uso } \\
\text { exclusivo, nas condições estabelecidas neste Código. } \\
\S 1 \text {. Para o efeito de concessão de patente, presume-se } \\
\text { autor o requerente do privilégio. }{ }^{2} \\
\S 20 \text { As pessoas jurídicas poderão requerer privilégios }\end{array}$ & $\begin{array}{l}\text { Art. 4o Aos autores de invenção, de modelo industrial e } \\
\text { de desenho industrial, será assegurado o direito de } \\
\text { obter patente que lhes garanta a propriedade e o uso } \\
\text { exclusivo, nas condições estabelecidas neste Código. } \\
\S 1 \text { 10 Para efeito de concessão de patente, presume-se } \\
\text { autor o requerente do privilégio. } \\
\S 20 \text { O privilégio poderá ser requerido pelo autor da }\end{array}$ \\
\hline
\end{tabular}

${ }^{1} \mathrm{O}$ que se extrai, da leitura de ambos os textos, são vários e vários artigos procedimentais, com muito pouco relacionado ao direito do inventor fora do sistema de patentes. São quase infindáveis considerações relativas a elementos administrativo-processuais para pouquíssima ocupação com o cerne da matéria.

${ }^{2}$ Abandona-se aqui o princípio da invenção ao inventor. 
de invenção, desde que autorizadas expressamente pelo seu inventor. invenção, seus herdeiros e sucessores, pessoas jurídicas autorizadas ou eventuais cessionários dos respectivos direitos, mediante apresentação de documento hábil, dispensada a legalização ou a autenticação do mesmo. $\S 3$ Em caso de invenção por duas ou mais pessoas, em conjunto, o privilégio poderá ser requerido por todas ou qualquer delas, ressalvados os respectivos direitos, mediante nomeação e qualificação de todos os inventores.

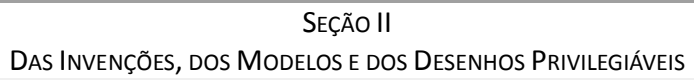

Art. 5o É privilegiável toda invenção nova suscetível de utilização industrial.

$\S 1$ o Considera-se nova, e assim privilegiável, a invenção que, até a data do depósito do pedido de patente, não tenha sido depositada, patenteada, divulgada ou explorada no País, nem patenteada, divulgada ou explorada no estrangeiro.

$\S 2$ 2 Para o efeito de concessão de patente, o exame da novidade da invenção restringir-se-á às alegações e provas constantes das oposições oferecidas ou dos laudos emitidos por órgãos técnicos.

Art. 60 São ainda privilegiáveis:

a) os produtos novos desde que, através de análises ou outros exames técnicos adequados, revelarem, pelas suas propriedades intrínsecas, o processo de que são oriundos;

b) os processos novos destinados à fabricação de substâncias, produtos ou materiais neles mencionados; c) as ligas metálicas e, bem assim, as misturas com qualidades específicas perfeitamente caracterizadas pelas suas composições qualitativas e quantitativas;

d) a justaposição de órgãos, peças ou partes conhecidos, a mudança de forma, proporções, dimensões ou de materiais, quando daí resultar no conjunto nôvo efeito técnico, ou representar solução original de problema técnico ou invenção que introduza vantagens práticas e econômicas.

SEÇão III
DAS INVENÇõES NÃO PRIVILEGIÁVEIS

Art. 70 Não são patenteáveis como privilégio de invenção:

a) as invenções contrárias à lei, à moral, à saúde e à segurança públicas;

b) as invenções que tiverem por objeto substâncias ou produtos alimentícios e medicamentos de qualquer espécie;

c) as invenções que tiverem por objeto matérias ou substâncias ou produtos alimentícios e medicamentos de qualquer espécie; ${ }^{3}$

d) as concepções puramente teóricas;

e) a simples justaposição de órgãos, peças ou partes conhecidos ou a simples mudança de forma, proporções, dimensões ou de materiais;
Art. 50 São privilegiáveis a invenção, o modelo industrial e o desenho industrial considerados novos e suscetíveis de utilização industrial.

Parágrafo único. Consideram-se novos a invenção, o modelo e o desenho que, até a data do depósito do pedido de patente, não tenham sido depositados, patenteados, divulgados ou explorados no Brasil, nem patenteados, divulgados ou explorados no estrangeiro, ressalvado o disposto nos arts. 60 e 17 do presente Código.

Art. 80 Não são privilegiáveis:
a) as invenções de finalidade contrária às leis, à moral, à
saúde, à segurança pública, aos cultos religiosos e aos
sentimentos dignos de respeito e veneração;
b) as substâncias, matérias ou produtos obtidos por
meios ou processos químicos, ressalvando-se, porém, a
privilegiabilidade dos respectivos processos de
obtenção ou modificação;
c) as substâncias, matérias, misturas ou produtos
alimentícios, químico-farmacêuticos e medicamentos,
de qualquer espécie, bem como os respectivos
processos de obtenção ou modificação;
d) as misturas e ligas metálicas em geral, ressalvando-
se, porém, as que, não compreendidas na alínea

(INVERSÃO DE ORDEM)

CAPÍTULO II

DAS INVEnçõ̃es Não PRIVILEGIÁVEIS 
f) os sistemas de escrituração comercial e de cálculo, os sistemas e planos ou esquemas de financiamento, de crédito, de sorteio, especulação ou propaganda.

anterior, apresentarem qualidades intrínsecas específicas, precisamente caracterizadas pela sua composição qualitativa, definida quantitativamente, ou por tratamento especial a que tenham sido submetidas; e) as justaposições de processos, meios ou órgãos conhecidos, a simples mudança de forma, proporções, dimensões ou de materiais, salvo se daí resultar, no conjunto, um efeito técnico nôvo ou diferente, não compreendido nas proibições das alíneas anteriores, ou se tratar de invenções que constituam objetos que se prestem a trabalho ou uso prático e tragam à função a que se destinam melhor utilização;

f) os usos ou empregos relacionados com descobertas, inclusive de variedades ou espécies de microrganismos, para fim determinado;

g) as técnicas operatórias ou cirúrgicas ou de terapêutica, não incluídos os dispositivos, aparelhos ou máquinas;

h) os sistemas, os planos ou os esquemas de escrituração comercial, de cálculos, de financiamento, de crédito, de sorteios, de especulação ou de propaganda;

i) as concepções puramente teóricas.

SEÇÃO IV

DA GARANTIA DE PRIORIDADE

\section{(INVERSÃO DE ORDEM) SEÇÃO III \\ (Do CAPÍTULO I, TÍtULO I) \\ Da GaRANTIA de PRIORIDAde}

Art. 8o Aquêle que, antes de requerer patente para a sua invenção, pretenda fazer experiências, comunicações a associações científicas ou exibições do invento, em exposições oficiais ou oficialmente reconhecidas, deverá requerer ao Departamento Nacional da Propriedade Industrial garantia de prioridade, apresentando relatório descritivo e desenhos, quando fôr o caso, de sua invenção, e a prova de haver pago a taxa correspondente.

$\S 1$ Dêsse ato lavrar-se-á têrmo de depósito, vigorando desde então a garantia de prioridade por um ano.

$\S$ 2ㅇ Dentro dêsse prazo deverá o interessado apresentar o pedido de privilégio de invenção, prevalecendo o número e a data do têrmo de depósito, a que se refere o parágrafo anterior, nas condições e para os efeitos dos artigos 15 e 17 .

$\S 3$ O 0 pedido de garantia de prioridade dispensa as formalidades de exame e publicação, que serão aplicáveis, entretanto, ao pedido de privilégio de invenção.

$\S 4$ ㅇ Findo o prazo de um ano, sem que o interessado tenha requerido a patente, decairá automàticamente da garantia de prioridade, ficando o pedido respectivo sem efeito para qualquer fim.

§ 5o O Diretor Geral do Departamento Nacional da Propriedade Industrial poderá cancelar a garantia de prioridade, a requerimento de qualquer interessado que prove haver o inventor explorado, com fins lucrativos, o objeto da invenção.

$\S$ 60 Da decisão do Diretor Geral do Departamento Nacional da Propriedade Industrial caberá recurso dos interessados dentro do prazo de noventa dias, contados da publicação daquela decisão, ficando sobrestado o andamento do processo relativo ao pedido de privilégio de invenção, se tiver sido iniciado, até a decisão final do
Art. 60 Aquêle que, antes de requerer patente, pretenda fazer demonstrações, comunicações a associações científicas ou exibições do invento em exposições oficiais ou oficialmente reconhecidas, deverá, para ressalva de prioridade, requerer ao Departamento Nacional da Propriedade Industrial a respectiva garantia, apresentando relatório descritivo circunstanciado, bem como os desenhos, quando fôr o caso, e a prova de haver pago a taxa correspondente.

$\S 1$ 10 Dêsse ato lavrar-se-á têrmo de depósito, vigorando desde então a garantia de prioridade por um ano, para os casos de invenção e por seis meses para os de modêlo e desenho.

$\S 2$ 2 Dentro dêsses prazos deverá o interessado depositar o pedido de privilégio, nas condições e para os efeitos dos artigos 13 e 15, prevalecendo a data do têrmo de depósito a que se refere o parágrafo anterior. $\S$ 3ㅇ 0 pedido de garantia de prioridade dispensa as formalidades de exame e publicação, que serão aplicáveis, entretanto, ao respectivo pedido de privilégio. 


\begin{tabular}{|c|c|}
\hline & \\
\hline & $\begin{array}{l}\text { Art. 70 Findos os prazos estabelecidos no } \S 1 \text {, sem que } \\
\text { o interessado tenha requerido o privilégio, extinguir-se- } \\
\text { á automàticamente a garantia de prioridade, } \\
\text { considerando-se do domínio público o que tenha sido } \\
\text { objeto de requerimento. }\end{array}$ \\
\hline $\begin{array}{c}\text { CAPítUlo III } \\
\text { Dos Pedidos de Patente de INVEnção, Desenhos e Modêlos } \\
\text { INDUSTRIAL }\end{array}$ & $\begin{array}{c}\text { CAPÍtUlo IV } \\
\text { Dos Pedidos de PRIVILÉGIO }\end{array}$ \\
\hline $\begin{array}{l}\text { Art. 15. O pretendente a privilégios de invenção, } \\
\text { desenho ou modêlo industrial deverá depositar, no } \\
\text { Departamento Nacional da Propriedade Industrial, o } \\
\text { seu pedido acompanhado do relatório descritivo da } \\
\text { invenção com os respectivos desenhos, quando fôr o } \\
\text { caso. } \\
\S 1 \text { o O pedido, que deve compreender sòmente uma } \\
\text { invenção, será formulado em requerimento dirigido ao } \\
\text { Diretor Geral do Departamento mencionando, } \\
\text { precisamente, o nome do inventor, por extenso, sua } \\
\text { nacionalidade, profissão, domicílio e nome e domicílio } \\
\text { do seu procurador, se houver. } \\
\S 2 \text { o O relatório deverá ser escrito em português e } \\
\text { descrever, de maneira precisa e clara, a invenção, sua } \\
\text { destinação e a maneira de usá-la e satisfazer, ainda, as } \\
\text { seguintes condições: } \\
\text { a) conter a descrição do invento e expor, } \\
\text { pormenorizadamente, sem reservas ou omissões, o } \\
\text { problema técnico que o mesmo visa a resolver, sua } \\
\text { execução e funcionamento; } \\
\text { b) apresentar resumo que defina, com clareza, os } \\
\text { pontos característicos da invenção, os quais servirão } \\
\text { para estabelecer e delimitar os direitos do inventor. } \\
\S 3 \text { o Os desenhos deverão conter, no espaço limitado } \\
\text { pela moldura, as figuras em tamanho estritamente } \\
\text { necessário, de maneira que se possam distinguir umas } \\
\text { das outras e permitir o fácil conhecimento das minúcias. } \\
\S 4 \text { A A patente poderá ser requerida pelo autor da } \\
\text { invenção ou eventuais cessionários dos respectivos } \\
\text { direitos, mediante apresentação de documento hábil. }\end{array}$ & $\begin{array}{l}\text { Art. 13. O pretendente a privilégios de invenção, de } \\
\text { modêlo ou de desenho industrial deverá apresentar o } \\
\text { seu pedido ao Diretor-Geral do Departamento Nacional } \\
\text { da Propriedade Industrial, acompanhado do relatório } \\
\text { descritivo, com os respectivos desenhos, quando fôr o } \\
\text { caso. } \\
\S 1 \text { o o requerimento, que só poderá referir-se a uma } \\
\text { única invenção, especificando sempre sua natureza, } \\
\text { deverá conter o respectivo título explicativo da } \\
\text { invenção, o qual será o mesmo do relatório, bem como } \\
\text { a qualificação completa do requerente e de seu } \\
\text { procurador, se houver. } \\
\S 2 \text { o O relatório, sempre escrito em português, deverá } \\
\text { satisfazer às seguintes condições: } \\
\text { a) descrever, de maneira clara e precisa, a invenção, de } \\
\text { modo que o técnico no assunto possa realizá-la; indicar } \\
\text { sua natureza e sua finalidade e conter o título } \\
\text { explicativo da invenção, o qual deverá ser o mesmo do } \\
\text { requerimento; } \\
\text { b) apresentar com clareza os pontos característicos da } \\
\text { invenção, os quais servirão para estabelecer e delimitar } \\
\text { os direitos do inventor; } \\
\text { c) apresentar desenhos, quando necessário. }\end{array}$ \\
\hline $\begin{array}{l}\text { Art. 16. Sempre que o inventor quiser garantir, } \\
\text { isoladamente, qualquer particularidade de sua } \\
\text { invenção, poderá requerê-la em pedido separado, } \\
\text { desde que não faça parte de conjunto indivisível. }\end{array}$ & $\begin{array}{l}\text { Art. 14. Sempre que o inventor quiser garantir } \\
\text { isoladamente qualquer particularidade de sua } \\
\text { invenção, poderá requerê-la em pedido separado, } \\
\text { desde que possa ser destacada do conjunto e não tenha } \\
\text { sido, antes, descrita pormenorizadamente. }\end{array}$ \\
\hline $\begin{array}{c}\text { CAPítUlo IV } \\
\text { Do DePósito dos PEDIDOS de Patentes }\end{array}$ & $\begin{array}{c}\text { CAPÍTULO V } \\
\text { Do Depósito dos PEDIDOS DE PRIVILÉGIO }\end{array}$ \\
\hline $\begin{array}{l}\text { Art. 17. Apresentado o pedido, lavrar-se-á o respectivo } \\
\text { têrmo de depósito assinado pelo inventor, ou seu } \\
\text { procurador, e pelo funcionário encarregado. } \\
\text { Parágrafo único. Do têrmo de depósito constarão a data } \\
\text { da apresentação do pedido mencionando-se hora, dia, } \\
\text { mês e ano, o nome do requerente e do seu procurador, } \\
\text { quando houver, podendo dêle ser fornecida certidão ao } \\
\text { depositante, mediante pagamento da taxa estipulada. }\end{array}$ & $\begin{array}{l}\text { Art. 15. Apresentado o pedido, devidamente instruído e } \\
\text { com a comprovação do pagamento da taxa } \\
\text { correspondente, lavrar-se-á o respectivo têrmo de } \\
\text { depósito, que deverá ser assinado pelo requerente, ou } \\
\text { seu procurador, e pelo funcionário encarregado. } \\
\text { Parágrafo único. Do têrmo de depósito constarão hora, } \\
\text { dia, mês, ano e número de ordem da apresentação do } \\
\text { pedido, título e natureza da invenção, indicação de } \\
\text { prioridade, quando reivindicada, e nome do requerente } \\
\text { e de seu procurador, se houver, sendo fornecida } \\
\text { certidão ao depositante, mediante pagamento da taxa } \\
\text { devida. }\end{array}$ \\
\hline $\begin{array}{l}\text { Art. 18. Exclusivamente para o efeito de prioridade } \\
\text { poderão ser recebidos pelas Delegacias Estaduais do } \\
\text { Ministério da Indústria e do Comércio os pedidos }\end{array}$ & $\begin{array}{l}\text { Art. 16. Sòmente os pedidos de garantia de prioridade e } \\
\text { os iniciais de privilégio, bem como as petições de } \\
\text { cumprimento de exigências por partes que não tenham }\end{array}$ \\
\hline
\end{tabular}


iniciais de privilégios de patentes de invenção, de desenho ou de modêlo industrial, lavrando-se os respectivos têrmos de depósito, dos quais constarão a hora, dia, mês e ano da apresentação do pedido e as assinaturas do inventor ou de seu curador e do funcionário designado pelo respectivo Delegado.

Parágrafo único. Lavrado o têrmo de depósito, a Delegacia providenciará a remessa da documentação respectiva ao Departamento Nacional da Propriedade Industrial, dentro de cinco dias, contados da data do referido têrmo.

CApítulo V
Dos Depósitos Feitos no Estrangeiro

Art. 19. O inventor que tiver depositado, regularmente, em Estado com o qual o Brasil mantenha convenção ou tratado, pedido de privilégio de patente de invenção, de desenho ou de modêlo industrial, gozará, ao apresentar igual pedido no Brasil, do direito de prioridade pelo prazo estipulado na respectiva convenção ou tratado. A prioridade em nenhum caso poderá ser invalidada por fatos ocorridos durante êsse prazo, tais como pedido idêntico, publicação da invenção do modêlo ou do desenho, seu uso ou exploração.

$\S 100$ prazo de prioridade ficará averbado na patente, se o interessado, por ocasião de requerê-la no Brasil, reivindicar os benefícios decorrentes de pedido anterior, comprovando-a com o certificado de depósito no país de origem ou a respectiva patente.

$\S 20$ A apresentação dos comprovantes referidos no parágrafo anterior deverá ser feita no prazo máximo de noventa dias.

§ 3o Além do certificado de depósito, poderão ser exigidos relatórios, desenhos ou outros documentos que a repartição julgue necessários ao exame do pedido.

$\S 4$ 은 No caso da patente estrangeira sofrer redução qualitativa ou quantitativa em seus pontos característicos, relatórios ou desenhos, o pedido efetuado no Brasil deverá se correspondentemente retificado, sob pena de nulidade da patente.

CAPítulo VI
Do Exame Formal e Técnico e do Processamento do Pedido

Art. 20. Lavrado o têrmo de depósito do pedido, o respectivo processo será submetido, de imediato, ao exame formal e de verificação da natureza da invenção e de sua conformidade com as prescrições regulamentares, providenciando-se, concomitantemente, a publicação dos respetivos pontos característicos e desenhos, quando houver.

$\S 1$ 을 Verificado, pelo exame formal e técnico, que o processo está incompleto ou em desacôrdo com as normas aplicáveis, será o interessado notificado a regularizá-lo dentro do prazo de noventa dias.

$\S$ 2ㅇ Verificando o Departamento Nacional de Propriedade Industrial que o pedido ainda se encontra incompleto, notificará o interessado, em qualquer caso, e o seu procurador, se houver, pela segunda e última vez a regularizar o processo, dentro de nôvo prazo de noventa dias, contado igualmente da data da publicação do despacho respectivo. procurador junto ao Departamento Nacional da Propriedade Industrial, poderão ser apresentados também nas Delegacias Estaduais do Ministério da Indústria e do Comércio, lavrando-se os respectivos têrmos de depósito, nos dois primeiros casos, na forma do artigo 15 e seu parágrafo único.

Parágrafo único. Lavrado o têrmo de depósito, ou recebida a petição de cumprimento de exigências, a Delegacia providenciará a remessa da documentação respectiva ao Departamento Nacional da Propriedade Industrial, dentro de cinco dias, contados da data do recebimento.

\section{Dos Depósitos Feitos no Estrangeiro}

Art. 17. Ao inventor que tiver depositado, regularmente, em Estado com o qual o Brasil mantenha acôrdo internacional, pedido de privilégio de invenção, de modêlo ou de desenho industrial, ficará assegurado direito de prioridade para apresentar igual pedido no Brasil, pelo prazo estimulado no respectivo acôrdo. A prioridade em nenhum caso poderá ser invalidada por fatos ocorridos durante êsse prazo, tais como pedido idêntico, publicação da invenção, do modêlo ou do desenho, seu uso, exploração ou concessão da patente. $\S 1$ ㅇ A reivindicação de prioridade será averbada no têrmo de depósito e constará da patente a ser expedida, desde que comprovado o respectivo direito, mediante apresentação de certificado do depósito do pedido no país de origem ou da patente, de certidão ou cópia autenticada de um dêstes documentos.

$\S 2$ ㅇ A apresentação do comprovante mencionado no parágrafo anterior deverá ser feita no prazo máximo de noventa dias, contado da data do depósito do pedido, sob pena de perda do direito de prioridade.

\section{Do Exame Formal e Técnico dos Pedidos de PriviléGio}

Art. 18. Lavrado o têrmo de depósito, o processo será submetido a exame formal e a exame técnico preliminar, de conformidade com as prescrições regulamentares, mantendo-se em sigilo até seu arquivamento definitivo ou a publicação dos pontos característicos, ressalvado o direito de vista a quem o requeira, quando o processo tenha sido apontado como colidente com o seu pedido.

$\S 1$ 을 Verificado, quer pelo exame formal, quer pelo exame técnico preliminar, que o processo está em desacôrdo com as normas aplicáveis, será notificado o interessado ou seu procurador, se houver, para regularizá-lo, cumprindo ou contestando a exigência, dentro do prazo de sessenta dias, contado da data da notificação.

$\S 2$ 을 Esgotado o prazo a que se refere o parágrafo anterior, sem que o interessado tenha promovido o completo saneamento do processo, incidirá êste em 
$\S 3$ ㅇ Esgotados os prazos a que se referem os parágrafos anteriores, sem que o interessado promova o saneamento do processo, incidirá êste em arquivamento, de cujo despacho só caberá recurso, dentro do prazo de noventa dias, da respectiva publicação em caso de êrro comprovado do Departamento Nacional da Propriedade Industrial. arquivamento, de cujo despacho caberá pedido de reconsideração ao Diretor-Geral do Departamento Nacional da Propriedade Industrial, desde que satisfeita ou contestada a exigência, concomitantemente com o requerimento, dentro do prazo de sessenta dias da data da notificação do arquivamento.

§ 3ํㅡㄹ caso de não cumprimento da exigência formal, ou de ser improcedente a contestação à mesma, o processo será definitivamente arquivado, de cujo despacho não caberá qualquer recurso administrativo. $\S 4$ ㅇ Em caso de não cumprimento de exigência técnica, mas de contestação à mesma, do despacho do DiretorGeral do Departamento sôbre o pedido de reconsideração caberá recurso ao Ministro da Indústria e do Comércio, dentro do prazo de sessenta dias.

$\S 5$ o Se o despacho do Ministro confirmar a decisão recorrida, encerrar-se-á a fase administrativa; em caso contrário, o processo terá prosseguimento.

Art. 19. Por ocasião do exame técnico preliminar será verificado, desde logo, se o pedido infringe as disposições dos artigos 8o e 12 dêste Código, se há anterioridade e se está tècnicamente bem definido, a fim de se apurar a viabilidade de privilégio.

$\S 10$ Quando o parecer fôr denegatório, o técnico indicará as anterioridades ou as colidências que forem encontradas, assim como outras razões que o levaram a considerar imprivilegiável o pedido.

$\S 2$ ㅇ Nas condições do parágrafo anterior, o pedido poderá ser desde logo indeferido, sem necessidade de formulação de exigências, e de publicação de pontos característicos e de cópia dos desenhos.

§ 3ㅇ Do despacho denegatório previsto no parágrafo anterior caberá pedido de reconsideração ao DiretorGeral do Departamento Nacional da Propriedade Industrial, no prazo de sessenta dias.

§ 40 Se o Diretor-Geral do Departamento mantiver o despacho denegatório previsto no $\S 20$, caberá recurso ao Ministro da Indústria e do Comércio, no prazo de sessenta dias.

$\S$ 5o Se o despacho do Ministro confirmar a decisão recorrida, encerrar-se-á a fase administrativa; em caso contrário, o processo terá prosseguimento, de conformidade com os artigos 20 e seguintes.

Art. 21. Durante o prazo de noventa dias, a contar da data da publicação definitiva dos pontos característicos e dos desenhos serão admitidas oposições de terceiros à concessão do privilégio.

$\S 1$ 10 Publicadas as oposições manifestadas, o depositante poderá oferecer réplica no prazo de noventa dias.

§ 2 - Findo o prazo de réplica e ainda que na ausência desta e de oposições, o processo será submetido, nos noventa dias subseqüentes, à perícia a ser realizada por técnicos credenciados nos têrmos do art. 151, os quais poderão solicitar ao inventor os esclarecimentos que julgarem necessários.

§ 3 Concluído o exame técnico, o processo será submetido a despacho do Diretor-Geral do Departamento Nacional da Propriedade Industrial.

$\S$ 4을 Do despacho concessivo ou denegatório do privilégio caberá recurso para o Conselho de Recursos da Propriedade Industrial, dentro dos noventa dias
Art. 20. Verificado, pelo exame técnico preliminar, que há viabilidade de privilégio, será publicado pelo menos um ponto característico da invenção, citando-se o total de pontos, acompanhado de cópia de pelo menos, um desenho, e da indicação de prioridade, se houver, para apresentação de eventuais oposições pelos interessados, dentro do prazo de sessenta dias.

Parágrafo único. Da data da notificação da oposição correrá o prazo de sessenta dias para apresentação da réplica. 
seguintes à data da publicação daquele despacho. $\S 5$ ㅇ Nos noventa dias subseqüentes à data da interposição do recurso perante o Conselho, poderá o interessado oferecer réplica.

$\S$ 60 Não se admitirá recurso contra despacho denegatório que tenha sido proferido com base nos artigos 70 exceto alínea e, e 14, exceto alíneas b e c.

§ 70 Na ausência de oposições, expirado o prazo para êsse fim estabelecido neste artigo, e concedido o privilégio, do despacho respectivo não caberá qualquer recurso administrativo.

Art. 21. Não sendo apresentada oposição, o pedido poderá ser deferido e do despacho de deferimento não caberá qualquer recurso administrativo.

$\S 1$ 을 No caso do indeferimento do pedido, decorrente de condição impeditiva argüida pelo próprio Departamento Nacional da Propriedade Industrial, caberá pedido de reconsideração ao seu Diretor-Geral, no prazo de sessenta dias.

$\S$ 2o Da decisão do Diretor-Geral que mantiver o despacho de indeferimento caberá recurso, no prazo de sessenta dias, ao Conselho de Recursos da Propriedade Industrial.

§ 3으 Da data da notificação do recurso correrá o prazo de sessenta dias para apresentação de réplica.

Art. 22. Surgindo oposição, proceder-se-á ao exame técnico complementar, podendo ser solicitada pelo Departamento Nacional da Propriedade Industrial, em caráter supletivo, a audiência de outros serviços técnicos, seja da Administração Pública, seja de organizações reconhecidas pelo Govêrno como órgãos de consulta, seja de membros dos corpos docentes das universidades de ensino superior, mediante o pagamento de "pro-labore" ao técnico credenciado. Parágrafo único. O encarregado do exame técnico poderá solicitar, fundamentando a exigência, os esclarecimentos que julgar necessários, bem como novos relatórios descritivos, pontos característicos e desenhos, aplicando-se o disposto no artigo 18 e seus parágrafos.

Art. 23. Concluído o exame técnico, do despacho do Diretor-Geral do Departamento Nacional da Propriedade Industrial caberá recurso para o Conselho de Recursos da Propriedade Industrial, dentro do prazo de sessenta dias.

Parágrafo único. Da data da notificação do recurso correrá o prazo de sessenta dias para apresentação de réplica.

Art. 24. Quando houver pedido correspondente para a mesma invenção, depositada ou concedida em país estrangeiro, o requerente, sempre que solicitado, fundamentadamente, pelo Departamento, será obrigado a comunicar tôdas as objeções formuladas contra aquêle pedido.

\section{CAPÍTULO VII \\ DA EXPEDIÇÃO dAS PATENTES}

Art. 22. Concedido afinal o privilégio, será publicado o despacho respectivo e expedido e entregue ao requerente ou seu procurador a carta-patente do invento, contra recibo e comprovação do pagamento de taxa devida.

$\S 1$ 10 Não sendo paga a taxa devida e retirada a cartapatente no prazo improrrogável de noventa dias da data

\section{DA EXPEDIÇÃO DAS PATENTES}

Art. 25. Transitada em julgado a decisão concessiva do privilégio, será iniciado o decurso do prazo de sessenta dias para pagamento concomitante da taxa de expedição da patente e da primeira anuidade de duração da mesma, independentemente de qualquer notificação.

§ 10 Não sendo comprovado, junto ao Departamento Nacional da Propriedade Industrial, o pagamento de qualquer das referidas taxas, dentro do prazo dêste 
da expedição desta, será cancelado o privilégio e arquivado o processo respectivo, mediante despacho irrecorrível do Diretor-Geral do Departamento Nacional da Propriedade Industrial, a ser proferido dentro dos trinta dias seguintes à data da expiração daquele prazo.

$\S$ 2 Da carta-patente deverão constar o número respectivo, o nome, nacionalidade, profissão e domicílio do inventor, ou de seu sucessor, o nome e domicílio de seu representante ou procurador, quando houver, o título de invenção e o prazo de sua duração, anexandose-lhe uma das vias do relatório definitivo e dos desenhos.

Art. 23. No Departamento Nacional da Propriedade Industrial existirão registros próprios para as patentes de invenção, para os modelos industriais, para os desenhos industriais e para as prioridades estrangeiras reivindicadas no Brasil, cada um com numeração específica.

Parágrafo único. Os privilégios de invenção, que forem comcedidos pelo Departamento Nacional da Propriedade Industrial, terão a mais ampla divulgação possível através de publicação no órgão oficial do mesmo Departamento e em outros meios de comunicação mediante convênios com entidades governamentais ou entidades de classe. artigo, será arquivado o processo, facultada a respectiva restauração, mediante petição ao Diretor-Geral do Departamento Nacional da Propriedade Industrial, apresentada dentro dos trinta dias seguintes à data da publicação do despacho de arquivamento e acompanhada de prova do pagamento daquelas taxas e da de restauração.

§ 2ㅇ Comprovado o pagamento das taxas devidas, será a patente entregue ao requerente ou a seu procurador, mediante recibo.

$\S 3$ ㅇ Da patente deverão constar o número respectivo, nome, nacionalidade, profissão e domicílio do inventor, de seu sucessor ou cessionário, se houver, o título da invenção e o prazo de sua duração, ressalvando-se os direitos de terceiros e a responsabilidade do Governo quanto à novidade e à utilidade da invenção, anexandose-lhe uma das vias do relatório definitivo, bem como dos desenhos, se houver.

Art. 26. No Departamento Nacional da Propriedade Industrial existirão registros próprios para as patentes de invenção, para as de modêlo industrial e para as de desenho industrial, cada um com numeração própria.

Art. 27. Os privilégios que forem concedidos pelo Departamento Nacional da Propriedade Industrial terão a mais ampla divulgação possível, através de publicação no órgão oficial do mesmo Departamento e em outros meios de comunicação, mediante convênios com entidades governamentais ou de classe.
Art. 24. Os objetos a que se referem os privilégios de invenção, desenhos ou modelos industriais, trarão obrigatoriamente, quanto a estes e sempre que possível quanto aos primeiros, em lugar bem visível, as indicações respectivamente: "Privilégio de Invenção no...", ou, abreviadamente, "P.I. no ...", "Desenho Industrial no ...", ou "D.I. no ..., "Modelo Industrial no ...", ou "M.I. no ...".

$\S$ 10 A falta das indicações previstas neste artigo, sempre tolerada em objetos que sejam de dimensões minúsculas ou possam por elas ser prejudicadas em sua estética, não induzirá presunção de má-fé do inventor. § 2ㅇ A aposição de semelhantes indicações em objetos não patenteados importa na presunção de má-fé do inventor, ensejando a aplicação das penalidades em lei.
Art. 28. Se entre a data do depósito do pedido de privilégio e a da expedição da patente houver exploração não autorizada da invenção, por terceiro, ficará êste obrigado a indenizar a titular da patente, 


\begin{tabular}{|c|c|}
\hline & $\begin{array}{l}\text { após a expedição desta, de conformidade com o que fôr } \\
\text { decidido e apurado em ação própria. }{ }^{4}\end{array}$ \\
\hline $\begin{array}{c}\text { CAPÍTULO VIII } \\
\text { DA DURAÇÃo do PRIVILÉGIO DE PATENTE DE INVENÇÃo dE DESENHO } \\
\text { E DE MODÊLO INDUSTRIAL }\end{array}$ & $\begin{array}{c}\text { CAPÍTULO IX } \\
\text { DA DURAÇÃo DOS PRIVILÉGIOS }\end{array}$ \\
\hline $\begin{array}{l}\text { Art. } 25.0 \text { privilégio de patente de invenção, de desenho } \\
\text { ou de modêlo industrial vigorará, desde que pagas as } \\
\text { contribuições devidas regularmente, pelo prazo de vinte } \\
\text { anos contados da data do depósito do pedido de } \\
\text { privilégio ou de quinze, contados da data da concessão, } \\
\text { caso esta ocorra após cinco anos da data do depósito do } \\
\text { pedido. } \\
\S 10 \text { Findo o prazo de vigência da patente, a invenção } \\
\text { cairá automàticamente no domínio público. } \\
\S 2 \text { o As patentes concedidas nos têrmos dêste Código } \\
\text { vigorarão pelo prazo previsto neste artigo, ainda que } \\
\text { extintas ou caducas em estado estrangeiro. }\end{array}$ & $\begin{array}{l}\S 1 \text { o Findo o prazo de vigência do privilégio, o objeto da } \\
\text { patente cairá automàticamente no domínio público. } \\
\S 2 \text { O Os privilégios concedidos nos têrmos dêste Código } \\
\text { vigorarão pelo prazo previsto neste artigo, ainda que } \\
\text { extintos ou caducos os privilégios correspondentes em } \\
\text { Estado estrangeiro. }\end{array}$ \\
\hline \multicolumn{2}{|l|}{$\begin{array}{l}\text { Art. 26. O Govêrno poderá, excepcionalmente e quando } \\
\text { julgar conveniente ao interêsse nacional, "ex officio", ou } \\
\text { à vista de pedido devidamente fundamentado e } \\
\text { comprovado, prorrogar o prazo de vigência do privilégio } \\
\text { até o máximo de cinco anos. }\end{array}$} \\
\hline \multicolumn{2}{|l|}{$\begin{array}{l}\text { Art. 27. Quando os privilégios de patentes de invenção, } \\
\text { de desenhos ou de modelos industriais forem } \\
\text { concedidos em co-propriedade, ou se tornarem } \\
\text { comuns, mediante qualquer título hábil, cada um dos } \\
\text { co-proprietários poderá explorar livremente o objeto da } \\
\text { invenção, observadas as disposições legais. }\end{array}$} \\
\hline CAPÍTULO IX (Omissis) & CAPÍTULO X (Omissis) \\
\hline $\begin{array}{c}\text { CAPÍTULO } X \\
\text { DA TRANSFERÊNCIA DOS PRIVILÉGIOS }\end{array}$ & $\begin{array}{c}\text { CAPÍTULO XI } \\
\text { DA TRANSFERÊNCIA, DA ALTERAÇÃO DE NOME E DA SEDE DOS } \\
\text { TITULARES DOS PEDIDOS DE PRIVILÉGIOS E DAS PATENTES E DOS } \\
\text { CONTRATOS DE LICENÇA PARA A EXPLORAÇÃO DESTAS }\end{array}$ \\
\hline $\begin{array}{l}\text { Art. 29. A propriedade da invenção pode ser transferida } \\
\text { por ato "intervivos" ou em virtude de sucessão legítima } \\
\text { ou testamentária. }\end{array}$ & $\begin{array}{l}\text { Art. 31. A propriedade da invenção pode ser transferida } \\
\text { por ato "inter-vivos" ou em virtude de sucessão } \\
\text { legítima ou testamentária. }\end{array}$ \\
\hline $\begin{array}{l}\text { Art. 30. A transferência far-se-à a título gratuíto ou } \\
\text { oneroso, podendo, ambos os casos, ser total ou parcial. } \\
\text { Parágrafo único. A transferência será total quando } \\
\text { envolver todos os direitos resultantes do privilégio; } \\
\text { parcial, quando compreender somente parte dos } \\
\text { direitos outorgados ou houver restrição quanto ao } \\
\text { tempo de uso ou zona de utilização. }\end{array}$ & $\begin{array}{l}\text { Art. 32. A transferência, seja a título gratuito ou } \\
\text { oneroso, poderá ser total ou parcial. } \\
\text { Parágrafo único. A transferência será total, quando } \\
\text { abranger todos os direitos resultantes do privilégio ou } \\
\text { do pedido de patente ou parcial, quando compreender } \\
\text { sòmente parte dêsses direitos ou houver restrição } \\
\text { quanto ao tempo de uso ou zona de utilização. }\end{array}$ \\
\hline $\begin{array}{l}\text { Art. 31. A anotação da transferência da patente deve ser } \\
\text { requerida ao Diretor-Geral do Departamento Nacional } \\
\text { da Propriedade Industrial, mediante apresentação do } \\
\text { respectivo título e dos instrumentos originais da } \\
\text { transferência ou de suas certidões. } \\
\S 10 \text { A transferência só produzirá efeito, em relação a } \\
\text { terceiros, depois de anotada no Departamento. }\end{array}$ & $\begin{array}{l}\text { Art. 33. A anotação de transferência de patente ou de } \\
\text { pedido deverá ser requerida ao Diretor-Geral do } \\
\text { Departamento Nacional da Propriedade Industrial, } \\
\text { mediante apresentação do respectivo título e dos } \\
\text { instrumentos originais de transferência ou de suas } \\
\text { certidões, e do comprovante do pagamento da taxa } \\
\text { regulamentar. }\end{array}$ \\
\hline
\end{tabular}

\footnotetext{
${ }^{4}$ Ou seja, qualquer reparação fica condicionada à concessão da patente, pois o infrator ficará obrigado a indenizar o titular da patente após a expedição desta.

${ }^{5}$ Texto mais técnico do que o de seu correspondente.
} 
§ 2ㅇ A anotação será feita no registro próprio e averbada na respectiva carta-patente.

$\S$ 3응 Os documentos relativos à transferência ficarão arquivados no Departamento.

$\S$ 4ㅇ A requerimento dos interessados poderão ser fornecidas certidões dos documentos a que se refere o parágrafo anterior.

Art. 32. Será anotada no Departamento Nacional da Propriedade Industrial, à vista de documentos hábeis, qualquer alteração quanto ao nome do proprietário do privilégio. Dêsse ato dar-se-á certidão ao interessado, ficando arquivados os documentos respectivos.

Parágrafo único. Serão igualmente anotados os atos que se refiram à suspensão, limitação ou extinção dos privilégios, por despacho do Diretor-Geral do Departamento, quando os interessados o requererem, juntando documentos hábeis.

Art. 33. A anotação de transferência dos direitos da patente e de alteração do nome do respectivo titular será efetuada dentro de trinta dias da data da publicação do despacho, mediante o pagamento prévio das taxas regulamentares, não comportando oposição ou recurso.
§ 10 A transferência só produzirá efeito em relação a terceiros depois de anotada no Departamento.

$\S 2$ 2 A anotação será feita no registro próprio e averbada na respectiva patente ou no pedido de patente.

§ 3ㅇ Os documentos relativos à transferência ficarão arquivados no Departamento, não cabendo restituição dos mesmos.

$\S$ 4ㅇ A requerimento dos interessados poderão ser fornecidas certidões ou fotocópias autenticadas dos documentos a que se refere o parágrafo anterior, que produzirão os efeitos jurídicos dos originais.

Art. 34. Será anotada no Departamento Nacional da Propriedade Industrial qualquer alteração quanto ao nome ou quanto à sede do titular do privilégio ou do pedido de patente.

Parágrafo único. Serão igualmente anotados os atos que se refiram à suspensão, limitação ou extinção dos privilégios, por despacho de autoridade administrativa ou judiciária; neste último caso, por comunicação da autoridade ou quando os interessados o requererem, juntando documentos hábeis.

Art. 35. A anotação da alteração do nome ou da sede do titular deverá ser requerida ao Diretor-Geral do Departamento Nacional da Propriedade Industrial, mediante apresentação do respectivo título, acompanhado de documentos hábeis e do comprovante do pagamento da taxa regulamentar. Parágrafo único. A anotação será feita no registro próprio e averbada na respectiva patente ou no pedido de patente.

Art. 34. Qualquer pessoa com legítimo interêsse poderá requerer ao Diretor-Geral do Departamento Nacional da Propriedade Industrial a suspensão da anotação de transferência dos direitos da patente, desde que comprove ter iniciado processo judicial de falsidade ou relativo à ineficácia dos atos referentes à anotação de transferência.

$\S 10$ A suspensão a que se refere êste artigo será mantida até a apresentação de certidão de trânsito em julgado da sentença final relativa ao respectivo processo judicial.

$\S$ 2o O cancelamento das anotações, decorrentes de falsidade, não exime os autores ou beneficiários desta,

Art. 36. A anotação de transferência dos direitos de patente ou de pedido de patente e de alteração do nome e da sede do titular será efetuada dentro de sessenta dias da data da publicação do despacho respectivo, não se admitindo qualquer recurso administrativo. 


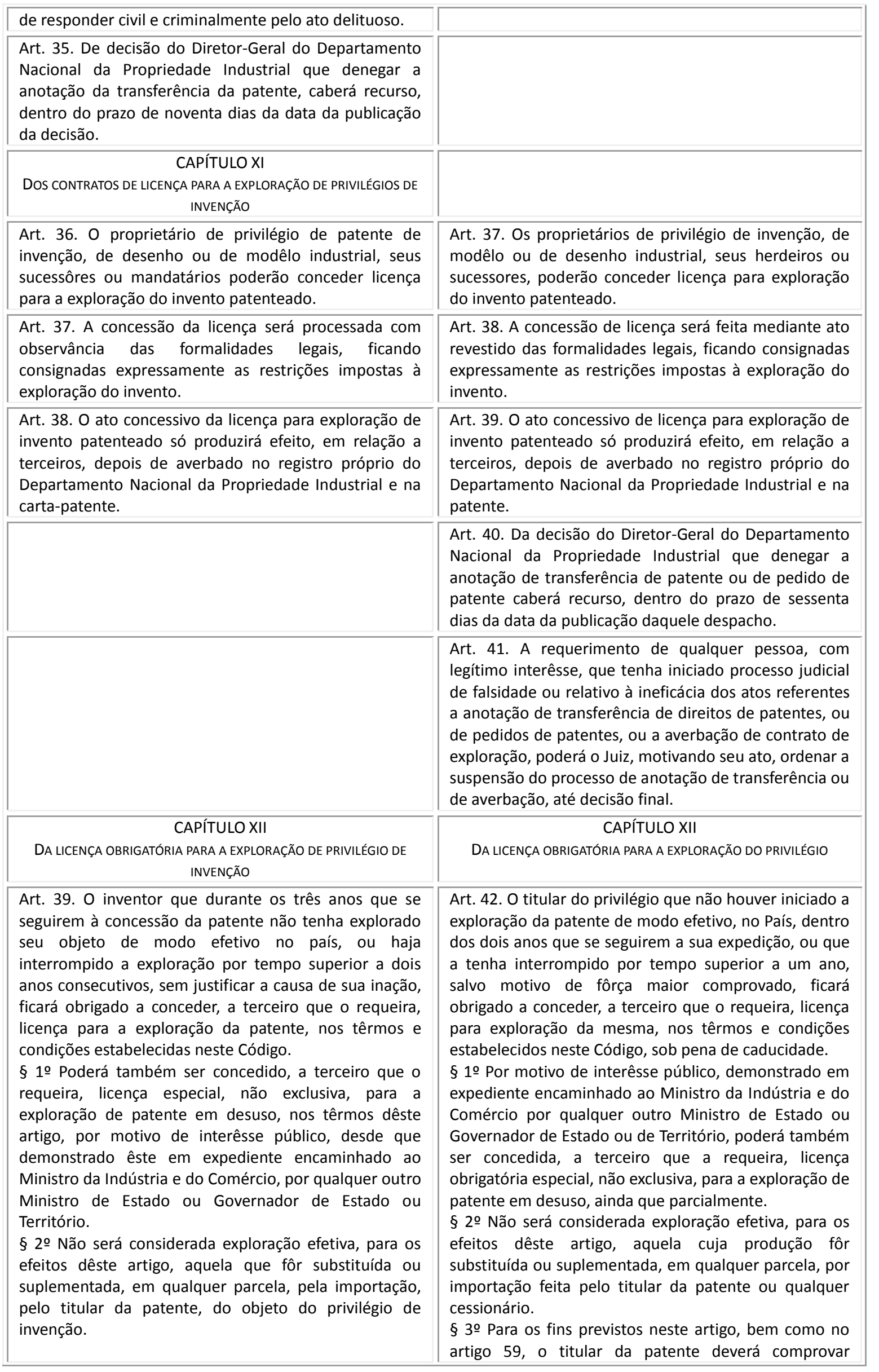


Art. 40. Para verificação do uso efetivo dos privilégios de invenção, o Departamento Nacional da Propriedade Industrial poderá exigir dos respectivos titulares, a partir do terceiro ano da vigência das patentes, que comprovem sua exploração no país ou justifiquem a causa de sua inação.

$\S 1$ 1o Para os fins do disposto neste artigo, o Departamento Nacional da Propriedade Industrial promoverá a notificação do titular da patente, através de publicação no seu órgão oficial.

§ 2ㅇ Não sendo atendida a notificação dentro do prazo de noventa dias, a contar da data da respectiva publicação, ficará liberada a invenção para os efeitos do disposto no art. 39.

Art. 41. Qualquer pessoa que pretender licença para a exploração deverá requerê-la ao Diretor-Geral do Departamento Nacional da Propriedade Industrial, indicando as condições que oferece ao titular da patente e instruindo seu pedido com documentos que comprovem sua idoneidade técnica e financeira.

$\S 1$ 을 Dêse requerimento será dada oficialmente ciência ao titular da patente, marcando-se-lhe o prazo improrrogável de noventa dias, contados da data da publicação do despacho do Diretor-Geral do Departamento que acolher o pedido de licença e determinar a notificação do titular do privilégio para a necessária resposta.

§ 2ㅇ Durante êsse prazo, o Diretor-Geral do Departamento poderá ordenar investigações, perícias, colhêr informações, bem como providenciar tudo quanto, a seu juízo, se faça mister ao esclarecimento da situação da patente e da idoneidade do pretendente à licença.

§ 30 Findo o prazo de noventa dias, na ausência de resposta conclusiva, por parte do titular da patente, poderá o Diretor-Geral do Departamento concedê-la, desde que verificada a idoneidade do pretendente à licença. perante o Departamento Nacional da Propriedade Industrial, dentro dos três primeiros meses seguintes ao terceiro ano de vigência da mesma, e até o terceiro mês de cada ano que se seguir, a exploração efetiva de seu objeto no País, quer diretamente, quer por terceiros autorizados.
Art. 43. Qualquer pessoa que pretender licença obrigatória para a exploração do invento deverá requerê-la ao Diretor-Geral do Departamento Nacional da Propriedade Industrial, indicando as condições que oferece ao titular da patente e instruindo seu pedido com documentos que comprovem sua idoneidade técnica e econômico-financeira.

$\S 1$ 을 Dêse requerimento será oficialmente notificado o titular da patente, marcando-se-lhe o prazo improrrogável de sessenta dias para manifestar-se.

$\S 2$ 2o Findo o prazo do parágrafo anterior, sem manifestação do notificado, entender-se-á aceita a proposta nas condições oferecidas.

$\S$ 3ㅇ No caso de contestação, o Diretor-Geral do Departamento Nacional da Propriedade Industrial deverá ordenar investigações, perícias, colhêr informações, bem como providenciar tudo quanto, a seu juízo, se faça mister ao esclarecimento do assunto e da idoneidade técnica e econômico-financeira do pretendente à licença, para permitir avaliar-se e determinar-se a retribuição a ser estipulada.

$\S 4$ ㅇ Para atender ao disposto no parágrafo anterior o Diretor-Geral do Departamento Nacional da Propriedade Industrial designará uma comissão constituída de três técnicos, a qual deverá apresentar parecer conclusivo dentro de sessenta dias, e, em seguida, decidirá, cabendo recurso ao Ministro da Indústria e do Comércio.

$\S 5$ ㅇ Para constituir a comissão referida no parágrafo quarto poderá o Diretor-Geral valer-se, também, do concurso de técnicos estranhos ao quadro do Departamento Nacional da Propriedade Industrial, mediante o pagamento de "pro-labore", na forma da lei.

Art. 42. No caso de não atender o titular à notificação prevista no $\S 1$ o do art. 40, o Diretor-Geral do Departamento Nacional da Propriedade Industrial poderá deferir a licença solicitada, ouvidos antes dois peritos credenciados pelo Departamento, aos quais cumprirá informar sôbre as condições da proposta de exploração em face do valor industrial da patente. 
Art. 43. Quando o titular da patente, no prazo assinado, apresentar contestação ao pedido de licença de exploração, o Diretor-Geral do Departamento Nacional da Propriedade Industrial submeterá o assunto ao exame de dois técnicos credenciados do Departamento e em seguida resolverá sôbre o pedido.

Art. 44. O detentor da licença de exploração da patente deverá iniciá-la dentro dos seis meses seguintes à data de sua concessão.

Art. 45. Caberá ao titular da patente participação sôbre o valor das vendas ou da utilização do objeto da patente, ficando-Ihe assegurado o direito de fiscalizar a produção e o montante das vendas ou da utilização do invento e exigir a retribuição estipulada.

Parágrafo único. $\mathrm{O}$ disposto neste artigo não prejudicará qualquer acôrdo ou contrato relativo à exploração da patente que porventura hajam celebrado as partes interessadas.

Art. 46. O titular da patente poderá obter o cancelamento da licença de exploração quando provar que o respectivo cessionário deixou de iniciar a exploração do invento dentro do prazo estabelecido no art. 44 ou a interrompeu por prazo superior a um ano ou ainda deixou de atender ao disposto no art. 45

Art. 47. O detentor da licença de exploração do invento fica investido de podêres de representação que the permitam agir administrativamente ou judicialmente em defesa do privilégio de invenção, cabendo ao titular do privilégio os ônus decorrentes dessa representação.

$$
\text { CAPÍTULO XIII }
$$

DA DESAPROPRIAÇÃO DOS PRIVILÉGIOS DE INVENÇÃO

Art. 48. O Govêrno Federal poderá promover, na forma da lei, a desapropriação de qualquer invenção quando os interêsses nacionais exigirem sua vulgarização ou sua exploração exclusiva pelas entidades ou órgãos da administração federal ou de que esta participe.

$\S 1$ 1 A desapropriação decorrerá de proposta do Ministro da Indústria e do Comércio, em face de parecer e avaliação de comissão técnica para êsse fim designada, em cada caso, pelo Diretor-Geral do Departamento Nacional da Propriedade Industrial.

§ 2o A comissão que deverá emitir parecer sôbre a desapropriação será constituída de especialistas sôbre o objeto da invenção, dos quais pelo menos um será técnico credenciado pelo Departamento Nacional da Propriedade Industrial.

§ 3 A constituição da comissão técnica e o estudo da conveniência da desapropriação serão promovidos pelo Diretor-Geral do Departamento, em face de solicitação de qualquer órgão ou entidade da administração pública ou de que esta participe.
(Vide, acima, os §§ 3ㅇ, 4ㅇ e 5ㅇ do art. 43)

Art. 44. 0 detentor da licença obrigatória deverá iniciar a exploração efetiva de seu objeto dentro dos doze meses seguintes à data de sua concessão, não podendo interrompê-la por prazo superior a um ano, sob pena de cancelamento, nos têrmos do artigo 46, salvo motivo de fôrça maior comprovado.

Art. 45. Caberá ao titular da patente o direito de fiscalizar a produção, o montante das vendas e a boa utilização do invento, conforme os têrmos da licença, bem como o de exigir a retribuição estipulada. ${ }^{6}$

Art. 46. O titular da patente poderá obter o cancelamento da licença de exploração, junto ao Departamento Nacional da Propriedade Industrial, quando provar que o cessionário deixou de atender ao disposto nos artigos 44 e 45.

Art. 47. O detentor da licença de exploração do invento ficará investido de podêres de representação que lhe permitam agir administrativa ou judicialmente em defesa do privilégio.

Art. 48. O Govêrno Federal poderá promover, na forma da lei, a desapropriação de qualquer privilégio, quando o interêsse nacional exigir sua vulgarização ou sua exploração exclusiva por entidade ou órgão da administração federal ou de que esta participe.

$\S 1$ 10 A desapropriação decorrerá de proposta do Ministro da Indústria e do Comércio ao Presidente da República, em face de parecer e avaliação de comissão técnica para êsse fim designada, observado, quanto a sua constituição, o disposto nos parágrafos 4 ㅇ e 50 do artigo 43, em cada caso, pelo Diretor-Geral do Departamento Nacional da Propriedade Industrial.

§ 2o A constituição da comissão e o estudo da conveniência da desapropriação serão promovidos pelo Diretor-Geral do Departamento, em face de solicitação de qualquer órgão ou entidade da administração pública ou de que esta participe.

${ }^{6}$ Ambos tratam de direito do inventor ou do titular da patente. Como já se disse, o interesse maior do presente trabalho é sobre o direito do inventor em si, ou o que lhe seja exclusivo. Porém, há na hipótese direito que se origina da exploração alheia forçada. 
$\S 4$ ㅇ Não aceitando o titular da patente o valor
arbitrado, proceder-se-á judicialmente, na forma da lei.

CAPÍTULO XIV
DAS INVENÇÕES OCORRIDAS NA VIGÊNCIA DO CONTRATO DE
TRABALHO

Art. 49. Na vigência do contrato de trabalho, as invenções do empregado, quando decorrentes de sua contribuição pessoal, com a utilização da instalação ou equipamento do empregador, serão de propriedade comum de ambos, em partes iguais.

$\S 1$ 1 Pertencerão ao empregador as invenções realizadas no curso de pesquisa científica ou durante a execução de contratos de trabalho ou locação de serviços em que a atividade inventiva do empregado tenha sido prevista como objeto do contrato.

$\S 2$ 2 Não dispondo o contrato de modo diferente, presume-se que a remuneração do trabalho relativo à invenção compreende-se no salário ou remuneração normal do empregado.

§ 3ㅇ Quando a invenção fôr independente do contrato de trabalho ou da locação de serviço, mas se compreender dentro das atividades do empregador, êste gozará do direito de preferência para explorar a invenção a título exclusivo ou para adquirir a respectiva patente.

$\S 4$ ㅇ No caso do parágrafo anterior, o empregador poderá ainda requerer o privilégio no estrangeiro, desde que assegurada ao empregado remuneração correspondente ao valor da invenção, a ser estipulada pelas partes, levando-se em conta o auxílio que o empregador haja prestado ao empregado para a realização da invenção.

$\S 500$ direito de preferência será exercido no prazo de três meses contados da data da expedição da patente, tornando-se sem efeito se a remuneração ajustada não fôr integralmente paga no prazo e nas condições estipuladas entre empregador e empregado.

$\S 6$ ㅇ Para os efeitos dêste artigo, reputa-se feita durante a vigência do contrato de trabalho ou de locação de serviços a invenção cuja patente fôr requerida pelo empregado durante o ano seguinte à terminação do contrato, salvo ajuste em contrário. ${ }^{7}$
§ 3 Não aceitando o titular da patente o valor arbitrado, proceder-se-á judicialmente, na forma da lei.

DOS INVENTOS OCORRIDOS NA VIGÊNCIA DO CONTRATO DE TRABALHO

Art. 49. Pertencem ao empregador os inventos do empregado realizados durante contrato de trabalho em que a atividade inventiva do assalariado tenha sido prevista ou decorra da própria natureza da atividade contratada.

§ 10 Salvo disposição expressa do contrato, a compensação do trabalho relativo à invenção limita-se ao salário ou à remuneração percebida pelo empregado.

$\S 2$ 2o Para os efeitos dêste artigo, considera-se feita durante a vigência do contrato de trabalho a invenção cuja patente fôr requerida pelo empregado durante o ano seguinte à terminação do contrato, salvo ajuste em contrário.

$\S 3$ Sempre que a patente resultante de contrato de trabalho fôr requerida pelo empregador, esta circunstância e o nome do inventor serão, obrigatòriamente, mencionados no requerimento e na patente.

\begin{tabular}{|l|l|}
\hline \multicolumn{1}{|l|}{$\mid \begin{array}{l}\text { Art. 50. Pertencem ao empregado as invenções que } \\
\text { realizar sem relação com seu contrato de trabalho e } \\
\text { sem qualquer concurso do empregador ou utilização de } \\
\text { instalações ou equipamentos de sua emprêsa. }\end{array}$} \\
\hline $\begin{array}{l}\text { Art. 51. As invenções do empregado não } \\
\text { compreendidas no artigo 49, mas que hajam dependido } \\
\text { de dados, meios e instalações do empregador, serão de } \\
\text { propriedade comum, em partes iguais, garantido ao } \\
\text { empregador o direito exclusivo de licença de } \\
\text { exploração, assegurada ao empregado a remuneração } \\
\text { que fôn ajustada. }\end{array}$ \\
\hline
\end{tabular}

${ }^{7}$ Trata-se de alteração digna de comentário. A regra contida no art. 49 do Código de 67 muda radicalmente no Código de 69. Antes, a propriedade seria comum a ambos, em partes iguais, em princípio. Com a alteração de 1969, os inventos do empregado realizados durante contrato de trabalho passam a pertencer ao empregador, desde que a atividade inventiva do assalariado estivesse prevista ou decorresse da própria natureza da atividade contratada. 
Art. 50. A exploração da invenção, no caso de propriedade comum do empregado e do empregador, caberá a êste, que fica obrigado a promovê-la no prazo de um ano, contado da data da concessão da patente, revertendo, decorrido êsse prazo, em favor do empregado a plena propriedade.
§ 10 A exploração do objeto da patente deverá ser iniciada pelo empregador dentro do prazo de um ano, a contar da data da expedição da patente, sob pena de reverter em favor do empregado a plena propriedade do invento.

§ 2ㅇ O empregador poderá ainda requerer o privilégio no estrangeiro, desde que assegurada ao empregado remuneração correspondente, a ser estipulada.

§ 3 aso não haja acôrdo quanto à remuneração, será ela fixada por arbitramento, mediante requerimento ao Diretor-Geral do Departamento Nacional da Propriedade Industrial, observado, no que couber, o disposto nos artigos 43 a 47.

$\S$ 4ํ Em caso de alienação da patente, terá o empregador preferência, em igualdade de condições.

Art. 51. Na falta de acôrdo entre empregador e empregado, ou surgindo, entre ambos, desentendimentos no curso da exploração da invenção, poderá qualquer dêles requerer judicialmente lhe seja adjudicada a plena propriedade da patente mediante indenização, ao outro, do valor que fôr arbitrado.

Art. 52. Aplica-se o disposto no artigo precedente, salvo estipulação em contrário, à invenções cujas patentes tenham sido requeridas dentro de um ano, a contar da data em que o inventor houver deixado o serviço da emprêsa, quando realizadas durante a vigência do contrato de trabalho.

Art. 53. Sempre que a patente fôr requerida pela emprêsa e resultar de contrato de trabalho será, obrigatòriamente, mencionada essa circunstância, bem como o nome do inventor, no requerimento e na cartapatente.

Art. 54. Aplica-se o disposto neste Capítulo aos empregados das entidades de direito público interno, suas autarquias e sociedades.
(Vide o § 3ㅇdo art. 51, acima.)

(Vide o § 2ㅇ do art. 49, acima.)

(Vide o § 3ㅇ do art. 49, acima.)

Art. 52. Aplica-se o disposto neste Capítulo aos empregados das entidades de direito público interno, suas autarquias e sociedades. ${ }^{8}$

${ }^{8}$ A grafia do texto original foi preservada. 


\section{Quadro Comparativo (parcial) dos Códigos de 1945 e $1971^{1}$}

DECRETO-LEI 7.903, DE 27 DE AGOSTO DE 1945

\section{CódIGO DA PROPRIEDADE INDUSTRIAL}

Art. 1을 Este Código regula os direitos e obrigações concernentes à propriedade industrial; cuja proteção assegura.

Art. 20 A proteção da propriedade industrial, em sua função econômica e jurídica, visa reconhecer e garantir os direitos daqueles que contribuem para o melhor aproveitamento e distribuição de riqueza, mantendo a lealdade de concorrência no comércio e na indústria e estimulando a iniciativa individual, o poder de criação, de organização e de invenção do indivíduo.

Art. 3으 A proteção da propriedade industrial se efetua mediante:

a) a concessão de privilégio de: patentes de invenção, modelos de utilidade desenhos ou modelos industriais, variedades novas de plantas.

b) a concessão de registros de marcas de indústria e de comércio, nomes comerciais títulos de estabelecimento, insígnias, comerciais ou profissionais, expressões ou sinais de propaganda, recompensas industriais.

Art. 4을 As garantias outorgadas por este Código consistem no direito ao uso e exploração exclusivos do respectivo objeto e às medidas de proteção que estatui, sendo concedidas sem prejuízo dos direitos de terceiros.

Art. 5o As disposições deste Código são extensivas aos pedidos de privilégios e registros de marcas diretamente depositados no Brasil, e àqueles que, depositados no estrangeiro, gozem de vantagens asseguradas por tratados ou convenções.

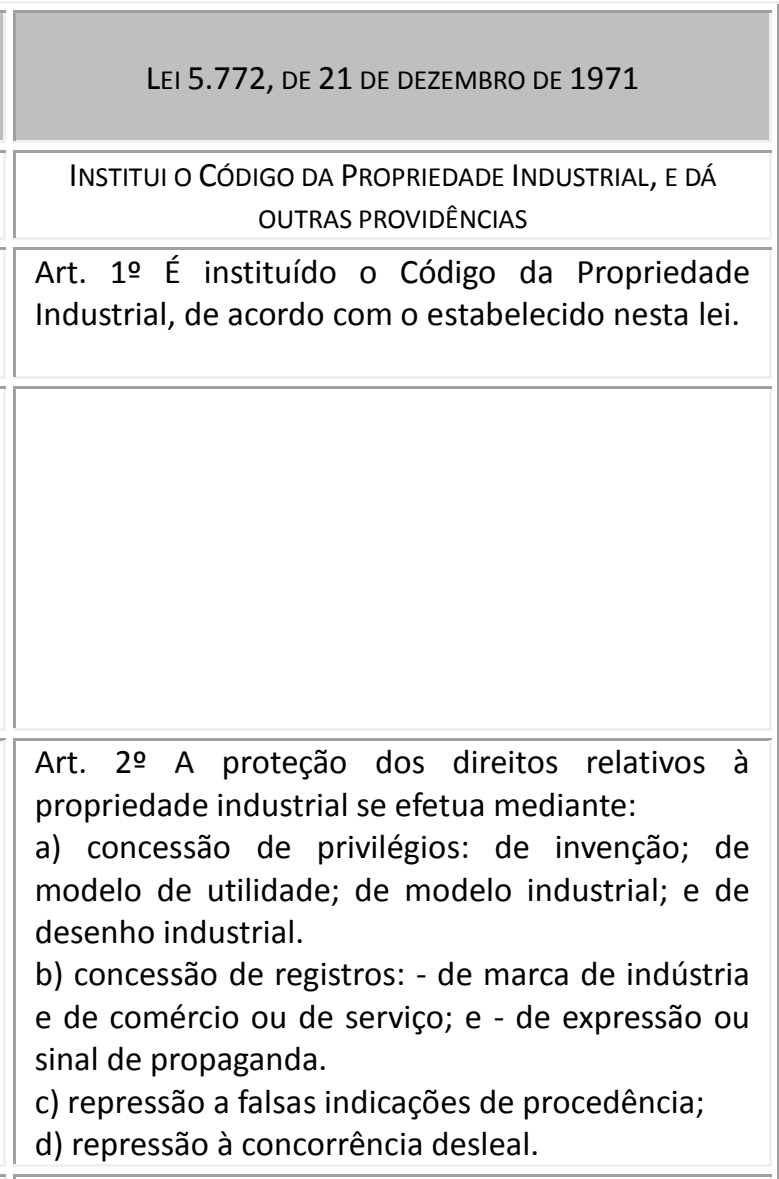

Art. 3ำ As disposições deste Código são aplicáveis também aos pedidos de privilégios e de registros depositados no estrangeiro e que tenham proteção assegurada por tratados ou convenções de que o Brasil seja signatário, desde que depositados no País.

Art. 40 Toda pessoa física ou jurídica domiciliada no Brasil, com legítimo interesse, poderá,

${ }^{1}$ Como estes dois Códigos foram objeto de estudo no Capítulo IV e, também, para que o documento não ficasse deveras extenso, optou-se por não fazer comparação mais ampla do que o estritamente necessário. A intenção, pois, é apenas analisar a estrutura de ambos. Outras diferenças já se anotaram ao longo do trabalho no que eram de interesse e pertinência temática. 


\begin{tabular}{|c|c|}
\hline & $\begin{array}{l}\text { administrativa ou judicialmente, solicitar a } \\
\text { aplicação em igualdade de condições de qualquer } \\
\text { dispositivo de tratados ou convenções a que o } \\
\text { Brasil aderir. }\end{array}$ \\
\hline $\begin{array}{c}\text { TÍTULO I } \\
\text { DOS PRIVILÉGIOS DE INVENÇÃO } \\
\text { CAPÍTULO I } \\
\text { DAS PATENTES DE INVENÇÃO } \\
\text { SECÃO I } \\
\text { DISPOSIÇÕES GERAIS }\end{array}$ & $\begin{array}{c}\text { TÍTULO I } \\
\text { DOS PRIVILÉGIOS } \\
\text { CAPÍTULO I } \\
\text { DISPOSIÇÕES GERAIS } \\
\text { SEÇÃO I } \\
\text { DO AUTOR OU REQUERENTE }\end{array}$ \\
\hline \multirow[t]{2}{*}{$\begin{array}{l}\text { Art. 6o Os autores de invenção suscetível de } \\
\text { utilização industrial terão o direito de obter } \\
\text { patente que Ihes garanta a propriedade e o uso } \\
\text { exclusivo da mesma invenção, de acordo com as } \\
\text { condições estabelecidas neste Código. } \\
\text { Parágrafo único. Consideram-se autores, além dos } \\
\text { inventores, os seus sucessores, sejam pessoas } \\
\text { físicas ou jurídicas de direito público ou privado. }\end{array}$} & $\begin{array}{l}\text { Art. 5o Ao autor de invenção, de modelo de } \\
\text { utilidade, de modelo industrial e de desenho } \\
\text { industrial será assegurado o direito de obter } \\
\text { patente que lhe garanta a propriedade e o uso } \\
\text { exclusivo, nas condições estabelecidas neste } \\
\text { Código. } \\
\S \text { 1o Para efeito de concessão de patente, } \\
\text { presume-se autor o requerente do privilégio. } \\
\S 2 \text { o O privilégio poderá ser requerido pelo autor, } \\
\text { seus herdeiros e sucessores, pessoas jurídicas para } \\
\text { tanto autorizadas, ou eventuais cessionários, } \\
\text { mediante apresentação de documentação hábil, } \\
\text { dispensada a legalização consular no país de } \\
\text { origem, sem prejuízo de autenticação ou exibição } \\
\text { do original, no caso de fotocópia. } \\
\S 3^{\circ} \text { Quando se tratar de invenção realizada por } \\
\text { duas ou mais pessoas, em conjunto, o privilégio } \\
\text { poderá ser requerido por todas ou qualquer delas, } \\
\text { mediante nomeação e qualificação de todas para } \\
\text { ressalva dos respectivos direitos. }\end{array}$ \\
\hline & $\begin{array}{c}\text { SEÇÃO II } \\
\text { DAS INVENÇÕES, DOS MODELOS E DOS DESENHOS } \\
\text { PRIVILEGIÁVEIS }\end{array}$ \\
\hline $\begin{array}{l}\text { Art. 7o É privilegiável no sentido do presente } \\
\text { Código toda invenção considerada nova e } \\
\text { suscetível de utilização industrial. } \\
\text { § } 1 \text { o Considera-se nova a invenção. } \\
\text { a) que até a data do depósito do pedido de } \\
\text { patente não tenha sido, no país, }{ }^{2} \text { depositada ou } \\
\text { patenteada, nem usada publicamente ou descrita } \\
\text { em publicações de modo que possa ser realizada; } \\
\text { b) que até um ano antes do depósito do pedido } \\
\text { de patente, no país, não tenha sido patenteada } \\
\text { no estrangeiro, nem descrita em publicações de } \\
\text { modo que possa ser realizada. } \\
\S 2 \text { o A novidade da invenção não será invalidada } \\
\text { pelas comunicações feitas às sociedades } \\
\text { científicas, associações técnicas profissionais, } \\
\text { legalmente constituídas, ou pela divulgação por }\end{array}$ & $\begin{array}{l}\text { Art. 60 São privilegiáveis a invenção, o modelo de } \\
\text { utilidade, o modelo e o desenho industrial } \\
\text { considerados novos e suscetíveis de utilização } \\
\text { industrial. } \\
\S 1 \text { o Uma invenção é considerada nova quando } \\
\text { não compreendida pelo estado da técnica. }{ }^{3} \\
\S 2 \text { o estado da técnica é constituído por tudo } \\
\text { que foi tornado acessível ao público, seja por uma } \\
\text { descrição escrita ou oral, seja por uso ou qualquer } \\
\text { outro meio, inclusive conteúdo de patentes no } \\
\text { Brasil e no estrangeiro, antes do depósito do } \\
\text { pedido de patente, ressalvado o disposto nos } \\
\text { artigos 7o e } 17 \text {. } \\
\S 3 \text { o Uma invenção é considerada suscetível de } \\
\text { aplicação industrial quando possa ser fabricada ou } \\
\text { utilizada industrialmente. }\end{array}$ \\
\hline
\end{tabular}

\footnotetext{
${ }^{2}$ Princípio da novidade relativa.

${ }^{3}$ Conceito que se inicia legalmente aqui, conforme analisado no Cap. IV.
} 
meio de teses de concursos, exposições ou feiras, oficiais ou oficialmente reconhecidas, desde que o inventor requeira o pedido de privilegio dentro de um ano, contado do dia da realização de qualquer desses fatos.

\begin{tabular}{|c|c|}
\hline & $\begin{array}{l}\text { SEÇÃO III } \\
\text { Da Garantia de Prioridade }\end{array}$ \\
\hline \multirow[t]{2}{*}{ (Vide, abaixo, o art. 9ㅇ) } & $\begin{array}{l}\text { Art. } 7 \text { o Antes de requerida a patente, a garantia de } \\
\text { prioridade poderá ser ressalvada quando o autor } \\
\text { pretenda fazer demonstração, comunicação a } \\
\text { entidades científicas ou exibição do privilégio em } \\
\text { exposições oficiais ou oficialmente reconhecidas. } \\
\S 1 \text { o Apresentado o pedido de garantia de } \\
\text { prioridade, acompanhado de relatório descritivo } \\
\text { circunstanciado, bem como desenhos, se for o } \\
\text { caso, será lavrada a respectiva certidão de } \\
\text { depósito, que vigorará por um ano para os casos } \\
\text { de invenção e por seis meses para os de modelos } \\
\text { ou desenhos. } \\
\S 2^{\circ} \text { Dentro desses prazos deverá ser apresentado } \\
\text { o pedido de privilégio, nas condições e para os } \\
\text { efeitos do disposto neste Código, prevalecendo a } \\
\text { data do depósito a que se refere o parágrafo } \\
\text { anterior. }\end{array}$ \\
\hline & $\begin{array}{l}\text { Art. } 8 \text { o Findos os prazos estabelecidos no } \S 1 \text { o do } \\
\text { artigo } 70 \text {, sem ter sido requerido o privilégio, } \\
\text { extinguir-se-á automaticamente a garantia de } \\
\text { prioridade, considerando-se do domínio público a } \\
\text { invenção, modelos ou desenho. }\end{array}$ \\
\hline $\begin{array}{c}\text { SEÇÃO II } \\
\text { DAS INVENÇÕES NÃO PRIVILEGIÁVEIS }\end{array}$ & $\begin{array}{c}\text { CAPÍTULO II } \\
\text { DAS INVENÇÕES NÃO PRIVILEGIÁVEIS }\end{array}$ \\
\hline 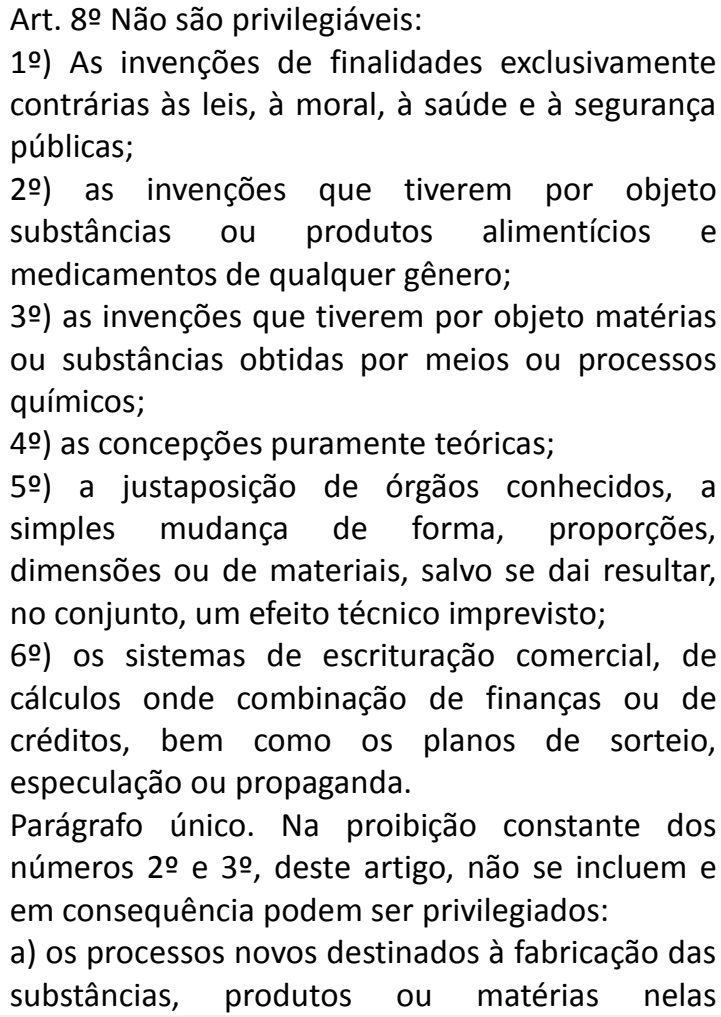 & $\begin{array}{l}\text { Art. 9o Não são privilegiáveis: } \\
\text { a) as invenções de finalidade contrária às leis, à } \\
\text { moral, à saúde, à segurança pública, aos cultos } \\
\text { religiosos e aos sentimentos dignos de respeito e } \\
\text { veneração; } \\
\text { b) as substâncias, matérias ou produtos obtidos } \\
\text { por meios ou processos químicos, ressalvando-se, } \\
\text { porém, a privilegiabilidade dos respectivos } \\
\text { processos de obtenção ou modificação; } \\
\text { c) as substâncias, matérias, misturas ou produtos } \\
\text { alimentícios, químico-farmacêuticos } \\
\text { medicamentos, de qualquer espécie, bem como os } \\
\text { respectivos processos de obtenção ou } \\
\text { modificação; ligas metálicas em geral, } \\
\text { d) as misturas e nas } \\
\text { ressalvando-se, porém, as que, não } \\
\text { compreendidas na alínea anterior, apresentarem } \\
\text { qualidades intrínsecas específicas, precisamente } \\
\text { caracterizadas pela sua composição qualitativa, } \\
\text { definida quantitativamente, ou por tratamento } \\
\text { especial a que tenham sido submetidas; } \\
\text { e) as justaposições de processos, meios ou órgãos } \\
\text { conhecidos, a simples mudança de forma, } \\
\text { proporções, dimensões ou de materiais, salvo se }\end{array}$ \\
\hline
\end{tabular}


mencionados;

b) os produtos novos quando, pelas suas propriedades intrínsecas, análise ou outro exame técnico adequado, revelarem o processo de que são oriundos;

c) as ligas metálicas e misturas com qualidades intrínsecas específicas, perfeitamente caracterizadas pela sua composição. daí resultar, no conjunto, um efeito técnico novo ou diferente, não compreendido nas proibições deste artigo;

f) os usos ou empregos relacionados com descobertas, inclusive de variedades ou espécies de micro organismo, para fim determinado;

g) as técnicas operatórias ou cirúrgicas ou de terapêutica, não incluídos os dispositivos, aparelhos ou máquinas;

h) os sistemas e programações, os planos ou os esquemas de escrituração comercial, de cálculos, de financiamento, de crédito, de sorteios, de especulação ou de propaganda;

i) as concepções puramente teóricas;

j) as substâncias, matérias, misturas, elementos ou produtos de qualquer espécie, bem como a modificação de suas propriedades físico-químicas e seus respectivos processos de obtenção ou modificação, quando resultantes de transformação do núcleo atômico.

SEÇÃO II
DA GARANTIA DE PRIORIDADE

Art. 9o Aquele que, antes de requerer patente, pretenda fazer experiência, ou exibições públicas da invenção, sem prejudicar o requisito da novidade, poderá pedir, no Departamento Nacional da Propriedade Industrial o arquivamento do relatório descritivo da sua invenção, dispensadas as formalidades de exame prévio ou publicação aplicável a tais patentes.

$\S 100$ arquivamento do relatório descritivo, e uma vez deferido pelo Diretor do Departamento somente valera para fins de prioridade, pelo prazo máximo de um ano, contado da data em que tiver sido efetuado.

§ 2을 Findo o prazo de um ano, sem que tenha sido requerida a patente, ou provado haver o inventor explorado, com fins lucrativos, o objeto da invenção, antes ou durante a vigência da garantia de prioridade, deverá esta ser cancelada pelo Diretor do Departamento, "ex officio", ou a requerimento de qualquer interessado, com recurso no prazo de sessenta dias contados da data da publicação do despacho.
(Vide, acima, os arts. 7을 e 8은
(Disposições sobre Modelos de Utilidade e Modelos e Desenhos Industriais - excluídos)

\begin{tabular}{|c|c|}
\hline \multicolumn{2}{|c|}{ (Disposições sobre Modelos de Utilidade e Modelos e Desenhos Industriais - excluídos) } \\
\hline $\begin{array}{c}\text { CAPÍTULO IV } \\
\text { DOS PEDIDOS DE PATENTES DE INVENÇÃO, DE MODELO DE } \\
\text { UTILIDADE E DE DESENHO OU MODELO INDUSTRIAL. }\end{array}$ & $\begin{array}{c}\text { CAPÍTULO IV } \\
\text { DO PEDIDO DE PRIVILÉGIO }\end{array}$ \\
\hline $\begin{array}{l}\text { Art. 17. O pretendente a privilégio de invenção, } \\
\text { modelo de utilidade, desenho ou modelo } \\
\text { industrial, deverá depositar, no Departamento } \\
\text { Nacional da Propriedade Industrial, o seu pedido } \\
\text { acompanhado do relatório descritivo, com os } \\
\text { respectivos desenhos. } \\
\S 1 \text { o O pedido, que deve compreender somente }\end{array}$ & $\begin{array}{l}\text { Art. 14. Além do requerimento, o pedido, que só } \\
\text { poderá se referir a um único privilégio, conterá } \\
\text { ainda: } \\
\text { a) relatório descritivo; } \\
\text { b) reivindicações; } \\
\text { c) desenho, se for o caso; } \\
\text { d) resumo; }\end{array}$ \\
\hline
\end{tabular}


uma invenção, far-se-á em um requerimento dirigido ao Diretor do Departamento, mencionando o nome do inventor, por extenso, a sua nacionalidade, profissão e domicílio; o nome e o endereço do seu procurador, se houver, bem como o título explicativo da invenção, de modo sumário e preciso, concordando com o do relatório.

$\S 2$ 응 0 relatório deverá satisfazer às seguintes condições:

a) ser escrito em português;

b) descrever de maneira precisa e clara a invenção, seu fim e modo de usá-la;

c) ser apresentado em triplicata, datilografado em espaço duplo, de um só lado da folha de papel branco, consistente, nas dimensões de $33 \times 22$ centímetros, sendo seladas as 1 a $s$ e 2 a $s$ vias;

d) não conter emendas, entrelinhas, nem rasuras; e) ser redigido na seguinte ordem:

1으 o cabeçalho, no alto da primeira folha, compreendendo um título que designe sumária e precisamente a natureza e o fim da invenção, excluídas as denominações de fantasia;

2으 a descrição do invento, expondo, pormenorizadamente, sem reservas ou omissões, o problema técnico que o mesmo visa resolver, sua execução e funcionamento;

3 ㅇ, o resumo que defina, com clareza, os pontos constitutivos da invenção, os quais servirão para estabelecer e delimitar os direitos do inventor;

f) conter, no fecho da última folha a data e a assinatura do inventor, ou do seu procurador, rubricadas as demais peças;

$\S 3$ 3 Os desenhos deverão:

a) ser apresentados em triplicata executadas as duas primeiras vias em papel-tela, ou outro julgado equivalente, com tinta preta fixa, sem quaisquer coloridos. e a terceira, por qualquer dos meios usuais; sendo seladas apenas aquelas;

b) ter as dimensões de 33 x 22 centímetros, com moldura traçada em quadro, por linhas singelas, deixando a margem de dois centímetros em toda a extensão;

c) conter, no espaço limitado pela moldura, as figuras em tamanho estritamente necessário, de maneira que se possam distinguir uma das outras e permita o fácil conhecimento das minúcias;

d) adotar numeração, quando as figuras abrangerem varias folhas;

e) indicar as figuras, contendo números seguidos, e) prova do cumprimento de exigências contidas em legislação específica;

f) outros documentos necessários à instrução do pedido.

$\S 10$ O requerimento, o relatório descritivo, as reivindicações, o desenho e o resumo deverão satisfazer as condições estabelecidas pelo Instituto Nacional da Propriedade Industrial. ${ }^{4}$

$\S 2$ 을 As reivindicações, sempre fundamentadas no relatório descritivo, caracterizarão as particularidades do invento, estabelecendo e delimitando os direitos do inventor. ${ }^{5}$

\footnotetext{
${ }^{4}$ Pela primeira vez se adota a postura de maior submissão ao órgão. Também é a primeira indicação do INPI em Códigos.

${ }^{5}$ Abandona-se o sistema detalhista e os detalhamentos seriam a partir de então regulados pelo Instituto.
} 
por meio de setas no sentido da altura do papel, segundo a ordem de sua posição, de modo que concordem com as referências feitas no relatório; f) apresentar uma escala esquemática, excluídas quaisquer denominações, legendas ou menções explicativas;

g) ser datados e assinados pelo inventor, ou seu procurador.

Art. 18. Quando se tratar de pedido de modelo de utilidade, ou de desenho ou modelo industrial, os relatórios, desenhos ou amostras serão regulados de acordo com as instruções aprovadas pelo Ministro do Trabalho, Indústria e Comércio.

\begin{tabular}{|c|c|}
\hline & $\begin{array}{l}\text { Art. 15. Qualquer particularidade do invento, para } \\
\text { ter assegurada proteção isoladamente, deverá ser } \\
\text { requerida em separado, desde que possa ser } \\
\text { destacada do conjunto e não tenha sido, antes, } \\
\text { descrita pormenorizadamente. }\end{array}$ \\
\hline $\begin{array}{c}\text { CAPÍTULO V } \\
\text { DO DEPÓSITO DOS PEDIDOS DE PATENTES DE INVENÇÃO, DE } \\
\text { MODELO DE UTILIDADE E DESENHO OU MODELO INDUSTRIAL. }\end{array}$ & $\begin{array}{c}\text { CAPÍTULO V } \\
\text { Do DEPÓSITO DO PEDIDO DE PRIVILÉGIO }{ }^{6}\end{array}$ \\
\hline $\begin{array}{l}\text { Art. 19. Se os papéis estiverem devidamente } \\
\text { selados, lavrar-se-á um termo assinado pelo } \\
\text { inventor, ou seu procurador, e pelo funcionário } \\
\text { competente. Desse termo constarão a data, com } \\
\text { menção da hora, dia, mês e ano da apresentação } \\
\text { do pedido, o nome do requerente, ou do seu } \\
\text { procurador, podendo dele ser fornecida certidão } \\
\text { ao depositante, mediante o pagamento das taxas } \\
\text { devidas. }\end{array}$ & $\begin{array}{l}\text { Art. 16. Apresentado o pedido, será procedido o } \\
\text { exame formal preliminar e, se devidamente } \\
\text { instruído, será protocolado. } \\
\text { Parágrafo único. Da certidão de depósito, quando } \\
\text { requerida, constarão hora, dia, mês, ano e número } \\
\text { de ordem da apresentação do pedido, título e } \\
\text { natureza do privilégio, indicação de prioridade } \\
\text { quando reivindicada, nome e endereço completos } \\
\text { do interessado e de seu procurador, se houver. }\end{array}$ \\
\hline $\begin{array}{l}\text { Art. 20. Para os efeitos de prioridade, os pedidos } \\
\text { poderão, também, ser depositados nas Delegacias } \\
\text { Regionais do Ministério do Trabalho, Indústria e } \\
\text { Comércio nos Estados, ou em repartição estadual, } \\
\text { a que competir, em virtude de lei, a execução das } \\
\text { funções desempenhadas por aquelas delegacias. } \\
\S 1 \text { o Apresentado o pedido em qualquer das } \\
\text { aludidas repartições com sede no Estado em que } \\
\text { o interessado tiver o seu domicílio, aí será } \\
\text { lavrado, em livro próprio, o termo de depósito, } \\
\text { assinado pelo inventor, ou seu procurador } \\
\text { legalmente habilitado, e pelo funcionário } \\
\text { competente, observadas, nesse ato, as } \\
\text { disposições estabelecidas no art. } 19 \text {. } \\
\S 2 \text { Lavrado o termo de depósito, a Delegacia } \\
\text { Regional, ou a repartição estadual, providenciara } \\
\text { para a remessa dos papéis ao Departamento } \\
\text { Nacional da Propriedade Industrial, dentro do } \\
\text { prazo de cinco dias. contados da data do referido } \\
\text { têrmo. }\end{array}$ & \\
\hline
\end{tabular}

${ }^{6}$ A redação de 1945, ao falar em pedido de "patente", mostrava-se superior. 


\begin{tabular}{|c|c|}
\hline $\begin{array}{c}\text { CAPÍTULO VI } \\
\text { DOS DEPÓSITOS FEITOS NO ESTRANGEIRO }\end{array}$ & $\begin{array}{c}\text { CAPÍTULO VI } \\
\text { Do DEPÓSITO FEITO NO ESTRANGEIRO }\end{array}$ \\
\hline $\begin{array}{l}\text { Art. 21. O inventor que tiver depositado } \\
\text { regularmente em Estado, com o qual o Brasil } \\
\text { mantenha convenção ou tratado, um pedido de } \\
\text { patente de invenção, de modelo de utilidade, ou } \\
\text { de desenho ou modelo industrial, gozará, para } \\
\text { fazer igual pedido no Brasil, do direito de } \\
\text { prioridade pelo prazo estipulado na respectiva } \\
\text { convenção ou tratado. A prioridade em nenhum } \\
\text { caso poderá ser invalidada por fatos ocorridos } \\
\text { durante esse prazo, tais como pedido idêntico, } \\
\text { publicação da invenção, do modelo ou do } \\
\text { desenho, seu uso ou exploração. } \\
\S 10 \text { o prazo de prioridade ficará averbado na } \\
\text { patente, se o interessado, por ocasião de requerê- } \\
\text { la, reivindicar os benefícios decorrentes do } \\
\text { pedido anterior, comprovando-a com o certificado } \\
\text { de deposito no país de origem, ou a respectiva } \\
\text { patente. } \\
\text { § } 20 \text { Fica estabelecido o prazo máximo de três } \\
\text { meses, contados da data do depósito do pedido, } \\
\text { para a apresentação dos comprovantes referidos } \\
\text { no parágrafo anterior. } \\
\S \text { зo Além do Certificado de depósito, poderão ser } \\
\text { exigidos relatórios, desenhos ou outros } \\
\text { documentos que a repartição julgue necessário } \\
\text { ao exame do pedido. }\end{array}$ & $\begin{array}{l}\text { Art. 17. O pedido de privilégio, depositado } \\
\text { regularmente em país com o qual o Brasil } \\
\text { mantenha acordo internacional, terá assegurado } \\
\text { direito de prioridade para ser apresentado no } \\
\text { Brasil, no prazo estipulado no respectivo acordo. } \\
\S 10 \text { Durante esse prazo, a prioridade não será } \\
\text { invalidada por pedido idêntico, sua publicação, } \\
\text { uso, exploração ou concessão da patente. } \\
\text { § } 20 \text { A reivindicação de prioridade deverá ser } \\
\text { comprovada mediante documento hábil do país } \\
\text { de origem, sempre acompanhado de tradução, na } \\
\text { íntegra, contendo o número, a data, o título, o } \\
\text { relatório descritivo e as reivindicações relativas ao } \\
\text { depósito ou à patente. } \\
\text { § } 3 \text { o A apresentação desse comprovante, quando } \\
\text { não tiver sido feita juntamente com a do depósito, } \\
\text { deverá ocorrer até cento e oitenta dias, contados } \\
\text { da data do mesmo depósito, sob pena de perda da } \\
\text { prioridade reivindicada. } \\
\S 4 \text { o No caso de antecipação do exame na forma } \\
\text { do artigo } 18 \text {, o depositante será notificado para } \\
\text { apresentar o citado comprovante dentro de } \\
\text { noventa dias, observado o prazo limite a que se } \\
\text { refere o } \S 30 \text { deste artigo. }\end{array}$ \\
\hline $\begin{array}{c}\text { CAPÍTULO VII } \\
\text { DO EXAME FORMAL E TÉCNICO DOS PEDIDOS DE PATENTES } \\
\text { DE INVENÇÃO, DE MODELO DE UTILIDADE, DE DESENHO E DE } \\
\text { MODELO INDUSTRIAL }\end{array}$ & $\begin{array}{c}\text { CAPÍTULO VII } \\
\text { DA PUBLICAÇÃo E do EXAME DO PEDIDO de PRIVILÉGIO }\end{array}$ \\
\hline $\begin{array}{l}\text { Art. 22. Estando o pedido de privilégio de } \\
\text { invenção, modelo de utilidade, desenho e de } \\
\text { modelo industrial incompleto ou contrário às } \\
\text { normas estabelecidas, será o depositante } \\
\text { oficialmente notificado, a fim de regularizá-lo, } \\
\text { dentro do prazo de noventa dias, sob pena de ser } \\
\text { o processo arquivado. }\end{array}$ & $\begin{array}{l}\text { Art. 18. O pedido de privilégio será mantido em } \\
\text { sigilo até a sua publicação, a ser feita depois de } \\
\text { dezoito meses, contados da data da prioridade } \\
\text { mais antiga, podendo ser antecipada a } \\
\text { requerimento do depositante. } \\
\S 1 \text { a O pedido do exame deverá ser formulado } \\
\text { pelo depositante ou qualquer interessado, até } \\
\text { vinte e quatro meses contados da publicação a } \\
\text { que se refere este artigo, ou da vigência desta lei, } \\
\text { nos casos em andamento. } \\
\S 20 \text { O pedido de privilégio será considerado } \\
\text { definitivamente retirado se não for requerido o } \\
\text { exame no prazo previsto. } \\
\S 3 \text { o O relatório descritivo, as reivindicações, os } \\
\text { desenhos e o resumo não poderão ser } \\
\text { modificados, exceto: } \\
\text { a) para retificar erros de impressão ou } \\
\text { datilográficos; } \\
\text { b) se imprescindível, para esclarecer, precisar ou } \\
\text { restringir o pedido e somente até a data do pedido } \\
\text { de exame; } \\
\text { c) no caso do artigo 19, § 3o. }\end{array}$ \\
\hline
\end{tabular}


Art. 23. Se o pedido de privilégio de invenção ou modelo de utilidade estiver inteiramente em ordem, proceder-se-á, desde logo, ao exame técnico da invenção, podendo-se, quando convier, solicitar audiência de outros serviços técnicos especializados da administração pública, federal, subordinados ou não ao Ministério do Trabalho, Indústria e Comércio, ou de organizações reconhecidas pelo Governo como órgãos de consulta.

$\S 1$ 을 0 exame técnico deverá ser concluído dentro do prazo máximo de:

a) sessenta dias quando se referir a privilegio de invenção: ${ }^{7}$

b) trinta dias quando se tratar de modelos de utilidade. Esses prazos poderão ser prorrogados por motivos justificados, a juízo do Diretor do Departamento Nacional da Propriedade Industrial.

§ 2ㅇ Será publicada, quinzenalmente, no órgão oficial do Departamento Nacional da Propriedade Industrial, uma relação contendo os pedidos de privilegio de invenção e modelos de utilidade apresentados à Repartição, com especificação do objeto.

Art. 24. O encarregado do exame poderá pedir ao inventor ou seu procurador os esclarecimentos que julgar necessários sobre a invenção. bem como novos relatórios descritivos, novos desenhos amostras ou modelo. Desse fato será dada ciência oficialmente ao interessado.

Art. 25. Qualquer que seja a exigência feita em virtude do disposto no art. precedente, deverá ser cumprida dentro do prazo de noventa dias, contados da data da publicação do despacho, sob pena de ser o processo arquivado.
Art. 19. Publicado o pedido de exame, correrá o prazo de noventa dias para apresentação de eventuais oposições, dando-se ciência ao depositante.

§ 1 o 0 exame, que não ficará condicionado a eventuais manifestações sobre oposições oferecidas, verificará se o pedido de privilégio está de acordo com as prescrições legais, se está tecnicamente bem definido, se não há anterioridades e se é suscetível de utilização industrial.

§ 2ㅇ o pedido será indeferido se for considerado imprivilegiável, por contrariar as disposições dos artigos 9. e 13.

§ 3ㅇ Por ocasião do exame, serão formuladas as exigências julgadas necessárias, inclusive no que se refere à apresentação de novo relatório descritivo, reivindicações, desenhos e resumo, desde que dentro dos limites do que foi inicialmente requerido.

§ 4ㅇ№ cumprimento das exigências, deverão ser observados os limites do que foi inicialmente requerido.

§ 50 A exigência não cumprida ou não contestada no prazo de noventa dias acarretará o arquivamento do pedido, encerrando-se a instância administrativa.

$\S 60$ O pedido será arquivado se for considerado improcedente a contestação oferecida à exigência. § 70 Salvo o disposto no § 50 deste artigo, do despacho que conceder, denegar ou arquivar o pedido de privilégio caberá recurso, no prazo de sessenta dias.

Art. 20. Quando se tratar de pedido com reivindicação de prioridade, deverão ser apresentados, sempre que solicitados, as objeções, as buscas de anterioridades ou o resultado dos exames para a concessão de pedido

\footnotetext{
${ }^{7}$ Se os prazos fossem similares a este nos dias de hoje, e fossem cumpridos, o sistema não seria passível de tantas críticas.
} 


\begin{tabular}{|c|c|}
\hline & correspondente em outros países. \\
\hline $\begin{array}{l}\text { Art. 26. Findo o exame técnico serão publicados } \\
\text { os pontos característicos da invenção, para } \\
\text { conhecimento público e apresentação de } \\
\text { oposições, dentro do prazo de } 30 \text { dias, a contar da } \\
\text { data da publicação. }\end{array}$ & (Vide, acima, o art. 19.) \\
\hline $\begin{array}{l}\text { Art. 27. Surgindo oposição de terceiros, será o } \\
\text { pedido submetido a novo exame. } \\
\text { § } \text { 10 Concluída essa formalidade ou não tendo }^{\text {o }} \text { sido apresentadas contestações, será o processo } \\
\text { submetido a despacho do Diretor. } \\
\text { § 20 Do despacho que conceder ou denegar o } \\
\text { privilégio de invenção ou modelo de utilidade, } \\
\text { caberá recurso dentro do prazo de } 60 \text { dias. }\end{array}$ & (Vide, acima, o art. 19, § 70.) \\
\hline $\begin{array}{l}\text { Art. 28. Esgotado o prazo de recurso estabelecido } \\
\text { no artigo anterior e dele não se tendo valido } \\
\text { qualquer interessado serão desde logo expedidos } \\
\text { os atos definitivos. }\end{array}$ & \\
\hline $\begin{array}{l}\text { (Arts. 29-31: Excluídos - tratavam de patente de } \\
\text { desenho e de modelo industrial) }\end{array}$ & \\
\hline $\begin{array}{l}\text { Art. 32. Havendo dúvida, quanto a natureza da } \\
\text { invenção, ou se o exame técnico revelar que o } \\
\text { pedido não pode ser concedido como modelo de } \\
\text { utilidade, desenho ou modelo industrial, mas } \\
\text { como privilégio de invenção, ou vice-versa, o } \\
\text { Diretor do Departamento determinará a } \\
\text { apresentação de novo relatório que classifique } \\
\text { devidamente a invenção, cuja retificação será } \\
\text { publicada, depois da respectiva anotação no } \\
\text { termo de depósito. } \\
\text { Parágrafo único. Tratando-se de processo em grau } \\
\text { de recurso, a modificação prevista neste artigo } \\
\text { somente será realizada mediante a apresentação } \\
\text { de novo pedido. Ficará nesse caso ressalvada a } \\
\text { prioridade, desde que o depósito de novo pedido } \\
\text { se efetue dentro do prazo de noventa dias } \\
\text { contados da data da publicação do despacho } \\
\text { notificativo. }\end{array}$ & \\
\hline $\begin{array}{c}\text { CAPÍTULO VIII } \\
\text { DA EXPEDIÇÃO DA PATENTE DE INVENÇÃO, DE MODELO DE } \\
\text { UTILIDADE, DE DESENHO E DE MODELO INDUSTRIAL }\end{array}$ & $\begin{array}{c}\text { CAPÍTULO VIII } \\
\text { DA EXPEDIÇão DA PATENTE }\end{array}$ \\
\hline $\begin{array}{l}\text { Art. 33. Transitando em julgado o despacho } \\
\text { concessivo, será o inventor oficialmente } \\
\text { notificado, a fim de efetuar o pagamento da taxa } \\
\text { prevista neste Código para expedição da patente } \\
\text { e apresentar o clichê da parte principal da } \\
\text { invenção, medindo } 5 \times 4 \text { centímetros. } \\
\text { Parágrafo único. O pagamento dessa taxa deve ser }\end{array}$ & $\begin{array}{l}\text { Art. } 21 \text { A carta-patente será expedida depois de } \\
\text { decorrido o prazo para o recurso ou, se interposto } \\
\text { este, após a sua decisão. } \\
\text { § } 1 \text { o Findo o prazo a que se refere este artigo, e } \\
\text { não sendo comprovado, em sessenta dias, o } \\
\text { pagamento da retribuição devida, o processo será }\end{array}$ \\
\hline
\end{tabular}

\footnotetext{
${ }^{8}$ Não havia, infelizmente, previsão de novo prazo final. O melhor entendimento é de que deveria ser cumprido o lapso previsto no art. $23, \S 1$. $^{\circ}$, "a".
} 


\begin{tabular}{|c|c|}
\hline $\begin{array}{l}\text { efetuado, dentro do prazo de sessenta dias, sob } \\
\text { pena, de arquivamento do processo. }\end{array}$ & $\begin{array}{l}\text { arquivado, encerrando-se a instância } \\
\text { administrativa. }\end{array}$ \\
\hline $\begin{array}{l}\text { Art. 34. Satisfeito o pagamento da taxa referida } \\
\text { no artigo precedente, será expedida a patente } \\
\text { assinada pelo Diretor do Departamento e pelo } \\
\text { Chefe da Divisão de Privilégios, ressalvando-se os } \\
\text { direitos de terceiros e a responsabilidade do } \\
\text { Governo, quanto à novidade e utilidade da } \\
\text { invenção. } \\
\text { Parágrafo único. Na patente serão mencionados o } \\
\text { nome, nacionalidade, profissão e domicílio do } \\
\text { inventor, nome do procurador, quando houver; o } \\
\text { título da invenção e o prazo de duração, } \\
\text { anexando-se-lhe um das vias do relatório } \\
\text { definitivo e do desenho. }\end{array}$ & $\begin{array}{l}\S \text { 20 Da patente deverão constar o número } \\
\text { respectivo, nome, nacionalidade, profissão e } \\
\text { domicílio do inventor, do seu sucessor ou } \\
\text { cessionário, se houver, o título e natureza do } \\
\text { privilégio e o prazo de sua duração, bem como, } \\
\text { quando for o caso, a prioridade estrangeira, se } \\
\text { comprovada, ressalvando-se os direitos de } \\
\text { terceiros e a responsabilidade do Governo quanto } \\
\text { à novidade e à utilidade, contendo ainda as } \\
\text { reivindicações e os desenhos. }\end{array}$ \\
\hline \multicolumn{2}{|l|}{$\begin{array}{l}\text { (Arts. } 35 \text { a 38: tratam de pedidos de modelo de } \\
\text { utilidade e de desenho e modelo industrial) }\end{array}$} \\
\hline & $\begin{array}{l}\text { Art. 22. Os privilégios concedidos terão ampla } \\
\text { divulgação através de publicação no órgão oficial } \\
\text { do Instituto Nacional da Propriedade Industrial. } \\
\text { Parágrafo único. Para os fins previstos neste artigo, } \\
\text { poderá o Instituto Nacional da Propriedade } \\
\text { Industrial, através de convênios com entidades } \\
\text { governamentais ou de classe, promover a } \\
\text { divulgação por outros meios de comunicação. }\end{array}$ \\
\hline & $\begin{array}{l}\text { Art. 23. A exploração da invenção por terceiro não } \\
\text { autorizado, entre a data do depósito e a da } \\
\text { concessão do privilégio, permitirá ao titular obter, } \\
\text { após a expedição da respectiva patente, a } \\
\text { indenização que for fixada judicialmente. } \\
\text { Parágrafo único. A fixação da indenização } \\
\text { considerará, inclusive, a exploração feita no } \\
\text { período a que se refere este artigo. }\end{array}$ \\
\hline $\begin{array}{c}\text { CAPÍTULO IX } \\
\text { DA DURAÇÃO DO PRIVILÉGIO DE INVENÇÃO, DO MODELO DE } \\
\text { UTILIDADE, DO DESENHO E DO MODELO INDUSTRIAL }\end{array}$ & $\begin{array}{c}\text { CAPÍTULO IX } \\
\text { DA DURAÇÃO DO PRIVILÉGIO }\end{array}$ \\
\hline $\begin{array}{l}\text { Art. 39. O privilégio de invenção vigorará pelo } \\
\text { prazo de quinze anos contados da data da } \\
\text { expedição da patente, findo o qual o invento cairá } \\
\text { no domínio público. }\end{array}$ & $\begin{array}{l}\text { Art. } 24 \text {. O privilégio de invenção vigorará pelo } \\
\text { prazo de quinze anos, o de modelo de utilidade e } \\
\text { o de modelo ou desenho industrial pelo prazo de } \\
\text { dez anos, todos contados a partir da data do } \\
\text { depósito, desde que observadas as prescrições } \\
\text { legais. }^{9} \\
\text { Parágrafo único. Extinto o privilégio, o objeto da } \\
\text { patente cairá em domínio público. }\end{array}$ \\
\hline
\end{tabular}

\footnotetext{
${ }^{9}$ Conforme visto no Cap. IV, trata-se de alteração substancial no sistema até então vigente.
} 
Art. 40. O Governo poderá, excepcionalmente, e quando julgue conveniente aos interesses nacionais, mediante pedido devidamente comprovado, prorrogar o prazo de vigência do privilegio, até cinco anos.

(Arts. 41 e 42: prazos de modelo de utilidade e de desenho e modelo industrial)

Art. 43. Quando as patentes de invenção, modelo industrial, forem concedidas em co-propriedade, ou se tornarem comuns por qualquer título hábil, cada um dos co-proprietários poderá usar livremente o invento respectivo, observadas as disposições legais. 
- APÊNDICE V

\title{
Estatísticas do INPI
}

\author{
V-A
}

Número de concessões e indeferimentos de patentes de invenção por ano

\begin{tabular}{ccccccc}
\hline \multicolumn{5}{c}{ Concessões } & \multicolumn{3}{c}{ Indeferimentos } \\
\hline 2000 & Não residente & Residente & Total & Não residente & Residente & Total \\
2001 & 5500 & 661 & 6161 & 1097 & 459 & 1556 \\
2002 & 2919 & 389 & 3308 & 528 & 195 & 723 \\
2003 & 4054 & 340 & 4394 & 578 & 278 & 856 \\
2004 & 3775 & 401 & 4176 & 661 & 294 & 955 \\
2005 & 1927 & 270 & 2197 & 457 & 191 & 648 \\
2006 & 2201 & 246 & 2447 & 849 & 183 & 1032 \\
2007 & 2263 & 231 & 2494 & 691 & 139 & 830 \\
2008 & 2443 & 197 & 1640 & 660 & 96 & 756 \\
2009 & 2435 & 234 & 2513 & 2004 & 398 & 2402 \\
2010 & 2937 & 340 & 2775 & 1934 & 287 & 2221 \\
2011 & 3065 & 314 & 3251 & 2581 & 430 & 3011 \\
2012 & 2470 & 380 & 3445 & 1611 & 375 & 1986 \\
Total & 37268 & 365 & 2835 & 1117 & 278 & 1395 \\
\hline
\end{tabular}

Fonte: Banco de Dados Estatísticos de Propriedade Intelectual (Badepi) 


\section{V-B}

\section{Patentes por ano de depósito}

Número de concessões de patentes de invenção por ano de depósito

\begin{tabular}{|c|c|c|c|c|c|c|c|c|c|c|c|c|c|}
\hline & 2000 & 2001 & 2002 & 2003 & 2004 & 2005 & 2006 & 2007 & 2008 & 2009 & 2010 & 2011 & 2012 \\
\hline \multicolumn{14}{|l|}{1970} \\
\hline \multicolumn{14}{|l|}{1971} \\
\hline \multicolumn{14}{|l|}{1972} \\
\hline \multicolumn{14}{|l|}{1973} \\
\hline \multicolumn{14}{|l|}{1974} \\
\hline \multicolumn{14}{|l|}{1975} \\
\hline 1976 & & & & & & & & & 1 & & & & \\
\hline \multicolumn{14}{|l|}{1977} \\
\hline \multicolumn{14}{|l|}{1978} \\
\hline 1979 & & & & & & & 3 & & & & & & \\
\hline \multicolumn{14}{|l|}{1980} \\
\hline 1981 & & & & & 1 & 1 & 1 & 1 & & & & & \\
\hline 1982 & & & 1 & & & & & & & & & & \\
\hline 1983 & & & & 2 & & & & & 1 & & & & \\
\hline 1984 & & 1 & 2 & 1 & & & & & & & & & \\
\hline \multicolumn{14}{|l|}{1985} \\
\hline 1986 & 7 & 1 & & & & & & & & & & & \\
\hline 1987 & 5 & 5 & 6 & 3 & & & & & 1 & & & 1 & \\
\hline 1988 & 32 & 10 & 4 & 3 & 1 & 2 & & & & & & & \\
\hline 1989 & 89 & 17 & 7 & 6 & 1 & 2 & & & & & & & \\
\hline 1990 & 297 & 69 & 20 & 19 & 8 & 2 & 1 & & 2 & & & & \\
\hline 1991 & 527 & 91 & 32 & 12 & 5 & 5 & 1 & & & & & & 1 \\
\hline 1992 & 857 & 172 & 87 & 38 & 4 & 6 & 6 & & & & 1 & & \\
\hline 1993 & 1261 & 374 & 246 & 110 & 36 & 10 & 5 & 2 & 2 & & 2 & & \\
\hline 1994 & 1465 & 730 & 438 & 218 & 62 & 26 & 5 & & 3 & 2 & & & \\
\hline 1995 & 1170 & 701 & 1024 & 733 & 302 & 191 & 85 & 30 & 16 & 22 & 22 & 7 & 2 \\
\hline 1996 & 298 & 912 & 1254 & 928 & 516 & 301 & 284 & 113 & 150 & 107 & 53 & 32 & 8 \\
\hline 1997 & 8 & 177 & 1211 & 1104 & 577 & 689 & 431 & 145 & 255 & 287 & 164 & 114 & 34 \\
\hline 1998 & & 3 & 30 & 770 & 620 & 852 & 620 & 348 & 331 & 336 & 322 & 204 & 97 \\
\hline 1999 & 1 & & 9 & 215 & 48 & 317 & 935 & 631 & 615 & 475 & 396 & 313 & 190 \\
\hline 2000 & & & & 10 & 12 & 25 & 110 & 345 & 975 & 675 & 659 & 544 & 240 \\
\hline 2001 & & & & 1 & 3 & 11 & 6 & 25 & 146 & 808 & 1023 & 728 & 472 \\
\hline 2002 & & & & & & 7 & & & 3 & 32 & 532 & 1004 & 754 \\
\hline 2003 & & & & & & & & & 3 & 12 & 35 & 393 & 816 \\
\hline 2004 & & & & & & & & & 6 & 10 & 22 & 77 & 137 \\
\hline 2005 & & & & & & & & & 3 & 4 & 3 & 10 & 52 \\
\hline 2006 & & & & & & & & & & 5 & 8 & 10 & 8 \\
\hline 2007 & & & & & & & & & & & 3 & 5 & 9 \\
\hline 2008 & & & & & & & & & & & & 2 & 12 \\
\hline 2009 & & & & & & & & & & & & & 3 \\
\hline \multicolumn{14}{|l|}{2010} \\
\hline \multicolumn{14}{|l|}{2011} \\
\hline \multicolumn{14}{|l|}{2012} \\
\hline ND & 144 & 45 & 23 & 3 & 1 & 0 & 1 & 0 & 0 & 0 & 6 & 1 & 0 \\
\hline Total & 6161 & 3308 & 4394 & 4176 & 2197 & 2447 & 2494 & 1640 & 2513 & 2775 & 3251 & 3445 & 2835 \\
\hline
\end{tabular}




\section{BIBLIOGRAFIA \\ (Somente das obras consultadas)}

ABRÃO, Eliane Yachouh (org.), Propriedade Imaterial: Direitos Autorais, Propriedade Industrial e Bens de Personalidade, São Paulo, SENAC, 2006.

AlenCAR, José de, A Propriedade, Rio de Janeiro, Garnier, 1883.

AlgArdi, Zara Olivia, Disegno Industriale e Arte Appuicata, Milano, Giuffrè, 1977.

Araujo CARneIro, Heliodoro Jacinto de, Brasil e Portugal, ou Reflecções sobre o Estado Actual do Brasil, Rio de Janeiro, Typographia do Diário, 1822.

- Cartas Dirigidas a S. M. El-Rey D. João VI desde 1817 a cerca do Estado de Portugal e Brazil, e outros mais Documentos Escritos, London, Cox \& Baylis, 1821.

AsCARElli, Tullio, Corso di Diritto Commerciale - Introduzione e Teoria dell'Impresa, 3. ed., Milano, Giuffrè, 1962.

, Teoria della Concorrenza e dei Beni Immateriali: Istituzioni di Diritto Industriale,

3. ed., Milano, Giuffrè, 1960.

, Per uno Studio della Realtà Giuridica Effettuale, Torino, Bono, 1956.

Ascensão, José de Oliveira, Direito Autoral, 2. ed., Rio de Janeiro, Renovar, 2007.

AsSOCIAÇÃO Brasileira dos AgEnTES DA PROPRIEDAdE Industrial, Propriedade Industrial no Brasil: 50 Anos de História, São Paulo, ABAPI, 1998.

AUTERI, Paolo et al., Diritto Industriale, Proprietà Intellettuale e Concorrenza, 3. ed., Torino, Giappichelli, 2009.

AZEVEDo, Philadelpho, Direito Moral do Escriptor, Rio de Janeiro, Alba, 1930.

BAILly, Gustavo Adolpho, Legislação sobre Propriedade Industrial no Brasil, 2. ed., Rio de Janeiro, A. Coelho Branco Filho, 1938.

, Direitos Autorais, São Paulo, Comp. Melhoramento, 1930.

, Protection des Inventions au Brésil, 2. ed., Paris, Giard \& Briere, 1915.

Barbalho (U.C.), João, Constituição Federal Brazileira - Commentarios, Rio de Janeiro, Companhia Litho-Typographia, 1902.

BARbIERI FILHo, Carlo, Disciplina Jurídica da Concorrência - Abuso do Poder 
Econômico, São Paulo, Resenha Tributária, 1984.

Barbosa, Denis Borges, Tratado da Propriedade Intelectual, t. 2, Rio de Janeiro, Lumen Juris, 2013. (org.), Direito da Inovação - Comentários à Lei Federal de Inovação, Incentivos Fiscais à Inovação, Legislação Estadual e Local, Poder de Compra do Estado (Modificações à Lei de Litações), 2. ed., Rio de Janeiro, Lumen Juris, 2011. , Uma Introdução à Propriedade Intelectual, 2. ed., Rio de Janeiro, Lumen Juris, 2003.

, Impasse em Nairóbi: Marcas, Patentes e a nova Ordem Econômica, in JB de 26 de setembro de 1981, Caderno Especial, p. 5.

Barbosa, Pedro Marcos Nunes, Direito Civil da Propriedade Intelectual - o Caso da Usucapião de Patentes, Rio de Janeiro, Lumen Juris, 2012.

Barreto Filho, Oscar, Proteção do Inventor Nacional, In Revista de Direito Mercantil, Industrial, Econômico e Financeiro, Ano XIX, n. 40, São Paulo, RT, 1980, p. 148153.

Barros Monteiro, Washington de, Curso de Direito Civil - Direito das Coisas, Vol. 3, 26 ed., São Paulo, Saraiva, 1988.

BAsso, Maristela, A Extensão da Proteção do Objeto da Patente e os Limites do Princípio da Exaustão de Direitos de Propriedade Intelectual, in Casella, Paulo Borba; Carvalho Ramos, André de (org.), Direito Internacional: Homenagem a Adherbal Meira Mattos, São Paulo, Quartier Latin, 2009, v. 1, p. 137-163.

, O Direito Internacional da Propriedade Intelectual, Porto Alegre, Livraria do Advogado, 2000.

Bastos, Aurélio Wander, Propriedade Industrial: Política, Jurisprudência, Doutrina, Rio de Janeiro, RJ, Liber Juris, 1991.

Ben-Ami, Paulina, Manual de Propriedade Industrial, São Paulo, Promoget, 1983.

Bouche, Nicolas, Le Principe de Territorialité de la Propriété Intellectuelle, Paris, L'Harmattan, 2002.

Braga Junior, Benjamin do Carmo, Patentes de Invenção - Breves Anotações à Lei 3.129 de 14 de Outubro de 1882 e Regulamento n. 8.820 de 30 de Dezembro do Mesmo Ano, com um Completo Formulário, Rio de Janeiro, A Judicial, 1923. 
Bretone, Mario, I Fondamenti del Diritto Romano - le Cose e la Natura, Vol. I, Roma, Laterza, 2001.

Buarque de Holanda, Sérgio, A Herança Colonial - Sua Desagregação, in História Geral da Civilização Brasileira II: o Brasil Monárquico - o Processo de Emancipação, BuARQue DE HolandA, Sérgio (org.), São Paulo, Difusão Europeia do Livro, 1970.

Buys de BARros, Alamiro Bica, Direito Industrial e Legislação do Trabalho, Vol. I, Rio de Janeiro, A. Coelho Branco, 1940.

Capella nascimento, João Paulo, A Natureza Jurídica do Direito sobre os Bens Imateriais, in RABPI 28, p. 23-32.

CARone, Edgard, O Pensamento Industrial no Brasil - 1880-1945, Rio de Janeiro, Difel, 1977.

CARvalho de Mendonça, José Xavier, Tratado de Direito Commercial Brasileiro, 3. ed., Vol. V, Livro III, Parte I, Rio de Janeiro, Freitas Bastos, 1938.

CASAdo Cerviño, Alberto, GATT y Propiedad Industrial: la Tutela de los Derechos de Propiedad Industrial y el Sistema de Resolución de Conflictos en el Acuerdo GATT, Madrid, Tecnos, 1994.

Chavanne, Albert, Burst, Jean-Jacques, Droit de la Propriété Industrielle, 5. ed., Paris, Dalloz, 1998.

CHAVES, Antonio, Direito do Inventor: a Propriedade Científica, Seleções Jurídicas ADV Advocacia Dinâmica, São Paulo, n. 9, p.17-28, set. 1986.

Chisum, Donald S. et al., Principles of Patent Law: Cases and Materials, 3. ed., New York, Foundation Press, 2004.

Conselheiro LafayetTe (Rodrigues Pereira, Laffayete), Direito das Coisas, Vol. I, Brasília, Senado Federal (obra fac-similar), 2004.

CorrêA, Daniel Rocha, Contratos de Transferência de Tecnologia: Fundamentos para o Controle de Práticas Abusivas e Cláusulas Restritivas, Belo Horizonte, Movimento Editorial da Faculdade de Direito da Universidade Federal de Minas Gerais, 2005.

Costa Rodrigues, Clóvis da, A Inventiva Brasileira, Vol. I, Brasília, Instituto Nacional do Livro, 1973. , A Inventiva Brasileira, Vol. II, Brasília, Instituto Nacional do Livro, 1973. 
CunHA, Luis Antonio, O Ensino de Ofícios Artesanais e Manufatureiros no Brasil Escravocrata, 2.ed., Brasília, FLACSO Brasil, 2005.

CRUz FILHo, Murillo, A Entrada do Brasil na Convenção Internacional para a Proteção da Propriedade Industrial - Paris, 1883, in DBB, acesso em 22.10.2013.

DARRAS, Alcide, Du Droit des Auteurs et des Artistes dans les Rapports Internationaux, Paris, Rousseau, 1887.

Di Carnevali, Ugo, Diritto Commerciale e Industriale, Milano, 1981.

Di CATALDO, Vincenzo, L’Originalità dell'Invenzione, Milano, Giuffrè, 1983.

Di Franco, Luigi, Trattato della Proprietà Industriale, Milano, Società Editrice, 1933.

Di MARzo, Salvatore, Istituzioni di Diritto Romano, 3. ed., Milano, Giuffrè, 1941.

Di Sabato, Franco, Lo IUdice, Bruno, Innovazioni Tecnologiche e Diritto di Impresa, 2. ed., Napoli, Morano, 1982.

Domingues, Douglas Gabriel, Privilégios de Invenção, Engenharia Genética $e$ Biotecnologia, Rio de Janeiro, Forense, 1989. , Direito Industrial - Patentes, Rio de Janeiro, Forense, 1980.

EsPínola, Eduardo, Systema do Direito Civil Brasileiro, 3. ed., Vol. I, Rio de Janeiro, Francisco Alves, 1938.

FonseCa Da SILVA, Antonio Carlos, Importação Paralela de Medicamentos, in Revista da Fundação Escola Superior do Ministério Público do Distrito Federal e Territórios, Brasília, Ano 10, Volume 19, jan./jun. 2002, p. 11-27.

Franceschelli, Remo, Trattato di Diritto Industriale - Parte Generale, Milano, Giuffrè, 1973.

Gama Cerqueira, João da, Tratado da Propriedade Industrial, Vol. I, 3. ed., atualizada por Newton Silveira e Denis Borges Barbosa, Rio de Janeiro, Lumen Iuris, 2010. , Vol. II, t. I, 3. ed., atualizada por Newton Silveira e Denis Borges Barbosa, Rio de Janeiro, Lumen Iuris, 2010.

, Vol. II, t. II, 3. ed., atualizada por Newton Silveira e Denis Borges Barbosa, Rio de Janeiro, Lumen Iuris, 2010.

GASPARI, Elio, A Ditadura Escancarada, São Paulo, Companhia das Letras, 2002.

GNOCCHI, Alexandre, Propriedade Industrial e o Ideal Pan-Americano, São Paulo, 
Internacional Propriedade Industrial, 1961. , Propriedade Industrial - Licenças e Royalties no Brasil, São Paulo, RT, 1960.

JENNY, Jean, Brevets d'Inventions: l'Idée Créatrice et le Tour de Main, Lausane, A. Kessler, 1946, p. 21.

Khan, B. Zorina, The Democratization of Invention - Patents and Copyrights in American Economic Development, 1790-1920, New York, Cambridge, 2005.

KoHLER, Josef, Manuale delle Privative Industriali (trad. Ferrucio Foa), Milano, Società Editrice, 1914. , Handbuch des deutschen Patentrechts, Mannheim, Bensheimer, 1900. , Deutsches Patentrecht - systematisch bearbeitet unter vergleichender Berücksichtigung des französischen Patentrechts, Mannheim, Bensheimer, 1878.

LeOnardos, Luiz, Coluna "Propriedade Industrial", Propriedade Industrial $e$ o Desenvolvimento, in JB de 03 e 04.07.1960, Caderno "Indústria". , Coluna "Propriedade Industrial", Requisitos para a concessão, in JB de 26 e 27.06.1960, Caderno “Indústria”.

, Coluna “Propriedade Industrial”, Princípio da Invenção ao Inventor, in JB de 12 e 13.06.1960, Caderno "Indústria".

, Coluna "Propriedade Industrial", in JB de 24 e 25.04.1960 e 01 e 02.05.1960, Caderno "Indústria".

LimA, Heitor Ferreira, História Político-Econômica e Industrial do Brasil, São Paulo, Companhia Editora Nacional, 1970.

LuZzATto, Enrico, Trattato Generale delle Privative Industriali, Vol. I, Milano, Pilade Rocco, 1914.

LoureIro, Francisco Eduardo, A Propriedade como Relação Jurídica Complexa, Rio de Janeiro, Renovar, 2003.

LoureIRO, Luiz Guilherme de A.V., A Lei de Propriedade Industrial Comentada: Lei $n$. 9.279, de 14 de maio de 1996, São Paulo, Lejus, 1999.

Machado, José Mauro Decoussau, Aspectos da Antecipação da Tutela na Propriedade Industrial - Patentes, Desenhos Industriais e Marcas, São Paulo, RT, 2007.

MAINIÉ, Ferdinand, Nouveau Traité des Brevets d'Invention - Commentaire Théorique et 
Pratique de la Loi du 5 Juill, Vol. I, Paris, Maresq, 1896.

Malavota, Leandro Miranda, A Construção do Sistema de Patentes no Brasil: um Olhar Histórico, Rio de Janeiro, Lumen Juris, 2011.

Marquês de São ViCente (Pimenta Bueno, José Antônio), Direito Publico Brazileiro $e$ Analyse da Constituição do Imperio, Rio de Janeiro, Typographia de J. Villeneuve, 1857.

MARTINS, Ana Canas D., Tempo de Dúvidas e Espera, in RHBN 55 (abril de 2010).

Martins, Mônica de Souza N., Entre a Cruz e o Capital: as Corporações de Ofícios no Rio de Janeiro após a Chegada da Família Real (1808-1824), Rio de Janeiro, Garamond, 2008.

MaY, Christopher; Sell, Susan K., Intellectual Property Rights: a Critical History, Boulder, Colo, Lynne Rienner, 2006.

Moreira Alves, José Carlos, Direito Romano, Vol. I, 13. ed., Rio de Janeiro, Forense, 2002.

, Direito Romano, Vol. II, 6. ed., Rio de Janeiro, Forense, 2001.

Motta e Albuquerque, Eduardo da, Patentes Domésticas: Avaliando Estatísticas Internacionais para Localizar o Caso Brasileiro, in Ensaios FEE, Vol. 21, n. 1, Porto Alegre, 2000, p. 119-143.

NAZO, Georgette Nacarato, A Propriedade Intelectual e os TRIPS, Revista de Direito Civil, Imobiliário, Agrário e Empresarial, São Paulo, n. 74, 1995.

Neto, Abílio, CorreiA, Miguel J.A. Pupo, Propriedade Industrial: Legislação Anotada, Lisboa, Petrony, 1982.

Oliveira Lima, Manuel de, D. João VI no Brasil, 3. ed., Rio de Janeiro, TopBooks, 1996. , O Movimento da Independência - 1821-1822, Belo Horizonte, Itatiaia, 1989.

PAES, Paulo Roberto Tavares, Propriedade Industrial, São Paulo, Saraiva, 1982. , Nova lei da Propriedade Industrial: Lei 9.279, de 14.05.1996 - Anotações, São Paulo, RT, 1996.

ParanaguÁ, Pedro; ReIs, Renata, Patentes e Criações Industriais, São Paulo, FGV Jurídica, 2009.

Patrocínio, Daniel Moreira do, Princípio da Exaustão dos Direitos de Propriedade 
Intelectual e a Importação Paralela, in RABPI 84, p. 47-52, 2006.

Peluzo, Cezar (coord.), Código Civil Comentado - Doutrina e Jurisprudência, 2. ed., São Paulo, Manole, 2008.

Penteado, Luciano de Camargo, Direito das Coisas, 2. ed., São Paulo, RT, 2012.

PEREIRA, Luiz Fernando C., Tutela Jurisdicional da Propriedade Industrial: Aspectos Processuais da Lei 9.279/1996, São Paulo, RT, 2006.

PhILIPP, Fernando Eid, Patente de Invenção: Extensão da Proteção e Hipóteses de Violação, São Paulo, Juarez de Oliveira, 2006.

PICARD, Edmond, $O$ Direito Puro, 2. ed. (segunda edição brasileira, sem crédito da tradução), BAHIA, PROGRESSO, 1954.

Pimenta Bueno, José Antônio (v. MARQuÊS DE SÃo VicENTE)

Pimentel, Luiz Otávio, Direito Industrial: Aspectos Introdutórios, Chapecó, Unoesc, 1994.

PinheIro, Paulo Sérgio et al., A Crise dos Anos 20 e a Revolução de 1930, in História Geral da Civilização Brasileira, t. III, o Brasil Republicano, Vol. IX, 8. ed., Rio de Janeiro, Bertrand Brasil, 2006.

Pinheiro de Carvalho, Marieta, A Única Saída, in RHBN 28 (janeiro de 2008), p. 18 e seguintes.

Piola Caselli, Eduardo, Trattato del Diritto di Autore e del Contratto di Edizione nel Diritto Interno Italiano Comparato col Diritto Straniero, Napoli, Eugenio Marghieri, 1927.

Pires de Carvalho, Nuno, 200 Anos do Sistema Brasileiro de Patentes: o Alvará de 28 de abril de 1809, Rio de Janeiro, Lumen Juris, 2009. - A Estrutura do Sistema de Patentes e Marcas - Passado, Presente e Futuro, Rio de Janeiro, Lumen Juris, 2009.

_, As Origens do Sistema Brasileiro de Patentes - O Alvará de 28 de abril de 1809 na Confluência de Políticas Públicas Divergentes - Parte I, in RABPI 91 (NovembroDezembro, 2007), p. 3-28. - As Origens do Sistema Brasileiro de Patentes - O Alvará de 28 de abril de 1809 na Confluência de Políticas Públicas Divergentes - Parte II, in RABPI 92 (Janeiro- 
Fevereiro, 2008), p. 3-20.

Pontes de Miranda, Francisco Cavalcanti, Tratado de Direito Privado - Parte Geral, t. I, Introdução - Pessoas Físicas e Jurídicas, 4. ed., São Paulo, RT, 1974.

, Tratado de Direito Privado - Parte Especial, t. XVI, Direito das Coisas: Propriedade Mobiliária (Bens Incorpóreos) - Propriedade Intelectual - Propriedade Industrial, 2. ed., Rio de Janeiro, Borsoi, 1956.

PoulLLET, Eugène, Traité Théorique et Pratique des Brevets d'Invention et des Secrets de Fabrique, 6. ed., Paris, Marchal \& Godde, 1915.

, Traité Théorique et Pratique des Dessins et Modèles, 5. ed., Paris, Marchal \& Godde, 1911.

Poveda Velasco, Ignacio Maria, Direito, Jurisprudência e Justiça no Pensamento Clássico (Greco-Romano), in Revista da Faculdade de Direito, v. 101, São Paulo, 2006, p. 21-32. _, Os Esponsais no Direito Luso-Brasileiro, São Paulo, Quartier Latin, 2006.

Proner, Carol, Propriedade Intelectual: para uma outra Ordem Jurídica Possível, São Paulo, Cortez, 2007.

Ramella, Agostino, Trattato della Proprietà Industriale, 2. ed., Torino, UTET, 1927.

REQuĩ̃o, Rubens, Curso de Direito Comercial, 25. ed., Vol. I, São Paulo, Saraiva, 2003.

Rodrigues PEREIRA, Laffayete (v. CONSELHEIRo LAFAYETTE).

Romaní, José Luis, Propriedad Industrial y Derecho de Autor: su Regulación Internacional, Barcelona, Bosch, 1976.

Rotondi, Mario, Lezioni di Diritto Industriale, Padova, Cedam, 1933.

RoubIER, Paul, Le Droit de la Propriété Industrielle, Paris, Sirey, 1952-54.

RugGiero, Roberto de, Instituições de Direito Civil (trad. da 6. ed. italiana por Ary dos Santos), Vol. I, São Paulo, Saraiva, 1934.

SANSÓ, Bentio, Estudios de Derecho Industrial, Caracas, Imprenta Universitaria, 1965.

Santoro-Passarelli, Francesco, Dottrine Generali del Diritto Civile, 9. ed., Napoli, Jovene, 1983.

SAunders, Trevor J. (tradução), Aristotle, The Politics, New York, Oxford, 2002. 
Scialoja, Vittorio, Teoria della Proprietà nel Diritto Romano, Spoleto, Are, 1933.

SchegGI, Roberto, Concorrenza Trusts-Crisi: Diritto Industriale e d'Autore, Napoli, Jovene, 1954.

SimÃo FILHO, Adalberto, De LuCCA, Newton (orgs.), Direito Empresarial Contemporâneo, São Paulo, Juarez de Oliveira, 2000.

Silva, Pedro Sousa e, Direito Comunitário e Propriedade Industrial: o Princípio do Esgotamento dos Direitos, Coimbra, Coimbra, 1996.

Silva LisboA, José da (v. Visconde DE CAIRU).

SilveIRA, Newton, Propriedade Intelectual: Propriedade Industrial, Direito de Autor, Software, Cultivares, 4. ed., Barueri, Manole, 2011.

, A Propriedade Intelectual e as Novas Leis Autorais: Propriedade Industrial, Direito de Autor, Software, Cultivares, 2. ed., São Paulo, Saraiva, 1998.

, A Propriedade Intelectual e a Nova Lei de Propriedade Industrial (Lei 9.279, de 14.05.1996), São Paulo, Saraiva, 1996.

, Curso de Propriedade Industrial, 2. ed., São Paulo, RT, 1987.

SilveIRA MARChI, Eduardo Cesar, Guia de Metodologia Jurídica - Teses, Monografias e Artigos, Lecce, Grifo, 2004.

Slemian, Andréa; PIMENTA, João Paulo, Ventos Liberais para o Oeste, in RHBN 86 (novembro de 2012), p 38-41.

STOLFI, Nicola, Proprietà Intellettuale, 2. ed., Vol. I, Torino, UTET, 1915.

Talamanca, Mario, Istituzioni di Diritto Romano, Milano, Giuffrè, 1990.

TeiXeira de Freitas, Augusto, Consolidação das Leis Civis, Brasília, Senado Federal (obra fac-similar), 2003.

Tinoco SoARes, José Carlos, Lei de Patentes, Marcas e Direitos Conexos: Lei 9.279, 14.05.1996, São Paulo, RT, 1997.

, Tratado da Propriedade Industrial - Patentes e seus Sucedâneos, São Paulo, Jurídica Brasileira, 1998.

, Código da Propriedade Industrial: Comentários à Lei 5.772 de 21-12-71 e ao Decreto-Lei 7.903 de 27-08-45, São Paulo, Resenha Tributária, 1974.

Trigo De LOUREIRO, Lourenço, Instituições de Direito Civil Brasileiro, Vol. I, Brasília, 
Senado Federal (obra fac-similar), 2004.

, Instituições de Direito Civil Brasileiro, Vol. II, Brasília, Senado Federal (obra facsimilar), 2004.

Troller, Alois, Immaterialgüterrecht: Patent, Marken, Urheber, Muster und Modell, Wettbewerbsrecht, Basel-Stuttgart, Hebing \& Lichtenhahn, 1959.

Ulho Coelho, Fábio, Manual de Direito Comercial, 16. ed., São Paulo, Saraiva, 2005.

VANDER HaEghen, Georges, Brevets D'Invention, Marques et Modèles, Bruxelles, Ferdinand Larcier, 1928.

Viaro, Mario, La Tutela del Principio Scientifico nel Diritto D’Invenzione, Milano, Giuffrè, 1970.

VIVAnT, Michel (org.), Les Grands Arrêts de la Propriété Intellectuelle, Paris, Dalloz, 2004.

VISCONDE DE CAIRU (Silva Lisboa, José da), Observações sobre a Franqueza da Indústria,

e Estabelecimento de Fábricas no Brasil, Brasília, Senado Federal, 1999 (Reimpressão do Original <obra fac-similar>, Rio de Janeiro, Impressão Régia, 1810).

Watson, Alan, Studies in Roman Private Law, London, Hambledon, 1991. , The Spirit of Roman Law, Athens, University of Georgia, 1995.

Wilken, Patrick, Empire Adrift - The Portuguese Court in Rio De Janeiro, 1808-1821, London, Bloomsbery, 2004.

Zamudio, Teodora, Protección Jurídica de las Innovaciones: Patentes, D.O.V.'s, Genoma Humano, Biodiversidad, Buenos Aires, Ad Hoc, 2001. 


\section{RESUMO}

\section{FundAMENTO DO DiREITO DO INVENTOR: PERSPECTIVA HisTÓRICA BRASILEIRA}

O Brasil foi o quarto país no mundo a ter norma que tratasse sobre direitos de invenção. Além disso, inseriu em seu ordenamento regras de proteção a inventos estrangeiros enquanto ainda não existia uma convenção internacional e reconheceu, constitucionalmente, o direito de propriedade do inventor mais de cinquenta anos antes de essa discussão se iniciar no plano externo conhecido. Destarte, desde muito cedo temas do direito do inventor estiveram presentes na esfera jurídica do país. Ainda, o brasileiro tem por característica a criatividade. Muitos inventos famosos foram criados por nacionais, entre os quais o avião, protótipos da máquina de escrever, sistemas de transmissão de vozes por rádio e o identificador de chamadas telefônicas. Quando se contrapõem as afirmações acima, pode-se chegar à impressão inicial de que o direito do inventor no Brasil se desenvolveu, desde muito cedo, para acompanhar a criatividade brasileira, o que, porém, não corresponde à realidade. O presente trabalho tem por objetivo analisar essa complexa história de desenvolvimento legislativo, pois a precocidade do envolvimento com normas de direito do inventor não necessariamente levou à criação de uma estrutura voltada à proteção dos criadores de invenções técnicas. Procura-se analisar o fundamento do direito do inventor no Brasil, tendo como base a perspectiva histórica das fontes, com o intuito de demonstrar que o que gera direito ao criador de invenções técnicas é o ato-fato da criação. 


\section{ZUSAMMENFASSUNG}

\section{GRUNDLAGEN DES ERFINDUNGSRECHTS: BRASILIANISCHE HISTORISCHE PERSPEKTIVE}

Brasilien war weltweit das vierte Land, das über eine Norm über Erfindungsrecht verfügte. Vor dem Bestehen internationaler Abmachungen fügte es außerdem in seine Vorschriften Schutzregeln für im Ausland gemachte Erfindungen ein. Auf diese Weise waren seit Frühem Themen des Erfindungsrechts im juristischen Bereich des Landes präsent. Darüber hinaus ist Kreativität eine markante Eigenschaft vieler Menschen hierzulande. Von Einheimischen wurden mehrere bekannte Erfindungen gemacht, zum Beispiel, das Flugzeug, erste Exemplare von Schreibmaschinen, die Stimmenübertragung über Rundfunk, das Display zum Anzeigen eingehender Anrufe. Stellt man die oben genannten Aussagen entgegen, so kann man den anfänglichen Eindruck bekommen, dass sich das Erfindungsrecht seit Frühem in Brasilien entwickelte, um mit der einheimischen Kreativität Schritt zu halten, was jedoch nicht unbedingt der Realität entspricht. Die vorliegende Arbeit bezweckt, die komplexe Geschichte der Entwicklung von Gesetzen zu analysieren, denn die Vorzeitigkeit der Beteiligung mit juristischen Normen von Erfindern führte nicht unbedingt zum Entwurf einer an den Schutz von wissenschaftlichen Erfindern gewendeten Struktur. Mit dem Zweck zu erläutern, dass der Ausgangspunkt für die Entwicklung von Schutzgesetzen für Erfinder technischer Gegenstände die Tat des erfinderischen Geistes und dessen durchgeführte Aktionen sind, wird weiterhin versucht, die Grundlagen des Erfindungsrechts in Brasilien aus der Sicht historischer Quellen zu analysieren. 


\section{RIASSUNTO}

\section{IL FONDAMENTO DEL DIRITTO DELL'INVENTORE: LA PROSPETTIVA STORICA BRASILIANA}

Il Brasile è stato il quarto paese del mondo ad avere norme riguradanti i diritti d'invenzione. Inoltre, ha inserito nel suo ordinamento regole di protezione ad inventi stranieri prima dell'esistenza di una convenzione internazionale. Cosicché, da molto presto, temi concernenti al diritto dell'inventore sono stati presenti nella sfera giuridica del paese. Il brasiliano ha la caratteristica della creatività. Molti inventi celebri sono stati creati per nazionali, tra cui l'aereo, prototipi di machine da scrivere, sistemi di trasmissione di voce attraverso la radio, nonché l'identificatore di chiamate telefoniche. Quando si contrappongono queste affermazioni, si può arrivare all'impressione iniziale secondo cui il diritto dell'inventore si è sviluppato, da molto presto, per accompagnare la creatività brasiliana, ciò che non corrisponde però necessariamente alla realtà. Questo lavoro ha per scopo esaminare questa complessa storia dello sviluppo legislativo, poiché il precoce sviluppo di norme sul diritto dell'inventore non ha portato, per forza, alla creazione di una struttura diretta alla protezione dei creatori di invenzione tecniche. Si cerca di analizzare il fondamento del diritto dell'inventore in Brasile, prendendo come base la prospettiva storica delle fonti, com il proposito di dimostrare che ciò che genera diritto al creatore di invenzioni tecniche sia l'atto-fatto della creazione. 